\title{
What we talk about when we talk about Brazilian multinationals : an investigation on Brazilian FDI, economic structure, innovation and the relationship between them
}

Citation for published version (APA):

Pereira de Carvalho, F. (2013). What we talk about when we talk about Brazilian multinationals : an investigation on Brazilian FDI, economic structure, innovation and the relationship between them. [Doctoral Thesis, Maastricht University]. Datawyse / Universitaire Pers Maastricht. https://doi.org/10.26481/dis.20131218fp

Document status and date:

Published: 01/01/2013

DOI:

10.26481/dis.20131218fp

Document Version:

Publisher's PDF, also known as Version of record

Please check the document version of this publication:

- A submitted manuscript is the version of the article upon submission and before peer-review. There can be important differences between the submitted version and the official published version of record. People interested in the research are advised to contact the author for the final version of the publication, or visit the DOI to the publisher's website.

- The final author version and the galley proof are versions of the publication after peer review.

- The final published version features the final layout of the paper including the volume, issue and page numbers.

Link to publication

\footnotetext{
General rights rights.

- You may freely distribute the URL identifying the publication in the public portal. please follow below link for the End User Agreement:

www.umlib.nl/taverne-license

Take down policy

If you believe that this document breaches copyright please contact us at:

repository@maastrichtuniversity.nl

providing details and we will investigate your claim.
}

Copyright and moral rights for the publications made accessible in the public portal are retained by the authors and/or other copyright owners and it is a condition of accessing publications that users recognise and abide by the legal requirements associated with these

- Users may download and print one copy of any publication from the public portal for the purpose of private study or research.

- You may not further distribute the material or use it for any profit-making activity or commercial gain

If the publication is distributed under the terms of Article 25fa of the Dutch Copyright Act, indicated by the "Taverne" license above, 


\section{WHAT WE TALK ABOUT WHEN WE TALK ABOUT BRAZILIAN MULTINATIONALS \\ an investigation on Brazilian FDI, economic structure, innovation and the relationship between them}

Flavia Pereira de Carvalho

UNU-MERIT

Maastricht University 


\section{ISBN 9789461592804}

Copyright: Flavia Carvalho, Maastricht 2013

Layout en druk: Datawyse / Universitaire Pers Maastricht 


\title{
WHAT WE TALK ABOUT WHEN WE TALK ABOUT BRAZILIAN MULTINATIONALS an investigation on Brazilian FDI, economic structure, innovation and the relationship between them
}

\author{
PROEFSCHRIFT \\ ter verkrijging van de graad van doctor \\ aan de Universiteit Maastricht \\ op gezag van Rector Magnificus Prof. Dr. L. L.G. Soete \\ volgens het besluit van het College van Decanen, \\ in het openbaar te verdedigen
}

op woensdag 18 december 2013 om 12:00 uur

door

Flavia Pereira de Carvalho

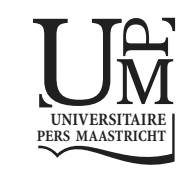


Supervisor

Prof. dr. Geert Duysters

\section{Co-supervisor}

Dr. Ionara da Costa

\section{Assessment Committee}

Prof. dr. Luc Soete (Chair)

Prof. dr. Robin Cowan

Dr. Wilfred Dolfsma (Groningen University, The Netherlands)

Prof. dr. Suzana Rodrigues (Erasmus University, Rotterdam, The Netherlands) 


\section{ACKNOWLEDGEMENT}

It's been a while ago, but I can still remember my first feelings when I arrived, full of bags, to the dream-like city of Maastricht. Chill, was what I felt. And a deep longing for my homely sunshine. "What on Earth could possibly make a Brazilian move from Brazil to come study in a place like that?" was what I got used to hearing from all types of people who came to learn I was Brazilian. The thing is, it had never crossed my mind that kind of change I was going to face, once in the Netherlands.

Despite the lack of sunshine, this country has welcomed me in so many ways I don't even know how to start describing the experience I've had in the 3 years I've lived and studied there, and how greatly those years have changed my life, and who I am.

I believe this is because a place is not just a place, it's a collection of experiences and friendships you make that turns out to be what you carry from living somewhere. And, boy, did Maastricht and UNU-MERIT give me friendships and experiences....the best ones I could dream to find!

It's hard to start...but I guess thanking all of the UNU-MERIT people would be a great start. To the Institute, and to Luc Soete, my deepest thanks, for taking me as a student, for funding my studies, for giving me access to the greatest knowledge, for expanding my world by allowing me to interact with such great minds. I'll be always thankful.

I am immensely grateful for all the people who work or worked at MERIT during my years that helped make the $\mathrm{PhD}$ years so smooth and fun. Those great people are: Eveline (how can I ever thank you enough?), Eric, Ad (I'll always miss you and your books, and fun jokes), Mourik Jan, Herman, Wilma, Monique, Mitie, everyone! In spite of the lack of sun, you've always make days brighter inside the green gates.

I am very grateful for habing the opportunity to learn from amazing professors during my time at Merit. Professors Anthony Bartzokas, Eddie Szirmai, Bart Verspagen, Rene Kemp, Wiebe Bijker, Micheline Goedhuys, Wilfred Dolfsma, Pierre Mohnen, all made a great difference to my knowledge accumulation in those years.

The friends I found inside the green walls, I will take forever in my heart. Dear Nora, I remember so well the first day I saw you and how I thought we could not possibly become friends!!! Thank you so much for proving it wrong, and for giving me the greatest friendship of all times. Thanks for the support in hard times, for the fun in the good ones, for the good music you introduced me to, and for Murakami.

Daniel was another huge friend that I will cherish for a lifetime. Remember the day we carried that silly ugly rug from Brusselssepoort to my place, on foot, under the rain? Friends like you we do not find every day, and I am so grateful for having found you. And Kinga, who came to the group through you and so beautifully gained space between us, I wish you both a lifetime of happiness and love. 
Asel is that kind of friend with that mother talent, she takes care of us, is always there when we need it - and, as if it wasn't enough, there is always good food along with all the love she gives us. Asel and Nico, thanks for being more than friends, thanks for being our family in the Netherlands!

So many dear friends have been there and leaving, each at his time: Fernando, Semih, Radhika, Abraham, Shuan, Lilia, Ezequiel, Luciana, Bilal, Marion, Hezekiah, Ivan, Than, Kirsten Haaland, Zakaria and Natalia,Branka, Lina Salanauskaite. Friends I will always have in my heart.

I have huge debts to the people at FDC who first welcomed me to join them in their studies on the internationalisation of Brazilian firms. My sincere thanks to Paulo Resende, Carlos Arruda, professor Emerson de Almeida, Alvaro Cyrino, Erika Penido and Jase Ramsay, without whom this work would have been way more difficult to complete. My sincere thanks to all the friends I made during my first months at FDC.

Work would have been way tougher and harder to bear, hadn't I found the two most amazing supervisors one could ever find. Dear Geert, you guided me patiently, believed in me, gave space to my academic divagations, you taught me so much more than just the ordinary, you taught seriousness, confidence, competence, integrity. For all this you became a dear friend for life, and there are no ways to thank you enough.

Ionara, you could easily have just been my supervisor. But you went way ahead. You gave me "the problem to solve", you gave me a home in the toughest times - the early times! You became a sister, a friend who also understood my times of distance. You are a brave woman, and your victory over everything that ever tried to defeat you is a lifetime victory, and you deserve every bit of this. I hope that, even far from each other, we can be friends for a lifetime, because you are one of these people who come into our lives to never leave.

I thank my dear parents Ana Maria and Oswaldo for the "spark of life" and for being forever there. I thank my dear sister Camila for the eternal friendship; to my dear little brother Eduardo I owe much more than the beautiful cover for my thesis...

Finally, if there's someone who made every single good thing I ever accomplished in my life... this one is Gustavo. Dear Gu, I came to Europe with your support, and your love kept me strong, even with the distance. You gave me not only love, friendship, helpful revision for this work, you pushed me to work harder, do better, think ahead. I owe everything to you. This work is dedicated to you and Clarice, the truly most marvellous thing that this love could have brought to life.

The title of this thesis is a small homage I needed to pay to Haruki Murakami (who on his turn paid homage to Raymond Carver). He brought fantasy to my $\mathrm{PhD}$ years, and all the years that followed. 


\section{TABLE OF CONTENTS}

Introduction

Foreign Direct Investments from Emerging Countries 13

Analytical Background: FDI and the Internationalisation Strategies of Multinational Firms 15

What We Talk About When We Talk About Brazilian Multinationals 18

Outline of the Thesis $\quad 21$

Chapter 1 - Understanding Brazilian FDI: An Investigation of the Relationship Between Internationalisation and Economic Structure 23

1.1 Introduction 23

1.2 Economic Structure, Outward Direct Investments, and Emerging Countries: A

Conceptual Framework $\quad 25$

$\begin{array}{ll}\text { 1.2.1 Investment Development Path } & 26\end{array}$

1.2.2. Brazilian Investment Development Path $\quad 30$

1.3. Understanding the Brazilian Economy: Development Strategy and Economic Structure 33

1.3.1. Import-Substitution Industrialisation: Local Market, Foreign Multinationals,

the State, and Natural Resources 33

1.3.2. Macroeconomic Context: The Economic Slowdown in the 1980s and the

Liberalisation in the 1990s 36

1.4. Emerging Multinationals and the Role of Policies $\quad 39$

$\begin{array}{ll}\text { 1.4.1. Outward FDI Policies in Korea } & 39\end{array}$

1.4.3. Policies Fostering the Internationalisation of Brazilian Firms 41

1.5. Concluding Remarks 43

APPENDIX: Estimation Results $\quad 46$

\section{Chapter 2 - The Global Players Survey: Methodological Notes and General}

Findings on the Internationalisation Process of Brazilian Firms

2.1. Introduction

2.2. Methodology $\quad 48$

2.3. Characteristics of International Activities of Brazilian Firms 49

2.3.1. Geographic Dispersion of Brazilian Investments $\quad 50$

2.3.2. Modes of Foreign Entry 53

2.3.3. Determinants of Outward Investment $\quad 55$

2.3.4. Technology, Competitiveness, and Internationalisation 57

2.4. Obstacles to Internationalisation: Why do so Few Firms Venture Abroad? 60

2.5. Discussion $\quad 62$

Chapter 3 - What Determines Brazilian FDI? Assessing the Role of Technology in the Recent Wave of Investments from Emerging Multinationals $\quad 65$

3.1. Introduction $\quad 65$

$\begin{array}{ll}\text { 3.2. Theoretical Background } & 67\end{array}$

3.2.1. Determinants of foreign investments by multinational firms $\quad 67$

3.2.2. Determinants of foreign direct investments and location choices $\quad 69$

$\begin{array}{ll}\text { 3.2.3. Brazilian Multinationals } & 71\end{array}$

3.3. Conceptual Framework And Hypotheses $\quad 72$ 
3.4. Data and Methodology $\quad 75$

$\begin{array}{ll}\text { 3.4.1. Variables and Models } & 76\end{array}$

3.5. Results

3.6. Discussion

Chapter 4 - Levels of Internationalisation and firm Advantages: FDI Theory $\begin{array}{lr}\text { Applied To Brazilian Multinationals } & 85\end{array}$

4.1. Introduction $\quad 85$

4.2. Theories of the International Expansion of Firms: Asset Accumulation and
Internationalisation Stages

4.2.1. Eclectic Paradigm $\quad 86$

4.2.2. Uppsala Internationalisation Model $\quad 87$

4.3. Hypotheses

4.4. Internationalisation Process of Brazilian Multinationals 92

4.5. Variables and Model $\quad 94$

$\begin{array}{ll}\text { 4.6. Results } & 97\end{array}$

4.7. Concluding Remarks 98

Chapter 5 - Inovation: Enhancing the Competitiveness of Brazilian Multinationals 101

$\begin{array}{ll}\text { 5.1. Introduction } & 101\end{array}$

5.2. Innovation in Brazil: a portrait from the $3^{\text {rd }}$ Innovation Survey $\quad 102$

5.3. Brazilian Multinationals and Innovative Activities 105

5.3.1. Petrobrás: A Brazilian Multinational Developing Technology at the Frontier 109

5.4. Concluding Remarks 116

Conclusions 117

Main Findings $\quad 117$

Main Contributions 121

Limitations and future research 122

References 123

$\begin{array}{ll}\text { Samenvatting } & 135\end{array}$

$\begin{array}{lc}\text { Curriculum Vitae } & 138\end{array}$ 


\section{LIST OF TABLES}

Table 1.1: FDI stocks of different regions: 1980-2010 24

Table 2.1: Sector distribution of firms in sample 50

Table 2.2: Main acquisitions from Brazilian firms abroad, 2007/2008 55

Table 2.3: International competitive advantages of firms 58

Table 2.4: Main barriers to internationalisation $\quad 61$

Table 3.1 - variables used in the models $\quad 78$

Table 3.2: Correlation Matrix $\quad 79$

Table 3.3: Results of logistic regression 80

Table 3.4: Results from model 5

Table 4.1: Foreign experience and international commitment, by number of firms 93

Table 4.2: Psychic distance and foreign experience, by number of firms 93

Table 4.3: Competitive advantages of Brazilian firms in Global Players sample 94

Table 4.4: Variables used in multinomial logit tests $\quad 95$

Table 4.5: Correlation matrix $\quad 95$

Table 4.6: Results of the multinomial logit model 96

Table 5.1: Absolute R\&D expenditures, 2003-2005 103

Table 5.2: R\&D expenditure by industrial sector and capital ownership 104

Table 5.3: Share of innovative behaviour by firm size 104

\section{LIST OF FIGURES}

Figure 1.1: Investment Development Path 28

Figure 1.2: Brazil inward and outward FDI stocks, 1980-2006 31

Figure 1.3: Brazilian IDP, 1980-2005 32

Figure 1.4: Brazil FDI inward and outward flows, 1975-2011 37

Figure 2.1: Distribution of foreign operations per region $\quad 51$

Figure 2.2: Activities carried out abroad (\%) 53

Figure 2.3: Brazilian investments: Modes of entry by region of destination 54

Figure 2.4: Determinants of internationalisation - number of firms

Figure 2.5: Competitive advantages of Brazilian firms $\quad 59$

\section{LIST OF ABBREVIATIONS}

$\begin{array}{ll}\text { ANP } & \text { Agência Nacional do Petróleo } \\ \text { BNDES } & \text { Banco Nacional de Desenvolvimento Econômico e Social } \\ \text { Bpd } & \text { barrels per day } \\ \text { CSN } & \text { Companhia Siderúrgica Nacional } \\ \text { E\&P } & \text { Exploration \& production } \\ \text { FDC } & \text { Fundação Dom Cabral }\end{array}$


Foreign Direct Investment

GNP

Gross National Product

GDC

Gross Domestic Product

IBGE

Instituto Brasileiro de Geografia e Estatística

IDP

Investment Development Path

INPI

Instituto Nacional de Propriedade Intelectual

ISI

Import-substitution Industrialisation

LLL

Linkage, leverage, learning

MDIC

Ministério do Desenvolvimento, Indústria e Comércio

$\mathrm{MNC}$

Multinational corporation

NOI

Net Outward Investment

OLI (paradigm)

Ownership, location, internalisation

PDP

Política de Desenvolvimento Produtivo

PINTEC

Pesquisa de Inovação Tecnológica

PITCE

$\mathrm{R} \& \mathrm{D}$

Política Industrial, Tecnológica e de Comércio Exterior research and development

SPF

UNCTAD

sistema de produção flutuante

United Nations Committee on Trade and Development 
Begin at the beginning and go on till you come to the end: then stop.

Lewis Carroll

Pain is inevitable. Suffering is optional.

Haruki Murakami 



\section{INTRODUCTION}

\section{Foreign Direct Investments from Emerging Countries}

The share of outward direct investments from emerging economies ${ }^{1}$ in global foreign direct investments (henceforth FDI) increased from 7 percent in 1990 to 15 percent in 2010, growing from USD 145 million to USD 3,1 billion in that period (UNCTAD, 2011). Because of this remarkable growth, they have received huge attention, and a growing number of papers, books, and journal issues have addressed the intriguing questions in this area, especially regarding the nature and patterns of such investments, their determinants, and comparisons with traditional investments from developed economies.

Many recent studies have focused on new global players from China, Taiwan, and India, driven by the impressive acquisitions in the developed world made by some Chinese and Indian firms (such as the acquisition of Land Rover and Jaguar by Tata Motors, of IBM computers by Lenovo, and of Volvo by Geely). Other studies focus on the 'multilatinas', i.e. multinationals originating in Latin American countries, stressing the astounding success achieved by some of them in world markets, and presenting case studies of firms successfully overcoming local constraints.

Studies of emerging multinationals (henceforth MNCs) allow us to understand the differences between these firms and traditional MNCs from developed countries. A particular feature of emerging multinationals is that these firms seem to internationalise faster, without having accumulated a large operational scale or even strong ownership advantages. Moreover, another important aspect is that many firms take the step towards internationalisation to achieve competitive assets not at hand in their domestic markets (Mathews, 2002; Bonaglia et al., 2006). In this regard, local governments and policies that foster internationalisation are considered to play an important role in the process for many countries; China is a good example (Child and Rodrigues, 2005).

It is in the context of increasing attention given to the subject of emerging multinationals that we place our investigation. Brazilian outward investments have boomed in recent years, and although they have existed for at least thirty years, only now do

\footnotetext{
1 The World Investment Report defines "developing and transition economies" as comprising all developing countries plus countries in South-East Europe and the Commonwealth of Independent States (CIS). Occasionally, the term "Third World" is also used to denote these economies. In the thesis, the term "emerging markets" is more narrowly defined and refers to the major sources of FDI from the "South," including Argentina, Brazil, Chile, China, Columbia, Hong Kong (China), India, the Republic of Korea, Malaysia, Mexico, Nigeria, Russia, Singapore, South Africa, Turkey, Taiwan Province of China, Venezuela, which accounted for 90\% of FDI from emerging markets in 2004 (Dunning et al., 2008).
} 
Brazilian multinationals seem to be gaining momentum in the extension of their activities abroad. Over the past few years we have witnessed a growing trend of foreign acquisitions by Brazilian firms, an entry strategy that has gained importance in particular sectors.

It is worth noticing that the subject in question can be analysed through two different perspectives: a microeconomic approach which considers firms as their unit of analysis; and a macroeconomic one, in which FDI from a given economy is the unit of analysis. In general, economists tap macro approaches while management theorists pursue micro-level analyses. But one should remind, as highlighted by Gammeltoft et al. (2010), that "what shows up at the macro level as inward or outward FDI is the aggregation of the activities of thousands of multinationals as they go engaging in international commerce" (Gammeltoft et al., 2010: 98). For this reason this thesis focuses mostly on the multinational firms, their activities, motivations to internationalize, competitive advantages and technological assets, though not losing sight of the macroeconomic structure that influences and is constantly shaped by the movements of these very same firms.

In the discussion of emerging multinationals, two important aspects have been investigated by academics and practitioners: first, whether extant theories can fully explain the evolution of FDI from emerging countries and whether those should be extended or replaced. Second, the factors driving emerging MNCs to foreign markets and the main competitive assets on which internationalisation relies. Whereas definitive conclusions still demand deeper studies, it seems consensual that this new breed of firms requires more recent and the extension of existing theories in order to be fully understood. Because the firms are also the product of the country they originate, they carry their own specificities. In this sense, this thesis expects to contribute to a deeper understanding of Brazilian multinationals and how they differ and resemble both from traditional and other emerging MNCs.

The purpose of our study is to provide a broader picture of outward investment by Brazilian firms. In particular, we want to understand what kinds of characteristics provide Brazilian firms the competitive advantage to enter foreign markets, especially into the more developed ones.

We also want to gain a better perspective of the macroeconomic determinants of the investment pattern. With an in-depth look at Brazilian investments we hope to contribute to the two aspects mentioned above: the usefulness of existing theory and the advantages that apply for MNCs from countries such as Brazil.

While discussing the macroeconomic aspects of FDI, we want to understand the microeconomic drivers of internationalisation. In particular, the thesis addresses the role played in the process of internationalisation by technology and other competitive assets with a knowledge component. Knowledge and technology have long been a central component of internationalisation theories, and they are also used to explain the evolution of firm competitiveness and success. Existing internationalisation theories, as well as recent contributions to the debate on emerging FDI, form the analytical background to this thesis. 


\section{Analytical Background: FDI and the Internationalisation Strategies of Multinational Firms}

FDI has since long been the subject of academic scrutiny. In the past decades several theories trying to understand their patterns and determinants have been developed. Basically, these theories can be divided according to their perspective of the matter: this can be either economic or organizational. Due to the complexity of the internationalisation process, theories with different perspectives are welcome, as they complement each other and enhance their explanatory power.

The economic perspective is represented in this thesis by the Eclectic Paradigm of Internationalisation, developed by John Dunning and which condensates earlier theories (of internalisation and of transaction costs). The organizational perspective is represented by the Uppsala internationalisation theory, which focuses on the characteristics of the firm to explain the internationalisation process, which is expected to be essentially incremental (Johansson \& Vahlne, 1977). The importance of the organisational perspective adopted by the Uppsala model is the fact that it considers aspects of the process of internationalisation that were left aside in the economic approaches to internationalisation (Hemais and Hilal, 2004).

The eclectic paradigm developed by Dunning identifies the drivers of the internationalisation of firms in three sets of advantages: the ownership $(\mathrm{O})$ of specific assets of the firm, which can be tangible (technology) or intangible (brands, managerial capability); the advantages of investing in certain locations (L) that offer superior market or production opportunities and also maximize the chances of the firm realising its ownership advantages; and the advantages of internalising (I) activities and therefore reducing transaction costs, while undertaking transformation processes more efficiently. With these advantages, firms pursue internationalisation according to a range of objectives: market-seeking, natural-resource-seeking, asset-seeking, or efficiencyseeking (Dunning and Lundan, 2008).

The possession of technological advantages has always been considered a key determinant for the growth of a firm, and it is also the main asset sustaining its foreign expansion. Technology has become a more and more crucial component of a successful venture, both domestically and internationally, as we have moved further into the knowledge- and information-intensive era. Knowledge is no longer an asset restricted to high-tech sectors; it plays a crucial role even in traditional industries (Narula and Dunning, 2000).

The Uppsala internationalisation process model also associates foreign expansion with the accumulation of knowledge. The model lies on the assumptions of the theories of organizational behaviour, according to which the firm is composed of cumulative learning processes through a complex network of resources, competences and relationships.

According to Uppsala, internationalisation usually takes place through gradual stages of commitment to the foreign market (Johanson and Vahlne, 1977). The reason is that, in their early years, firms lack the necessary knowledge and information about 
the market, hence incurring higher investment risks. As they accumulate experience, they gain the tools to perform better, and can therefore afford a more significant presence abroad. The geographic range of investments is also expected to widen, as, with experience, psychic distance becomes less of a deterrent in internationalisation plans. The Uppsala internationalisation theory focuses on how firms accumulate the necessary learning for more successful internationalisation. In short, the model has three main guidelines: 1) the lack of knowledge is the main obstacle to internationalisation; 2) the knowledge necessary to internationalise is achieved mainly through the current operations of a firm in a given market; 3 ) the firm internationalises operations gradually, as it accumulates knowledge of the market. The key concepts involved in the process are knowledge and commitment.

It is important to remember that both models have been developed based on evidence from firms originated in developed economies (USA and Sweden) in the 1960s. For this reason, several studies claim the need of a revision of those models or the emergence of a new model to explain foreign investments from emerging markets (Cuervo-Cazurra, 2008).

Further developments to the Uppsala theory considered other forms of knowledge accumulation such as learning through imitation, through the incorporation of people or other organisations - a business network perspective, which includes intra-firm relationships (within subsidiaries) and relationships with external agents (clients, suppliers) (Forsgren, 2001; Johanson and Vahlne, 2009). As these relationships are taken into consideration, the concept of commitment suggested in the Uppsala model now encompasses not just internal resources, but also external resources and capabilities. The market knowledge is not necessarily intrinsic to the firm, but assumes a collective character (Rezende, 2010).

Another theoretical approach that contributes to the development of our analysis from a macroeconomic perspective is a dynamic extension of the OLI paradigm: the investment development path (IDP), "the most generally accepted scholarly explanation for the emergence of new players on the global investment scene" (Dunning et al., 2008). The investment development path was an early attempt to consider the differences in countries' development levels in order to understand their differences in terms of foreign investments. According to the IDP, a country's net outward investment (NOI) position is the outcome of its level of economic development, measured in terms of its GNP per capita (Dunning, 1981; Dunning and Narula, 1996).

In the IDP approach, ownership and locational advantages are connected to the movements of outward/inward FDI. The trajectory of a country's development path is much affected by its inward and outward FDI flows, because such flows influence firm's capabilities at the country level, therefore changing the productivity of the domestic economy as well as the resources and capabilities. On the other hand, locational factors such as the size and resources of a country affect its economic orientation (outward looking and export oriented, or inward looking and import substituting), and therefore have an impact on the levels of outward investment generated by the country (Dunning and Narula, 1996). 
Cuervo-Cazurra (2009) raised an important point associated to the level of development of countries: how structural reforms in developing economies, having changed the economic and institutional environments in these countries, have contributed to trigger the internationalisation of their firms (Cuervo-Cazurra, 2009). According to the author, structural reforms have led to the transformation of locational advantages in those countries and therefore contributed to the development of ownership advantages of firms that enabled them to operate in higher-competition markets (Cuervo-Cazurra, 2009: 149). A similar argument is developed in this thesis when, on chapter 1, we discuss how the inward-looking, import-substitution industrialisation has generated highly protected industries with a low rate of innovativeness; and how the context has changed as, in the 1990s, the Brazilian economy becomes more open to imports and FDI, changing completely the competitive patterns of industries.

Another important perspective to the debate on the internationalisation of firms from developing economies is given by the latecomer firms approach, a discussion carried out by Matthews $(2002,2006)$ in several of his writings. The general assumption is that many of these firms are not waiting to internationalise when they become big and competitive, but, on the opposite, they internationalise in order to grow and gain competitiveness (Matthews, 2004). Having this purpose in mind, these firms establish linkages with global value chains, favoured by a much more interconnected world today than 40 or 50 years ago. Through these links, firms obtain more than just access to key production resources, they tap knowledge, technologies and market access - therefore leveraging from this linkage. Through linkage and leverage, firms accumulate learning - one of the central goals of the internationalisation of these firms. Matthews coined the term LLL to refer to the internationalisation that makes use of these three steps, in an attempt to counterpose it to the established OLI framework that is widely used to explain the internationalisation process. According to the author, the rise of these newcomers and latecomers cannot be explained by the conventional multinational strategies (Matthews, 2002: 5)

Foreign investments by firms from emerging countries have become important in the development agenda of countries in the new era where "innovation-led production is changing the trajectory of global economic development" (Dunning and Narula, 1996: 363). The knowledge-creation process has become less centralised and less often done alone; being close to, or part of, a knowledge and technology network favors the dissemination of firms. For this reason, outward and inward FDI movements have received more attention from governments because of the growing role of multinationals as generators and disseminators of technological development worldwide. Innovation itself is subject to extensive research and is important in the agendas of both entrepreneurs and policymakers.

Guided by the theories exposed above, the thesis proposes to approach internationalisation using both the economic and the organisational framework, also considering foreign investments as a macroeconomic phenomenon. Whereas the object of analysis is the firm, we are also interested in assessing the results of the aggregated phenomenon of internationalisation and its impacts at the country level. 


\section{What We Talk About When We Talk About Brazilian Multinationals}

Brazilian investments abroad have not yet been thoroughly investigated, and for this reason remain an interesting subject of research. A few studies carried out in the 1980s produced a portrait of firms internationalising in order to overcome the economic stagnation of those harsh years (Lall, 1983); more recently, some studies have analysed the patterns of internationalisation of Brazilian firms and their impact on firm performance (Barcellos, 2010). Most works are based on case studies of specific sectors and the factors influencing the strategies of firms (Hemais, 2004; Rocha, 2004). Our study aims to provide a clearer picture of determinants and advantages of the foreign investments of Brazilian firms today, in order to compare recent investments with earlier internationalisation efforts and to determine the ownership advantages that Brazilian firms are using to conquer overseas markets.

Our interest in Brazil comes from the apparent distance between its importance as an emerging market and the rather limited international expansion of its firms. Brazil is an outstanding emerging country (Brainard and Martinez-Dias, 2009) and among the largest economies in the world. It has one of the largest consumer markets in the world and is in continuous (although recently modest) expansion, leaving behind rather quickly and harmlessly the last global economic crisis (Brainard and Martinez-Diaz, 2009; Economist, 2009). Yet, little has been written on the determinants of outward investments from Brazil and their relationship with its economic structure.

Investments by Brazilian firms are clearly expanding, but recent surveys reveal that the main investing sectors today are unchanged from the early years (FDC and CPII, 2007; FDC, 2008), and that most international activities are related to resourceintensive industries. Investments are concentrated in a few firms; the three largest investors (Vale, Petrobrás, and Gerdau) account for three quarters of the assets of the top twenty firms, which total USD 56.4 billion (FDC and CPII, 2007). The top three Brazilian multinationals are also present in the UNCTAD ranking of the top 100 multinationals from emerging markets (UNCTAD, 2006). Brazilian multinationals in the industrial sector account for a much smaller share of total FDI stocks. A crossassessment of the Central Bank database with PINTEC data revealed that only 13.3 percent of total Brazilian capital abroad in 2003 arose from the industrial sector (Arbix et al., 2005).

Existing studies on the internationalisation of Brazilian firms are still few, and most focus on well-known cases of global champions produced by Brazil, such as Embraer, Petrobrás, and Vale (van Agtmael, 2007; Casanova, 2009). Brazilian firms have received less scrutiny because Brazilian outward FDI moved from a leading position in the 1980s, when the first wave of such investments occurred, to an unexceptional performance vis-à-vis other emerging countries, in particular China, in recent years. Nevertheless, many Brazilian firms that have achieved global renown have their successful trajectories deeply rooted in innovation and technological development and are leaders in the national industry. 
Our special interest in Brazilian investments overseas was inspired by an apparent paradox. Brazil is one of the largest economies in the world. It is rich in natural resources to an enviable extent, and is a major emerging country with an extensively developed industrial base. Why does it have relatively few major players in the world economy compared to other emerging economies? Given the country's state of economic development, and the premises of the investment development path (to be analysed in Chapter 1), we raise a question concerning the analysis of Brazilian firms and their foreign investments:

Do Brazilian multinationals fairly represent the country's level of economic development? Why haven't more Brazilian firms internationalised earlier? Why don't we have more global players from Brazil?

The Economist magazine published a series of special reports on Brazil while this thesis was being written. In 2007 it highlighted the country as a "Land of Promise" (Economist, 2007). At the end of 2009 it stated that Brazil had taken off, emphasising that the country's emergence "has been steady, not sudden" (Economist, 2009). In this report, it refers to "a troupe of new and ambitious multinationals" that flourished with the economic openness that occurred in the 1990s as a symbol of the country's success in overcoming a dubious economic past. Articles as such illustrate that the media has long treated Brazil as a promising land, and is still waiting to see the full realisation of the country's potential.

We believe that to understand the drivers of internationalisation for Brazilian firms, it is crucial to link the emergence of such firms to the dynamics of economic development in the country. To the best of our knowledge, so far there are no studies linking economic development to the emergence of multinationals from developing countries and from Brazil in particular. No studies consider the previous development levels and the country's achievement in terms of the international expansion of Brazilian firms. This thesis seeks to fill this gap by looking at the country's level of economic development and economic structure, in order to understand how this structure has produced a specific profile of Brazilian outward FDI.

Having dealt with the macroeconomic aspects of Brazilian FDI, we then switch our attention to the firm level. We investigate the characteristics that relate to innovation and technological capabilities and constitute their Ownership advantages; complementarily, we try to find out whether Brazilian firms are looking for technological or innovative assets abroad and therefore internationalising with this specific purpose. Studies on the recent waves of FDI from emerging countries have frequently dealt with the question of whether such investments have a technology-seeking nature, rather than relying on accumulated technological capabilities as competitive tools to succeed in foreign markets. We therefore pose this question for Brazilian investments. We apply firm-level data from a 2007 survey on large Brazilian firms. The central aspect to be captured is the role of knowledge and innovation in firms' international trajectories, which leads us to other questions that the thesis seeks to answer: 
Why do Brazilian firms decide to internationalise? What are their ownership advantages? What are their liabilities? How does technology (and innovation as its obvious outcome) relate to the emergence of Brazilian Multinationals? How do knowledge and innovation relate to foreign investments by Brazilian firms? What is the role of technological assets in the process of international expansion?

The debate on the role of knowledge and innovation brings the macro and microeconomic perspectives together. A firm's innovation capabilities are the result of earlier choices and accumulated knowledge, which are also influenced by the industrial dynamics that established the country's economic status. The accumulation of technological capabilities and the performance of innovative activities are the main requisites for moving economies and industries forward, and are acknowledged as important determinants of economic development and wealth.

Using firm-level data, the thesis will address questions that are specific to the nature of Brazilian investments overseas: their main drivers, the locations, the types of foreign operation, and how the pattern of recent investment relates to the early investment wave of the 1980s.

A discussion of the specificities of Brazilian FDI can contribute to the debate on to which extent extant theories of international business apply to emerging multinationals and how specific the investments of firms from emerging are. Many of the characteristics of multinationals from emerging countries have changed since the first wave of investment in the early 1980s (Lall, 1983; Wells, 1983). Whereas traditional theory seems to be able to explain their surge, it might be unable to answer specific questions about the advantages that explain firms' international operations (Gammeltoft et al., 2010).

There has been a growing amount of research on emerging FDI, and while some authors suggest that it is a different type of investment (Mathews, 2002, 2006), others explain the phenomenon using the tools applied for the examination of traditional FDI (Dunning et al., 2009; Narula, 2009, 2010). We apply theories, frameworks and paradigms that have been widely discussed to see how they fit to the Brazilian case. This raises further questions:

How specific is the internationalisation of firms from emerging markets? Is it different from traditional multinationals originating from developed locations?

Another aspect related to the specificity of emerging FDI is the role of policies fostering the internationalisation of firms from these regions. We look at two countries: a once-emerging, now developed country, and a prominent emerging economy that seems to be heading for leadership of the economic trajectory of the $21^{\text {st }}$ century. We analyse how the government position towards FDI from domestic firms in these countries has influenced the pattern and results of the internationalisation process. We then compare these cases and Brazil, and discuss how the results found can be linked to such policies. More specifically, we ask whether emerging FDI could do without government policies: 
What is the role of governments and policies to the internationalisation of firms from emerging markets?

Moreover, we look at two other aspects that we expect to be related to internationalisation. We first consider the relationship between certain knowledge-related advantages and the different levels of internationalisation. Departing from the assumption of the Uppsala internationalisation model, of a gradual commitment to foreign markets, we investigate possible firm-specific characteristics, linked to the accumulation of knowledge and technological capabilities, and raise the following question:

Does the possession of certain knowledge-based and technological/innovative capabilities drive Brazilian firms towards more committed levels of internationalisation?

Finally, in Chapter 5 we draw a picture of innovation activities carried out by firms in Brazil, to identify the most innovative sectors of the economy. A vast amount of research has been carried out linking innovative activities of firms (measured by but not restricted to $R \& D$ expenditure) to their competitiveness in both domestic and foreign markets. Innovation is nowadays one of the most valuable assets for firms and countries; it is also widely known that developed countries - through their firms - are where innovation takes place, and that developing countries account for a smaller share of the world's innovations. However, globalization and the expansion of global production networks have extended the role of the latter and innovation has become a more widespread phenomenon. In order to assess the role of innovation in the internationalisation of Brazilian firms, we compare the leading sectors in R\&D expenditure to the sectors where Brazilian FDI is most frequent, in order to try to establish a link. We raise the following question:

What is the role of innovation in the internationalisation process of Brazilian firms?

Our empirical analyses may not provide a definitive answer to all the questions raised. However, they will provide a better understanding of Brazilian outward direct investments and their motivating factors.

\section{Outline of the Thesis}

This thesis is composed of five chapters, in addition to the introduction and conclusion. Each chapter is relatively independent and has specific questions, objectives, methods, and findings. They all come together to address the main enquiries of this research. 
Chapter 1 introduces the macroeconomic dimension of FDI. The chapter assesses the effect of the macroeconomic structure on foreign investment trends for Brazilian firms. It discusses how early industrialisation and liberalisation policies influenced the pattern of FDI from Brazil and therefore played a strong role in the type of multinationals originating there. It also discusses the use of policies at early stages of internationalisation in countries such as Korea, today a developed economy with some of its domestic firms having a remarkable international presence, and how Chinese policies fostered the Go Global strategy. We present recent initiatives in Brazil and discuss the role of policies for creating emerging MNCs.

Chapter 2 introduces the database applied in the empirical models. It highlights the main characteristics of firms that took part in the Global Players survey carried out in Brazil by Fundação Dom Cabral (FDC) in 2007. It discusses the general internationalisation patterns of these firms, their strategies, and the technological capabilities that influence the process.

Chapter 3 presents the first empirical assessment of the Global Players database. We investigate the role that technology plays in the internationalisation of firms. We consider whether Brazilian firms internationalise to obtain technological assets that are not accessible in the local market, or whether they exploit their accumulated technological capabilities overseas. We pay special attention to Brazilian investments directed to developed countries, and how technology relates to this choice of investment location.

Chapter 4 assesses how the competitive advantages of Brazilian firms influence their level of internationalisation, measured as the level of commitment of the firm in the foreign market. In other words, we assess whether the internationalisation of Brazilian firms can be explained as a gradual, evolving process, during which firms accumulate general knowledge and information about foreign markets, and what characteristics are associated with each level.

Chapter 5 discusses the relationship between the internationalisation of Brazilian firms and their innovative activities. This chapter uses a different data source, the Brazilian innovation survey (PINTEC, IBGE), to highlight the most innovative sectors. It also presents a ranking with the most internationalised firms from Brazil. We use this data to suggest a relationship between the two phenomena. The chapter closes with the case of Petrobrás. It provides a good illustration of the role of innovation and technological capabilities in the development of a major global player.

We end the thesis with concluding remarks that present key findings, main limitations, and important lessons learnt from our analysis. 


\section{CHAPTER 1 - UNDERSTANDING BRAZILIAN FDI: AN INVESTIGATION OF THE RELATIONSHIP BETWEEN INTERNATIONALISATION AND ECONOMIC STRUCTURE}

\subsection{Introduction}

Following a trend observed in most dynamic emerging economies, foreign direct investments (henceforth FDI) from Brazilian firms have been going through a process of intense expansion in recent years (van Agtmael, 2007; Goldstein and Pusterla, 2008). Although not a recent movement (the first firms started internationalising in the early 1970s), Brazilian FDI is gaining strength. Outward flows more than doubled in the last decade, revealing Brazilian entrepreneurs' increasing emphasis on expanding markets overseas (Almeida, 2007). According to UNCTAD data, Brazilian FDI stocks reached USD 87 billion in 2006 (see Table 1).

Table 1 shows the evolution of foreign investments by Asian countries such as China, Korea, and Singapore, and Latin American countries such as Brazil, Chile, and Mexico. The numbers evidence a dramatic rise in Asian outward investments as a share of their GDPs. Chile and Mexico have also increased their investments relatively to GDP. Brazil, on the other hand, has moved from a leading position, with foreign investments amounting to $16 \%$ of GDP to a steady position of $9 \%$. Different policies on economic openness, market access to foreign investments, and in some cases a clear effort to foster export performance and internationalisation explain the different evolution of the global enterprises of these countries. 
Table 1.1: FDI stocks of different regions: 1980-2010

\begin{tabular}{|c|c|c|c|c|c|c|c|c|}
\hline \multirow[t]{2}{*}{ Region } & \multicolumn{8}{|c|}{ FDI Stocks } \\
\hline & 1980 & $\begin{array}{l}\% \text { of } \\
\text { GDP }\end{array}$ & 1990 & $\begin{array}{l}\% \text { of } \\
\text { GDP }\end{array}$ & 2006 & $\begin{array}{l}\% \text { of } \\
\text { GDP }\end{array}$ & 2010 & $\begin{array}{l}\% \text { of } \\
\text { GDP }\end{array}$ \\
\hline World & 599,259 & & $1,815,213$ & & $12,474,261$ & & $20,408,257$ & \\
\hline $\begin{array}{l}\text { Developed } \\
\text { countries }\end{array}$ & 526,826 & & $1,669,230$ & & $10,710,199$ & & $16,803,536$ & \\
\hline USA & 215,375 & $7.8 \%$ & 430,521 & $7.5 \%$ & $2,384,004$ & $17.9 \%$ & $4,843,325$ & $33.2 \%$ \\
\hline $\begin{array}{l}\text { Developing } \\
\text { countries } \\
\text { of which }\end{array}$ & 72,433 & & 145,793 & & $1,600,305$ & & $3,131,845$ & \\
\hline Latin America & & & & & & & & \\
\hline Argentina & 5970 & $7.8 \%$ & 6057 & $4.3 \%$ & 24,047 & $11.2 \%$ & 29,841 & $8.1 \%$ \\
\hline Brazil & 38,545 & $16.4 \%$ & 41,044 & $8.9 \%$ & 87,049 & $8.0 \%$ & 180,949 & $8.7 \%$ \\
\hline Chile & 885 & $3.2 \%$ & 1149 & $3.6 \%$ & 26,787 & $18.2 \%$ & 49,838 & $23.4 \%$ \\
\hline Mexico & 1632 & $0.8 \%$ & 2672 & $1.0 \%$ & 35,144 & $3.7 \%$ & 66,152 & $6.4 \%$ \\
\hline Asia & & & & & & & & \\
\hline China & 44 & $0.02 \%$ & 4455 & $1.2 \%$ & 73,330 & $2.7 \%$ & 297,600 & $5.0 \%$ \\
\hline India & 78 & $0.04 \%$ & 124 & $0.04 \%$ & 12,964 & $1.4 \%$ & 92,407 & $5.4 \%$ \\
\hline Hong Kong & 148 & $0.5 \%$ & 11,920 & $15.5 \%$ & 27,768 & $14.6 \%$ & 948,494 & $422.6 \%$ \\
\hline Korea & 127 & $0.2 \%$ & 2301 & $0.9 \%$ & 21,497 & $2.3 \%$ & 138,984 & $13.7 \%$ \\
\hline Singapore & 623 & $5.3 \%$ & 7808 & $21.6 \%$ & 56,755 & $40.9 \%$ & 300,010 & $143.7 \%$ \\
\hline
\end{tabular}

This chapter looks at foreign investments by Brazilian firms from a macroeconomic perspective, to answer one of the questions raised by the thesis: are Brazilian multinationals a reflection of the country's level of development, of its prominence as a leading emerging market and one of the largest economies of the world? Why is Brazil lagging behind in the number of global players when compared to Asian countries?

The main purpose of the analysis is to provide the background for the subsequent analysis of firm-level foreign investments from Brazil. This background consists of using the investment development path to understand how the change in the economic structure of the country has produced a specific set of global champions.

We apply the framework developed by Dunning (1981) to analyse the macroeconomic aspects of Brazilian FDI. The investment development path (henceforth IDP) synthesises the idea of a dynamic relationship between outward and inward investment levels and the level of development of a given country. As the economy develops, a range of factors (including inward FDI levels) leads to a redesign of the nature and volume of inward and outward investment flows.

As a first step we apply the IDP framework to a thirty-year timeframe to assess the dynamics of net outward FDI vis-à-vis the evolution of the GNP per capita. The second step is to look at structural economic factors to understand how they might 
have influenced the positioning of the country along the IDP curve during the period under study.

Finally, we make a brief exposition of the different approaches of some emerging and recently developed countries regarding the internationalisation of domestic firms. We consider the different policies carried out in each country and the results achieved. National policies have become a central feature in the discussion of emerging FDI, because they are increasingly viewed as important in shaping home-country determinants of competitiveness. We discuss China, Korea, and Brazil. We emphasise the increasing role of government policies in determining the status of a country regarding its inward and outward FDI, to answer the associated question raised in this thesis.

This chapter is structured as follows. The next section presents a framework in which economic structure is directly linked to the pattern of foreign investments. The investment development path is presented as a starting framework for the analysis of the Brazilian case. We review the debate on FDI and emerging economies, focusing on the investment development path. Section 1.3 highlights important aspects of the economic structure and macroeconomic evolution of Brazil in the last three decades, aiming to explain why the country has held more or less the same position in the IDP curve throughout that period. Section 1.4 briefly discusses the internationalisation policies carried out in Korea, China, and Brazil. The final section provides concluding remarks and reflections.

\subsection{Economic Structure, Outward Direct Investments, and Emerging Countries: A Conceptual Framework}

The rise of FDIs from developing countries led to a series of theories explaining the phenomenon by stressing the differences between these FDIs and traditional investments from advanced economies (Dunning et al., 2007). Some important studies analysed the investments in depth and proposed a new or complementary theory. Notable examples are Wells' application of the product life cycle (Wells, 1983); Lall's theory of localised technological change (Lall, 1983); and Dunning's investment development path (Dunning, 1981). The literature on traditional FDI, i.e. FDI by firms from developed economies, suggests that firms invest abroad based on 'specific advantages', which are either country-specific (especially natural assets) or firm-specific (created assets). As a country evolves economically, firms' competitive advantages tend to evolve from natural assets to created assets.

Broadly speaking, early theories on emerging FDI extended the approaches developed to explain traditional FDI with a focus on the idiosyncratic features of emerging firms and emerging countries. For instance, what became known as the first wave of emerging FDI was usually concentrated in neighbouring countries, because of the similarity of these markets to the home location (Narula, 2010). Another aspect noted by these studies is the prevalence of adaptation and absorption capacity as the predominant ownership advantages of emerging MNCs. These advantages were magnified by the presence of inward-looking, import-substituting, industrialisation regimes 
(Lall, 1983; Narula, 2010). The common feature shared by these early works is the emphasis on the differences between the competitive assets of emerging MNCs and those of traditional MNCs from the developed world.

The accumulation of technological capabilities influences the expansion and competitiveness of emerging multinationals. Innovation and technological specialisation are central features that shape competitive advantages. The involvement of firms in technological activities, influenced by certain location advantages, seems to have a growing importance for the accumulation of capabilities that are central to foreign expansion from this region (Cantwell and Tolentino, 1990). This central aspect is thoroughly discussed by all the studies of emerging FDI mentioned above.

According to Wells (1983), emerging countries (and hence their multinationals) have the opportunity to enter global markets in mature phases of the industry life cycle. The core competitive advantages of firms from emerging countries are associated with their ability to adapt old technologies to their local market endowments, thereby making use of the small scale and rich availability of labour and resources (Lall, 1983; Tolentino, 1993; Wells, 1983). Lall's approach to emerging multinationals goes beyond cheap labour and local adaptation by considering that developing countries have the capability to develop technological skills that are a direct product of their specific endowments. These countries have technological competencies (originating from the adaptation of advanced countries' technologies) which have the potential to become competitive assets in overseas expansion.

The investment development path (IDP), postulated by Dunning $(1981,1988)$ in the early 1980s and further developed in his later works, emerged as a response to the criticisms of his eclectic paradigm of firms' competitive advantages (the OLI model) (Dunning, 2001; Goldstein, 2007). Critics have argued that competitive advantages do not fully explain the internationalisation of firms from emerging economies, and that the OLI model gave a static picture of the subject (Goldstein, 2007). The IDP therefore develops the idea of a connection between the OLI competitive advantages of firms (and countries), which influence the FDI into and from a country, and the structural factors present in a country's economic background, which influence the level of economic development attained over time.

\subsubsection{Investment Development Path}

The core assumption of the IDP framework is that the economic structure and the level of development of a country are systematically related to the nature and magnitude of both inward and outward FDI (Narula, 1996). Higher income levels tend to be followed by the enhancement of capabilities and competitive advantages. This linkage between income and capabilities was present in the approaches of both Wells and Lall and, in this sense, the IDP framework is closely related to these two approaches (Tolentino, 1993).

It is important to stress that the relationship between FDI and economic development, as defended by the IDP framework, has technology (and innovation) as its central aspect. As posted by Narula (1996), technology has taken a central role in the 
debate of economic growth by some "heretic" theories, Neo-Schumpeterians and evolutionary theorists as their main representatives. It is therefore the changes in the innovative behaviour that determines the specialisation patterns of countries and, as a consequence, their economic growth. Technology, a feature expressed at the firm level, has a key role to the macroeconomic outcome of economic growth.

According to the IDP, countries undergo five main stages of development (the fifth was included in a later review; see Dunning and Narula, 1996), in which the propensity to receive and/or generate outward FDI evolves in accordance to their development level, measured by the gross national income (GNI) level. The propensity to carry out FDI is linked to the extent of ownership advantages of domestic firms relative to those of firms in other countries, and to the location-specific advantages of the country in question (as previously stated in Dunning's eclectic paradigm; see Dunning, 1981; Dunning and Narula, 1996). The entry of foreign firms into the domestic environment (inward FDI) plays a key role in enhancing the capabilities of firms and the country, because of the technological capabilities embedded in these firms that also come into the market. The presence of foreign firms, which disseminates knowledge via technological spillovers, triggers firm-level changes due to increased competition, therefore enhancing local capability accumulation. Such accumulation is central to increasing competitiveness in (foreign) markets. 
Figure 1.1: Investment Development Path



Source: Reproduced from Dunning and Narula (Eds.), Foreign Direct Investment and Governments: Catalysts for Economic Change. London, Routledge, 1996.

Legend: NOI $=$ Net Outward Investment; $\mathrm{GOI}=\mathrm{Gross}$ Outward Investment; $\mathrm{NII}=$;Net Inward Investment, IDP=Investment Development Path; GNP=Gross National Product.

According to Dunning (1981) and Narula (1996), the shape of the curve showing different countries at increasing levels of development should resemble a $J$ (Fig. 1): after a deep fall, an upward slope in net outward FDI is expected, as stronger levels of economic development are achieved. At the microeconomic level, firms are expected to move from less knowledge-intensive sectors towards higher-technology sectors as a result of the evolution of their OLI advantages - again, a result of technological accumulation enhanced or stimulated by the presence of foreign capital. At the early stages (Stages 1 and 2) of development, advantages are limited, and both inward and outward direct investment levels are low. The movement towards later stages of development - seen in higher levels of GNI-represents the upgrade in the competitive advantages of the country, which thus becomes more attractive for foreign investments. As the country's competitive advantages increase, as a result of enhanced capabilities at the firm level, the curve has an upward slope (Stage 3). Enhanced capabilities are increased technological capabilities at the firm level. The country, through increasing levels of outward and inward FDI, then advances in the IDP curve, reaching a positive net outward investment position at the later stages (Stages 4 and 5). 
The fifth stage is a result of the increasing convergence among developed economies associated with increased globalisation of markets (Dunning and Narula, 1996; Narula, 1996). It occurs when firms have accumulated a level of capabilities such that their home country's comparative advantages are less relevant to the location choices of foreign investments. Furthermore, outward and inward investments tend to fluctuate near the nil level, as they become more balanced and, at the same time, income levels tend to equalise. Developed countries with similar economic structures and competitive assets are believed to be located at this stage of the IDP graph. According to Ozawa (1992), this also represents a narrowing of the technological gap among these countries.

Since the 1990s, the IDP approach has been analysed in the context of several economies, mainly developed nations but also developing countries such as India, China, Mexico (Narula, 1996), and the Philippines (Tolentino, 1993). Developing or emerging economies are generally located at the first three stages of the IDP (Dunning et. al., 1997; Tolentino, 1993). As discussed above, at these stages, location and home-country advantages are important determinants of outward investments (Dunning and Narula, 1996).

Tolentino (1993) carried out a pioneering study analysing the IDP for leastdeveloped countries. Using FDI flows, the author did a cross-session analysis of the investment patterns of thirty countries over a long time span: 1960 to 1984 . Her results indicate two determinants of the shape of the IDP curve: a change in the motivations for investing abroad and the growing role of governments in stimulating FDI. A study carried out by Narula (1996) applied FDI stocks to the analysis of the position of forty countries along the IDP curve. This exercise confirmed the J-shape of the curve, but showed a somewhat different positioning of countries compared to the early suggestion. This is a consequence of the process of economic convergence, taking place mostly in advanced economies.

Later, the IDP was tested for a series of countries, especially large, industrialised countries. The FDI of smaller industrialised countries, such as Portugal and Austria, has also been analysed from the IDP perspective (Bellak, 2000; Castro, 2004). Empirical tests have suggested that the shape of the curve tends to vary between countries, as a result of their specific economic structures, development strategies, and macroeconomic policies (Dunning and Narula, 1996). Some studies have suggested add-ons to the original IDP framework, based on the assumption that a more elaborate (multivariate) econometric model could better capture the relationship among variables, and that GNI alone cannot accurately indicate a country's level of economic development (Duran and Ubeda, 2001). In other words, a complete understanding of a country's situation in terms of FDI must consider factors such as home-country location advantages and the absorptive capacity (Narula, 2010).

To summarise, studies on the IDP so far have suggested that the FDI positioning of countries is influenced by a range of individual characteristics, and that public policies can influence the expected shape of the curve. Furthermore, as firms (and their home countries) accumulate and develop new capabilities, the positioning in terms of net investments becomes firm-level rather than country-level. This makes each case 
individual, therefore requiring deeper study of all the aspects superficially approached by the IDP.

\subsubsection{Brazilian Investment Development Path}

Brazil is still understudied, in terms of its outward foreign investments. There are few studies exploring the micro-macro relationship as put forward by the IDP approach ${ }^{2}$. To our knowledge, there are no studies analysing the impact of industrialisation and macroeconomic structure on the patterns of Brazilian outward investments. This omission motivates our study. An analysis of the macroeconomic background will also be helpful in understanding how Brazil developed a specific FDI pattern that has changed only slowly in the last thirty years.

This section presents the Brazilian IDP and assesses the evolution of the country in terms of its investment position for the period 1980-2005. Data were obtained from the World Bank Development Indicators (GNI) and from the UNCTAD FDI statistical database (inward and outward FDI stocks). Values are in current USD. Population data were obtained from the Brazilian Statistics Office, IBGE.

Brazil is an interesting example of emerging-country FDI. Until the 1990s, it was the leading developing country in terms of outward stocks (UNCTAD, 2006). In the late 1990s it was outpaced by East Asian economies, dropping to fifth position in 2000 and reaching seventh place in 2005 (see Table 1).

While still the leading investor country in Latin America, the rate of growth of Brazilian FDI is far behind that of its neighbours. While outward Brazilian FDI stocks were twice as high in 2005 as in 1990, in other Latin American countries (e.g. Argentina) the stock of FDI in the same period at least quadrupled, with the highest rates observed in Mexico and Chile: 13- and 23-fold respectively (UNCTAD, 2006). In general terms, apart from a few isolated cases, the internationalisation of Brazilian firms via FDI remains limited.

The slow internationalisation pace of Brazil is even more evident when comparing the Brazilian IDP to that of East Asian economies. For instance, China increased outward investment from USD 4.5 to 95.8 billion from 1990 to 2007 (UNCTAD, 2008). In terms of GDP shares, Brazilian outward investments have gone from $16 \%$ in 1980 to $9 \%$ in 2010 , while China has gone from $0.02 \%$ to $5 \%$ of a rocketing growing GDP in 2010.

Figure 2 presents the inward and outward FDI trends of Brazil from 1980 to 2005. It shows that outward FDI stocks were much higher than inward stocks for 1980 to 1992. Inward FDI played a central role in the industrialisation period, then declined in the 1980s because of the Brazilian debt crisis and the general economic slowdown. It did not recover until the mid-1990s, when regulatory measures were revised and investment to attract more investments, even in previously protected sectors (Cassiolato et al., 2001).

\footnotetext{
${ }^{2}$ To our knowledge, there is only one previous study using the IDP for Brazil. Goldstein and Pusterla (2008) apply the IPD to comparatively assess emerging FDI from Brazil and China.
} 
In the 1990s, trade levels and trade balance have remained unchanged, regardless of the policy shift that took place. It was only in 2000 that trade levels have doubled in comparison to 1990, reaching US\$ 107 billions (Ferraz et al., 2004). Such numbers might reveal a strong preference, by Brazilian investors, to access foreign markets via exports.

The relatively high levels of outward FDI during the 1980s might be related to statistical calculations. The statistics for Brazilian outward investment did not distinguish direct investment from loans, supplier's credits, and reinvestments; this inflated the numbers (Lall, 1983). For instance, civil construction investments, which formed a large part of Brazilian outward FDI in the 1980s, added to their equity the value of overseas constructions, further overestimating investments in this sector. In spite of these possible inaccuracies, the data (the only available) provide a reasonable picture of the general trends in Brazilian inward and outward FDI during an important period of economic restructuring. At this time the country went through a series of neoliberal reforms that reflected a higher openness to trade and investment (Chudnovsky et al., 1999; Goldstein, 2007). The numbers also highlight the recent increasing trend in outward investment, which reached, for the first time in the mid-1990s, levels above USD 50 billion (UNCTAD, 2007).

Figure 1.2: Brazil inward and outward FDI stocks, 1980-2006

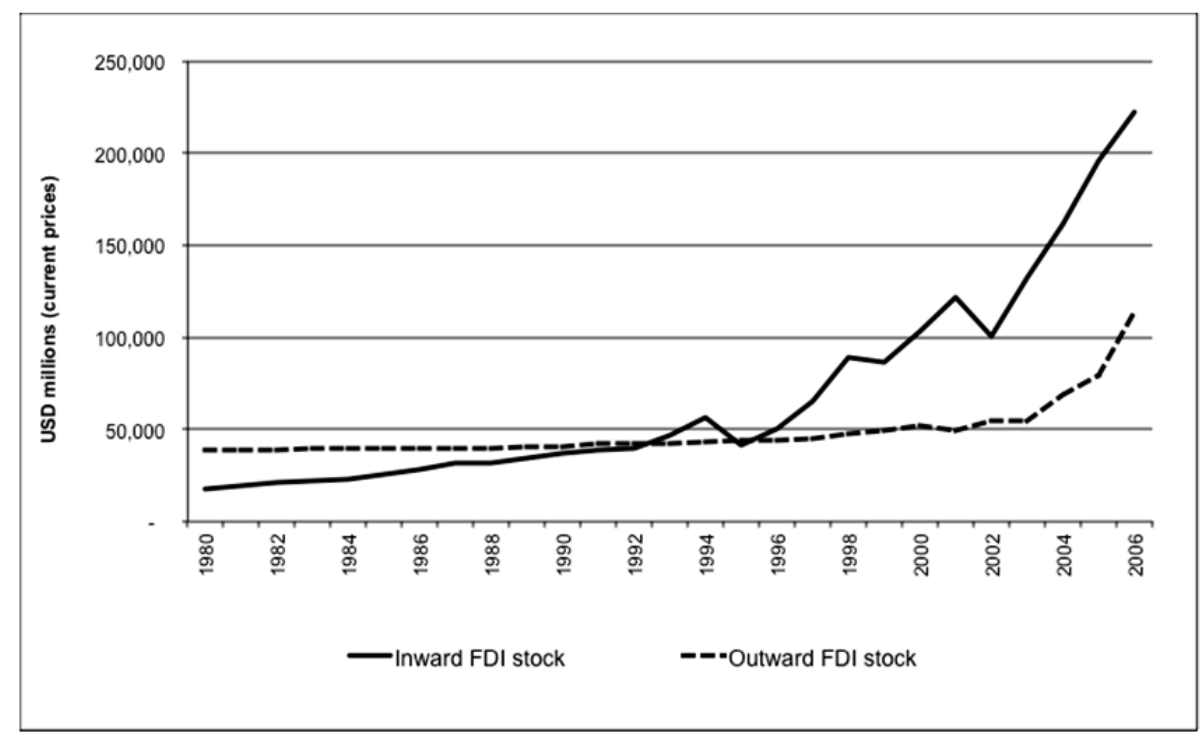

Source: UNCTAD statistical database (2007).

The empirical analysis applied here for Brazil follows the guidelines of similar exercises and uses a quadratic function for the variables net outward investment (NOI) and GNI, both in per capita terms (Dunning, 1981; Tolentino, 1993; Narula, 1996). 
The values of both inward and outward FDI refer to investment stocks. A summary of the estimation results is presented in the Appendix at the end of this chapter. The following equation describes the curve:

$$
\text { NOI pc }=\alpha+\beta_{1} \text { GNIpcap }+\beta_{2} \text { GNIpcap }^{2}+\mu
$$

Figure 3 presents a scatter diagram for the period 1980-2005. The points that refer to recent years suggest that Brazil is at Stage 3 of the IDP. The curve has started changing its orientation and outward investment has started growing, but it does not yet outpace inward $\mathrm{FDI}^{3}$.

Figure 1.3: Brazilian IDP, 1980-2005

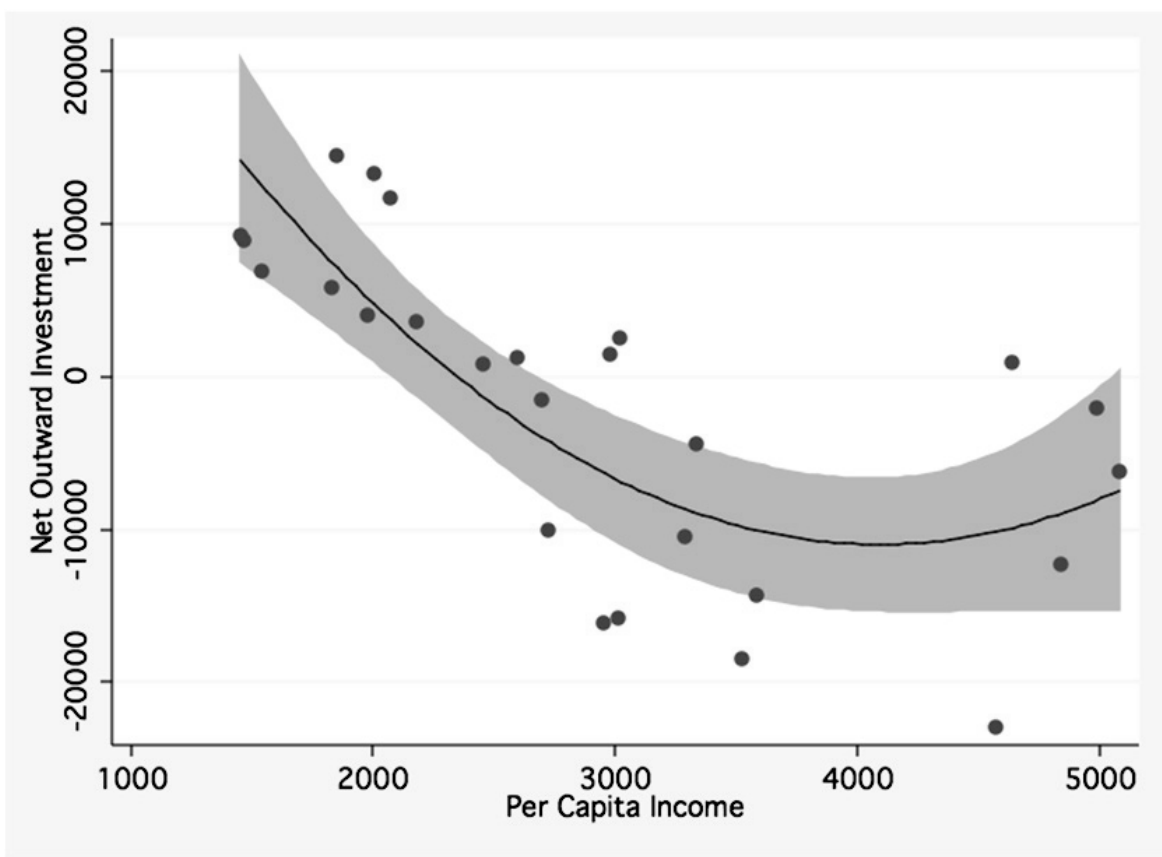

Source: Based on author's calculations using Stata 10.0

Earlier analyses of Brazilian investment position (in combination with that of several other developing economies) obtained similar results (Tolentino, 1993; Dunning, 1981), also placing Brazil at Stage 3 (in the early 1990s). An analysis of the IDP is a good starting point for understanding the positioning of Brazilian investments. Indeed, it seems that structural changes influence economic development, and also affect the levels of both inward and outward FDI (Goldstein and Pusterla, 2008). Next, we ex-

\footnotetext{
${ }^{3}$ For the very first time in 2006, FDI outflows outpaced inflows, a result of the giant merger operation of Brazilian Ambev with Belgian Interbrew and the acquisition of the Canadian steel company Inco by Vale.
} 
plain in greater depth how structural changes and the economic trajectory led Brazil to the position observed in the IDP curve.

\subsection{Understanding the Brazilian Economy: Development Strategy and Economic Structure}

In this section we take a closer look at some aspects of the development context and the macroeconomic structure of the Brazilian economy to understand the aggregated performance of foreign investments by Brazilian firms.

There are two main aspects that we consider determinants of the country's position as an outward recipient and investor. The first is the industrialisation strategy, which has a clear influence on a country's economic structure. For Brazil, we analyse how the division of tasks among the state, foreign multinationals, and private domestic firms - established during the ISI followed in the import-substitution period-has shaped competitive strengths. Another relevant issue is the natural-resource endowment as a location advantage for Brazilian firms, and its influence on the industrialisation trajectory (Tolentino, 2000). The second main aspect is the changes in the Brazilian macroeconomic context. We highlight the impact of the 1980s economic slowdown and the 1990s process of liberalisation on the nature, pattern, and volume of foreign investments by Brazilian firms.

\subsubsection{Import-Substitution Industrialisation: Local Market, Foreign Multinationals,} the State, and Natural Resources

Several aspects of the import-substitution industrialisation (ISI) process, carried out in Brazil from the early 1950s, influenced the internationalisation patterns of Brazilian firms, hence impacting the nation's investment development path. We discuss four aspects: the predominantly inward orientation of Brazilian industrialisation and its impact on business strategies; the massive participation of foreign multinationals and their influence on local companies; the role played by the state, particularly in the productive sphere; and Brazil's abundant natural-resource endowment, and its effects on the productive structure of the country.

The industrialisation path chosen for Brazil was, as in most Latin American countries, the inward-looking ISI. The purpose of the import-substitution process was to develop and protect the nascent domestic industry and to lessen the country's dependence on imported goods (Baer, 1995). Brazil was the country that succeeded the most in terms of building a diversified industrial complex through ISI (Lopez, 1999). In the late 1950s, the country already had a diversified and complex industrial basis, comprised of heavy industry and durable goods as well as non-durable and basic consumer goods. However, the consequence of the focus on the local market was fewer internationalised businesses. In contrast, more outward, export-oriented industrialisation strategies were followed by the new industrialised economies from East Asia (Narula, 1996). 
The emphasis on the development of the domestic market led naturally to a small presence of domestic firms in global markets (although the country remained dependent on imported inputs; see Baer, 1995). This trend began to be reversed with the liberalisation of the domestic market with respect to imports and FDI in the early 1990s (Baer, 1995). Along with a small international presence, for several decades Brazilian firms were protected from competition with foreign firms in certain sectors. This is why many firms did not become competitive and innovative. On the other hand, the economic openness of the 1990s came abruptly and unexpectedly, without a reinforcing industrial policy to foster the technological development of local firms. They were left without the tools to respond to the sudden change in market dynamics.

A second noteworthy, and maybe more important, aspect of Brazilian import substitution is the strong participation of foreign multinationals in the country's industrial base. From the mid-1950s to the late 1980s, foreign subsidiaries were a central instrument in the ISI process, being an important source of capital and technology for the increase of production capacity (Moreira, 1999). Thus, foreign multinationals have a solid and long-lasting presence in the Brazilian economy. They are amongst the largest firms in the country in terms of value added, employment, new technologies, exports, and other economic indicators (Costa, 2005). Foreign multinationals have dominated most capital and durable-goods industries, accounting for the largest part of technologically intensive sectors in Brazil (Sarti and Laplane, 2002). In the early 1980s, multinationals accounted for less than 30 percent of industrial production, reaching 50 percent in the 1990s. Moreover, in the 1980s foreign firms accounted for 38 percent of all manufacturing exports from Brazil (Lopez, 1999).

The strong role of foreign firms in the country's productive structure had a significant impact on its investment position in the IDP graph. This influence, a result of the high levels of FDI inflow that Brazil has received since the 1960s, and particularly in the 2000s, has two channels. Both are at the microeconomic level. First, foreign companies established in the country provide a competitive pressure on local companies, which need to defend their market shares domestically, regionally, and eventually abroad. Recently, reacting to such competitive pressure via overseas expansion has been considered a matter of survival (Iglesias and Veiga, 2002; Arbix et al., 2004; Goldstein, 2007). However, firms have limited time to prepare for and react to such competition.

The second channel of influence concerns the role of foreign multinationals as a benchmark for local companies. The latter can improve their resources and ability to survive and expand, both within and beyond the domestic market (Franco, 1998; Dunning, 2001). Foreign firms disseminate modern technologies to the local market, via spillovers. On the other hand, a reliance on foreign technologies — without the support of strong innovation policies for domestic firms - limits the development of an innovative and dynamic indigenous industry. This division of tasks between domestic and foreign firms explains why most internationalised Brazilian firms do not come from knowledge-intensive sectors; instead their competitive advantages are based on the exploitation of natural resources. 
Lall stated in an early work on emerging foreign investment that the small presence of Brazilian multinationals in manufacturing was a consequence of the vast presence of foreign multinationals in the industrial structure of the country and the resulting heavy reliance on foreign technologies, especially in comparison to other emerging countries, such as India (Lall, 1983). In the 1980s, India had a much higher share of manufacturing investments abroad ( 0.6 percent against Brazil's 0.05 percent). The influence of the industrialisation process on this characteristic of Brazilian investments is clear.

As in several other Latin American countries, the state took on tasks related to orchestrating the industrialisation process as a whole, in terms of providing appropriate infrastructure and also by participating in the productive sphere, particularly in segments related to the supply of raw materials and basic industries. State-owned firms have traditionally controlled the main natural-resource industries. Vale and CSN, among others, controlled mining, Petrobrás controlled oil, and several state firms controlled facility provision. Recently, in the restructuring of the economy that we will describe later, these firms have been privatised; many of them have been taken over by foreign capital. However, the productive role of the state was not restricted to the natural-resource-based sectors. Consider for instance Embraer, a successful Brazilian multinational and the third largest producer of aircraft worldwide, after Boeing and Airbus (Goldstein, 2008). The company was originally state-owned, with strong ties to the Brazilian army. Private domestic firms, in their turn, historically dominated technologically mature industrial sectors. These industries benefited from local protection for a long period before the economic openness (Lopez, 1999).

The pattern of Brazilian outward investment, since its beginning in the 1980s, suggests a still weak and incipient international presence. It started primarily as an effort to boost the country's export performance, and continued over the years with a strong concentration in resource-based sectors. The relatively small presence of manufacturing firms remains a major characteristic of Brazilian outward FDI. This is an indication that Brazilian firms have a reduced presence in capital- and technologyintensive sectors, and that their competitive position in those sectors is still low.

Another aspect of Brazilian industrial development that had implications for Brazil's IDP is its natural-resource endowments. Much can be said about a country's sectoral patterns of foreign investment by looking at its natural-resource endowments. This has its roots in the theory of comparative advantages (Cantwell and Tolentino, 1990; Tolentino, 2000). Brazil has always relied on an abundance of natural resources and its industrial base is a reflection of that. In the course of economic development, firms from resource-rich sectors accumulated technological capabilities that enabled them to achieve better performance and subsequent expansion. Exploiting an abundance of natural resources on a worldwide basis takes time, and it is not surprising that firms from resource-rich countries have seen their stronger multinationals achieve dominant positions in resource-rich sectors. It is not by coincidence that two of the top Brazilian multinationals are Petrobrás and Vale, which are followed by other large companies such as Gerdau, Camargo Corrêa, and Odebrecht (FDC and CPII, 2007). 
To summarise, the industrialisation process that took place in Brazil gave a specific shape to the domestic industry. The abundance of natural resources, the division of tasks between domestic and foreign firms, and the strong state intervention in strategic sectors produced a specific set of advantages and therefore a particular range of foreign-investing firms. The technological competences of Brazilian firms have been moulded by political choices, especially regarding industrialisation, but they also reflect more recent initiatives in terms of industrial and innovation policies. The technological capabilities developed by Brazilian firms are, to a large extent, related to the pattern of industrialisation followed, the level of reliance on foreign capital, and the orientation of domestic industrial policies. Future policies may have the power to revert or at least reduce the low internationalisation rate of firms from Brazil.

1.3.2. Macroeconomic Context: The Economic Slowdown in the 1980s and the Liberalisation in the $1990 \mathrm{~s}$

The macroeconomic context is important in explaining how a country evolves along the IDP curve. For Brazil, this context has undergone great changes in recent decades. The industrial sector had to adapt to the new reality. We highlight two events that had a major impact on the dynamics of Brazilian firms: the period of economic stagnation in the 1980s and the economic liberalisation in the 1990s.

The 1980s are known as the 'lost decade' for the Brazilian economy. They were in part the result of a huge indebtedness accumulated in the years of economic prosperity (1967-73), when the country grew at an annual average of 11 percent with strong support from foreign capital. The consequent inflation made the price of capital too high to sustain investment and growth, and the country experienced a severe slowdown, with public debt reaching record levels. As a result, industrial production stagnated, and the trade balance and the balance of payments reversed their positive trends from the pre-growth period to reach USD 11 billion in 1981. The rise in domestic as well as international interest rates to unprecedented levels played a major role in the rise of indebtedness levels (Bresser Pereira, 1984).

The economic slowdown and consequent retraction of domestic demand are among the main drivers mentioned by Brazilian entrepreneurs for their initial overseas ventures. These formed the first wave of Brazilian outward FDI in the mid-1970s (Villela, 1983). According to the Central Bank of Brazil, foreign investments by domestic firms were concentrated in financial services, accounting for 52 and 54 percent of FDI flows in the years 1979 and 1980, respectively (Villela, 1983). The strong presence of banking investments overseas was credited to the banks' strategy to support export activities by Brazilian firms. Foreign investments from Brazil in the eighties were a result of the economic scenario.

The 1980s were an economically closed period. Foreign multinationals had been operating in the market since their entrance during the period of import substitution, but without the competitive pressure of imports. Many economists consider this to be the reason that Brazilian firms, including local subsidiaries of foreign multinationals, 
became obsolete and/or little innovative. They were secure in their protected markets (Franco, 1998).

The years of economic slowdown were also the period of the international oil crisis. During this time, foreign capital reduced investment in Brazil (as elsewhere) to an average USD 1.5 billion (ranging from a peak of 2.9 billion in 1982 to 345 million in 1986 according to the world development indicators; see World Bank, 2007). On the other hand, there was no reversal of the already stable trend of outward investment (Fig. 4). Outward flows originating from Brazil remained at around USD 300 million in 1980 and would not double these levels until the 1990s. It is reasonable to interpret the economic slowdown as a double-edged sword for outward investment from Brazil. It acted as a push factor leading companies to search for alternative markets, but at the same time constrained the possibilities of expansion for many firms as a result of financial difficulties both locally and internationally.

Figure 1.4: Brazil FDI inward and outward flows, 1975-2011

(USD million, current prices)

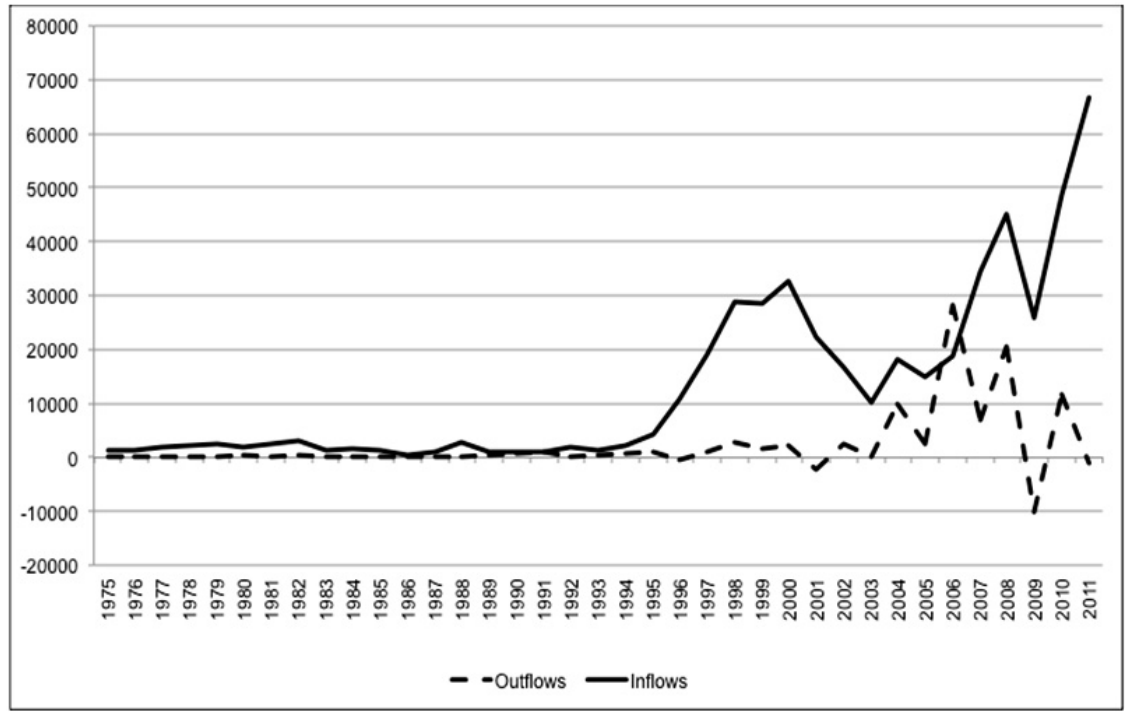

Source: UNCTAD Statistical Database. Available at: www.unctad.org. Note: The line for the outflow series is very low in the first 25 years due to values in the order of hundreds of millions until a first huge rise in 2004, when it reached 9.806 USD millions. Outflows were negative in the years 1996, 2001 and 2009.

After years of stagnation and inflation, in the mid-1990s Brazil recovered economic stability. In 1994, an ambitious economic plan returned monetary stability and purchasing power to consumers. The period coincided with the adoption of more liberal policies towards investment and trade, following the Washington Consensus agenda. 
One of the central measures was the privatisation of public enterprises to restrain the influence of the government in the private sphere. In response to this policy change, there was a boom in inward foreign investment, which aimed to acquire some formerly public businesses and was also attracted by the increasing domestic demand. A peak in investment flows occurred in 1998, when USD 31.9 billion were injected into the Brazilian economy (World Bank, 2007; see Figure 4).

A group of economists, many in the government at the time, believed that an expansion of foreign multinationals in the economy would ease the external restrictions imposed on economic growth by the balance-of-payments constraint (Franco, 1998). Multinationals would spur competitiveness and efficiency, and therefore automatically lead to the catching up of the more obsolete, less efficient firms. Another group of economists believed that this would have a serious negative impact on the competitiveness of domestic firms, caught off guard by the abrupt entry of many new competitors into a previously secure market.

Meanwhile, outflows of FDI from Brazilian firms remained stable at around the levels of the previous decade. Foreign competition did have some positive effects on the competitiveness of domestic firms, but many such firms did not have the strength to survive the sudden and unexpected openness of the Brazilian market. This resulted in a series of acquisitions of previously successful domestic firms by foreign interests.

The case of a domestic auto-parts company, Metal Leve, illustrates the impact of economic and trade liberalisation on domestic firms in Brazil. Metal Leve had been in operation since the 1950s and was a leader in the Brazilian market in the production of pistons, with an internationalisation strategy that started in the 1980s. It did not survive the imbalances caused by the fall in international prices and the growing pressure from its main competitor, Mahle. It could not find the financial vigour required to expand on the scale necessary for survival (Rocha and Arkader, 2002). According to Metal Leve's founder, Jose Mindlin, "the openness of the Brazilian market was done so abruptly that firms were forced to react with no time to prepare for it" (Rocha and Arcader, p. 162; my translation). Metal Leve was purchased in June 1996 by a joint venture of Mahle, Cofap, and Banco Bradesco.

To summarise, the economic stabilisation of the 1990s had both positive and negative impacts on the international expansion of Brazilian firms. Economic growth and demand recovered from the stagnation of the previous decade, but competition reached unprecedented levels. Local firms that had long operated in an overprotected domestic market were caught off-guard (Lopez, 1999). Adaptation to the new market reality took several years. However, the time and effort needed to adapt and react to the market changes were not equally available to all domestic firms, because no industrial or innovation policy was implemented concomitantly. As a result, there were no major changes in the internationalisation pattern of Brazilian firms during the decade. The internationalised firms of the 1990s were, mostly, those who had started this process in earlier years.

We can conclude that the main impact of the economic openness implemented in Brazil in the mid-1990s on the country's economic structure was the increasing internationalisation of its industrial base and a higher reliance on foreign technology (Cas- 
siolato et al., 2001; Sarti and Laplane, 2002). Domestic firms have since made efforts to change their dynamics, increasing their innovation and competitiveness. The process of adapting to a new competitive environment is long and complex, and almost impossible without the support of substantial industrial policies.

\subsection{Emerging Multinationals and the Role of Policies}

The recent intensification of the internationalisation of firms from emerging markets has stressed the changing role of governments in determining the investment position of countries, both through FDI-attraction policies and outward-FDI fostering initiatives. This section discusses Korea, China, and Brazil. Korea and China have experienced a remarkable growth in outward FDI since the 1980s. Also, Korean multinationals have achieved worldwide recognition, and China is the apple of analysts' eyes. They are therefore used for a comparison with the Brazilian approach to internationalisation in the last thirty years.

\subsubsection{Outward FDI Policies in Korea}

To understand the Korean approach to outward FDI, it is necessary to understand its industrialisation and development trajectory. Korea's remarkable growth and development over the last three decades is an example of a successful government-driven international expansion, and its outward investments are regarded as an important component of the development the country has achieved.

The market structure developed in Korea for its industrialisation had large conglomerates, known as chaebols, as a key unit. The development of a concentrated structure was the central instrument of industrial policy. The intention was to create strong competitors to face foreign competition in key sectors. This structure has given Korean firms the strength to achieve leading positions in world markets.

This is the case, for instance, for the country's car industry, non-existent until the 1970s. The companies sought foreign markets to achieve competitiveness, which could not be obtained in the limited domestic market. FDI was a central part of the catching-up strategy, and location choices were decisive. The industry's international drive is described as 'capability-push' (Sachwald, 2001). The governmental support was strong; it included preferential credit allocations, export incentives, and regulatory measures. This allowed the industry a remarkably fast growth. Technological transfers from advanced producers (Italian design, core components from Japan, and English engineering), a strong export policy, and the in-house production of components played an essential role (Sachwald, 2001).

A similar approach of government support and technological transfers was applied in the Korean electronics industry, which produced major global players such as LG and Samsung. The sector quickly shifted from an export orientation to internationalisation. The sector accounted for 25 percent of Korea's outward FDI in 1997, mainly through production facilities (Sachwald, 2001, Chapter 5). 
Korea did not have a positive approach to outward FDI until the late 1980s, when an improvement in the country's economic stability enabled the liberalisation of outward investments, which are controlled by the government but not restricted. Korean outward investments soon outpaced the inward FDI levels, and are now close in IDP position to those of developed economies (Sachwald, 2001).

The active role of the Korean government in the development achieved in the last thirty years is widely acknowledged. The export-oriented industrialisation policies were the starting point. Combined with a welcoming, but cautious, FDI orientation, they led the country to an impressive export performance in a short time span. Sectoral orientation was also part of the agenda. In the 1970s, the priority sectors were heavy and chemical industries. These sectors benefitted from a series of policies, and special government credit concessions played a major role (Sachwald, 2001).

Outward FDI policies have become a current focus of government policies, in recognition of the importance of integrating the Korean economy globally. A key objective of these policies is to enhance the country's technological capabilities, although there has never been a formal technology policy (Sachwald, 2001: 33). The specific policies to enhance FDI in Korea are loans at lower rates, tax incentives and exemptions, bilateral treaties to avoid double taxation, and information and technical assistance from foreign offices coordinated by different government departments.

Samsung is a good illustration of the country's success in shaping industrialisation policies that would later lead to successful internationalisation and strong global players. Chang (2007) tells the Samsung story as an illustration of the role of policies in the industrial and technological development of emerging countries. Samsung started in the late 1930s as an exporter of fish and agricultural products, and until the early 1970s the company's main line of business was sugar refining and textiles. After acquiring 50 percent of a semiconductor industry, Samsung declared this industry to be its new main line of business. This was discredited by most observers, but the company, supported by a strong governmental commitment to develop and lead the semiconductor industry globally, started to design their own chips. The industry development and the global leadership were both attained.

The case of Korean development and its success to bring to life major global players such as Samsung have been widely studied and disseminated in the economics and international business literature. Our purpose here was to illustrate how policies can shape the patterns of industrial development even in cases that could at first have seemed doomed to a mediocre path.

\subsubsection{Chinese Go Global Strategy}

As a communist country, China has strong state control of its economy. Until the 1980s China had a strict policy towards inward investment, which had to be approved and to take place only as joint partnerships with local firms. The 'open door' policy that began in 1979 started the process of enhancing the country's communication and exchange with the rest of the world. Several restrictions remain; for instance, no outward investment can be done without the approval of the Chinese Ministry of Foreign 
Trade (MOFCOM) and the National Development and Reform Commission (NRDC). This is a method used by the government to keep Chinese investments in line with national policies (Gugler and Boie, 2009). The Chinese government plays a strong role in the directions and strategies of China's outward FDI.

The Chinese Go Global strategy took off in the early 2000s as an overall strategy to increase the country's presence in the global economy. Overseas investments by Chinese firms, with the goal of improving resource allocation and enhancing international competitiveness, became a central point of the strategy (UNCTAD, 2006). A series of policies was designed to regulate and support outward investment, such as supportive credit, cooperation agreements with over 140 countries, and tax relaxation for at least five years for foreign-investing domestic firms.

Outward investments by China started with the expansion of state-owned enterprises (SOEs). Today, SOEs still account for the largest share of Chinese outward investment. The government follows a clear strategy of creating and fostering national champions in key industries, and nurturing their outward activities. Their outward orientation is particularly important to the country's development strategy when the companies in question are not natural champions, but firms internationalising to address competitive disadvantages. The national global champions are of two kinds: firms that seek to sustain the Chinese miracle by gaining access to natural resources not available in the country, and firms venturing into advanced industries and services, such as IT, electronics, and electrical industries (Mirza and Giroud, 2005). The selected champions, either SOEs or private firms, have a close relationship with the government, in terms of following its guidelines and benefitting from its subsidies.

The role of the government in the building of global champions is strong. Because there are so many regulations and approval requirements, and an explicit encouragement for investments in certain sectors, it is reasonable to affirm that policies have shaped the strength and orientation of Chinese multinationals (Buckley et al., 2007; Gugler and Boie, 2009). Because Chinese firms rely heavily on countryspecific advantages, the political directions of the domestic economy, together with a strong support policy, have been fundamental to the competitiveness of Chinese multinationals (Rugman and Doh, 2008).

China has some remarkable cases. One of the most discussed moves of Chinese enterprises in the global market was the acquisition of IBM PC division by Lenovo in 2005 , with strong government stimuli (and capital) in the process. The jump into the computer industry with a strong, internationally known brand became a distinctive feature of the internationalisation that Chinese firms hope to achieve.

\subsubsection{Policies Fostering the Internationalisation of Brazilian Firms}

In Brazil, the debate on the internationalisation of domestic firms emerged as part of a broader discussion on how to enhance export performance. In fact, until the 1990s, the international presence of Brazilian firms referred mostly to their export penetration (Moreira, 1999; Sarti and Laplane, 2002). 
At that time, the Brazilian economy was closed to imports and the local market remained protected in several key industries (such as informatics). In the early 1990s, there was a change in the economic paradigm from 'inward-looking, import substitution' towards the adoption of a Washington-consensus-oriented economic openness and state withdrawal from the economic sphere. This altered the way entrepreneurs envisaged competition and market consolidation.

After the economic openness to imports and to a larger range of foreign investments, we notice an increased interest from domestic firms in investing in foreign markets. They were led to internationalisation for various reasons that varied among sectors and firms. The scenario shifted to a more competitive domestic environment and demand for excellence in product quality and process efficiency.

In the last few years, the debate on the internationalisation of firms from emerging countries has gained energy because of a significant rise in the investments originating from these regions. More and more studies of Brazilian firms have become available, leading to a heated debate of the purpose and consequences of internationalisation. On the one hand, entrepreneurs strive to enlarge the global reach of their firms, while also try to maintain their domestic prominence. On the other hand, the government is quietly trying to position itself in relation to this. Until recently, foreign investments by Brazilian firms were seen negatively in the governmental realm: they represented a draining of capital and jobs and competition to domestic investments. At one point the government referred to the foreign acquisitions made by firms like Vale as the 'denationalisation' of those companies ${ }^{4}$.

From its early wave in the 1980s until recently, most foreign investments by Brazilian firms were the result of the firms' own initiatives, with little or no participation by the public sector to stimulate the process. The exception, of course, was those state-owned firms with a strong international presence, such as Petrobrás. The year 2002 marks the start of policy initiatives, with the development of deliberate policies to redefine the international presence of Brazilian firms.

Since then, a series of initiatives and policies have been proposed to stimulate and facilitate the internationalisation of Brazilian firms. The release of the industrial, technological, and foreign trade policy (PITCE) in 2003 can be considered a turning point in policies dealing with the international expansion of Brazilian firms. PITCE aimed to promote Brazilian firms in foreign markets, to stimulate the creation of overseas distribution centres, and to strengthen Brazilian brands.

The PITCE policy had as a strong priority the enhancement of the so-called 'promising sectors of the future', such as biomass, nano and biotechnologies. It also emphasised priority sectors in which Brazil does not yet hold a competitive position: semiconductors, software, capital goods, and pharmaceuticals (Almeida, 2009). In other words, this policy tries to stimulate the sectors that do not have an important effect on the trade balance as well as sectors that have a negative effect on the trade

\footnotetext{
${ }^{4}$ This was a reference to the possibility of Vale using foreign funding to acquire Xstrata. The acquisition did not take place.
} 
balance. High-tech and medium-high technology sectors historically have a negative trade balance. Brazil performs better in non-industrial and low-tech sectors.

Following PITCE, the government released the productive development policy (PDP), with a clearer purpose to foster the productive internationalisation of Brazilian firms. In the PDP, some sectors were selected as priorities, with the goal of consolidating and expanding international leadership in sectors where Brazil already performs well: biofuels, aerospace, quarrying, oil/gas/petrochemicals, mining, pulp and paper, and meat/poultry (MDIC, 2009).

The international expansion of Brazilian firms is also being stimulated in the South-South context. African countries have long been important markets for Brazilian products, services, and production. Petrobrás, Vale, and Odebrecht, some of the largest Brazilian multinationals, have considerable investments in the African continent, and their industries are targeted by recent policies (PDP) as important goals for development.

The main recent tool to foster internationalisation is the concession of investments by BNDES, the country's development bank. Since 2003 there has been a special credit line for the support of international operations of Brazilian firms. Few firms have used the credit line since 2007, and 2008 was perhaps the year with the most credit access. In 2008, most credit grants were to firms in average and low-tech sectors. These were mostly meat producers that expanded abroad via major acquisitions of firms in developed countries (Almeida, 2009).

A strong debate is under way in the Brazilian media about the role of BNDES as a provider of funding to selected sectors, not by coincidence those that have the largest Brazilian multinational groups. The policy is one of the central pillars of the PDP, established in 2008 to foster the innovation and internationalisation of Brazilian businesses. Besides focusing on strategic sectors such as biotech and health, and fostering competitiveness in sectors such as automotive and capital goods, the policy seeks to consolidate leadership in sectors where Brazilian firms already perform well.

Some analysts view BNDES negatively, because it has prompted a strong concentration on certain sectors. Others agree that it might be the only chance for Brazilian firms to finally gain a worldwide scope. This disagreement is the main reason that internationalisation has not taken off as a strategic governmental effort to build a truly global economy with growing international impact.

\subsection{Concluding Remarks}

In this chapter we highlighted the linkages between Brazilian foreign investments and the country's economic structure. These are the result of policy choices for industrialisation and also of important changes in the economic structure in the last thirty years. Following the IDP framework, we conclude that Brazil is moving steadily though slowly along the investment curve, because there have been both positive and negative factors impacting firms' willingness and ability to expand and compete. 
The pattern of low but steady outward FDI can be partially explained by a turbulent decade of stagnation, inflation, and indebtedness, followed by years of economic openness and the massive entry of foreign capital. It seems that protected markets, which have benefitted domestic firms for decades, did not stimulate the necessary dynamism for competition with both new foreign investment and imports.

The inward-looking ISI had a great impact on the ownership advantages that Brazilian firms developed over time and therefore influenced their patterns of international expansion. The long-lasting market protection that was part of the industrialisation policy in Brazil also limited their competitiveness compared to their international competitors.

Inbound FDI flows from foreign firms to Brazil also played an important role in the continuing persistence of a negative net outward investment (NOI) position. With the economic stabilisation and the privatisation process, foreign investment flows regained strength, stimulated by the growth of a domestic market that remained stable for almost a decade and by the rise of a South American common market, the Mercosul (Lopez, 1999). At the same time, the lack of national policies stimulating the development of technological capabilities in domestic firms led to the poor performance of Brazilian outward FDI.

Two other aspects are worth attention. First, much emphasis is placed on the increasing role of government policies for outward investment in reshaping and speeding up the movement of emerging economies along the IDP curve (Narula, 1996; Dunning et al., 1997; Child and Rodrigues, 2005). This seems to be the case in China, where the "Go Global" policy and the expansion of state-owned firms to foreign markets have enabled a rapid move towards a positive outward positioning. The Korean case is one of the most successful industrial catch-up stories among the late industrialising countries. The role of the state in designing policies to enhance the country's technological capabilities and hence provide international competitiveness reinforces the point raised by the IDP approach regarding the increasing role of governments in the process of generating and attracting FDI (Chang, 2007). In Brazil only recently we can observe some involvement of the state in the internationalisation of domestic firms - with BNDES providing funds and even taking shares in some internationalising companies. Also, in recent years diaspora investments have been viewed negatively, because of their impact on domestic employment. The limited international expansion of Brazilian firms is also a result of this perspective.

Second, the perpetuation of resource-intensive industries as the prominent foreign investors from Brazil indicates that there has been little change in the country's (and firms') OLI advantages. It might be that Brazil, through equivocal policies, did not successfully generate enhanced 'created assets' that enable firms to evolve in the productive chain towards more complex industries. As a consequence, the country is moving slowly along the IDP graph. An active innovation policy, which could be implemented in association with a well-structured policy on competitive expansion, would probably improve the situation. There seems to be a growing interest in this direction, and some recent policies in Brazil provide firms with financial support for innovation and external ventures. 
Brazilian outward investments continue their upward trend. Flows in 2008 reached USD 20.4 billion, a 190 percent growth over the previous year (CEPAL, 2008). Acquisitions have been numerous in recent years, showing the advance of Brazilian businesses in foreign markets and increasingly into developed markets. The main investing sectors remain the same. They rely on the competitive advantages that are their main strength and reproduce the historical division of tasks among capital ownership that has been long established in the industrial pattern. However, it is noticeable that innovation (in products, processes, and management) plays a growing role in the international expansion of Brazil's largest multinationals. This stresses the importance of an innovation strategy.

To summarise, and to respond to the chapter's central question, it is reasonable to affirm that the pattern and amount of both inward and outward FDI in Brazil are the expression of the economic structure that has been developed since its early industrialisation years. Despite the emphasis of both foreign and domestic firms on the domestic market, recently Brazilian firms have made greater efforts to invest overseas (Iglesias and Veiga, 2002; FDC and CPII, 2007). Their success will depend to a large extent on how government policies and incentives help to reshape the patterns of competition, technological change, and (foreign and domestic) investments. A closer observation of the results obtained from this foreign incursion will indicate the effectiveness of these attempts and the problems faced by these firms, and will most certainly reveal interesting aspects of Brazilian internationalisation. Once more, it is worth noticing the influence that government policies, both past and present, have in shaping the country's international expansion. This answers another question raised by this thesis, regarding the role of governmental support and stimulus in the establishment of national global players. We believe that coordinated government action, based on policies that enhance the competitiveness of domestic firms, with a strong emphasis on innovation and capability strengthening, would positively influence the dynamics of Brazilian outward FDI. 


\section{APPENDIX: Estimation Results}

Below are the summary results of the estimation, using STATA 8:

\section{Coefficients}

\begin{tabular}{|l|l|l|l|l|}
\hline NOI pc & Coefficient & Std. error & $\mathrm{t}$ & $\mathrm{P}>\mathrm{t}$ \\
\hline GNIpcap & -.5831228 & .1864185 & -3.13 & 0.005 \\
\hline GNIpcap $^{2}$ & .0000724 & .0000282 & 2.56 & 0.017 \\
\hline Constant & 921.349 & 279.5511 & 3.3 & 0.003 \\
\hline
\end{tabular}

Dependent Variable: NOI per capita

\section{Model Summary}

\begin{tabular}{|l|l|l|l|l|}
\hline Observations & $\mathrm{F}(2,23)$ & Prob $>\mathrm{F}$ & $\mathrm{R}^{2}$ & Adj $\mathrm{R}^{2}$ \\
\hline 26 & 10.06 & 0.007 & 0.4667 & 0.4203 \\
\hline
\end{tabular}

\section{Correlations}

\begin{tabular}{|l|l|l|}
\hline & GNIpcap & GNIpcap $^{2}$ \\
\hline NOI & -0.5606 & -0.4897 \\
\hline GNIpcap & - & 0.9867 \\
\hline
\end{tabular}




\section{Chapter 2 - The Global Players Survey: Methodological NOTES AND GENERAL FINDINGS ON THE INTERNATIONALISATION Process OF BRAZILIAN Firms ${ }^{5}$}

\subsection{Introduction}

The foreign investments of Brazilian firms have gained importance in recent years, but many questions remain unanswered regarding their determinants, their patterns, and in particular the main competitive assets that enable the establishment of Brazilian firms in foreign markets. The main purpose of our research is to understand how the capabilities accumulated by Brazilian firms since the industrialisation period are used as competitive assets overseas. That is, what are Brazilian firms looking for in overseas markets? To answer our main questions we will consider a specific set of firm-level data.

The purpose of this chapter is to describe the database that will be applied in the empirical analysis of Brazilian FDI. Fundação Dom Cabral, a business school in Minas Gerais (Brazil) carried out the 'Global Players' survey in 2007. The survey approaches internationalisation in a broad sense. The first level is achieved via exports and evolves towards more complex activities, following the patterns proposed by the Uppsala model of internationalisation (Johanson and Vahlne, 1977). Together with knowledge from different (mostly secondary) sources on the international operations of Brazilian firms, this survey is the key data source for this and the following chapters.

Increasingly, Brazilian firms are intensifying their international presence and investing strongly overseas. Some firms have already established global prestige, becoming well-known Brazilian multinationals; these include Vale, Gerdau, Petrobrás, Embraer, Natura, Marcopolo, and Odebrecht (van Agtmael, 2007; Bartlett and Goshal, 2000). The first three of these firms are present in the UNCTAD top 100 multinational companies from developing countries (UNCTAD, 2009) and in other listings of emerging global players (BCG, 2009).

Brazilian firms are reaching overseas markets in a large variety of ways. Acquisitions have often been used to reach overseas markets, especially in developed countries. In 2007, for instance, JBS-Friboi acquired Swift Armor, becoming the world's largest meat processor (CEPAL, 2008). Gerdau also carried out important acquisitions in the northern hemisphere and dramatically increased its global presence. However, there are several other potentially successful ways in which firms are gaining ground in foreign markets.

\footnotetext{
5 This chapter is based on Carvalho, F. et al., Global players from Brazil: Drivers and challenges in the internationalization process of Brazilian multinationals. Paper presented at the Annual AIB Meeting, Rio de Janeiro, Brazil, June 25-29, 2010.
} 
The increasing internationalisation of Brazilian firms increases the need to better understand the processes involved. From this many questions emerge, such as: how do firms enter foreign markets? What activities are carried out abroad? Why do firms decide to internationalise? What are the main obstacles impeding internationalisation? Are firms obtaining the expected benefits from internationalisation? These questions were the guidelines to the development of the Global Players survey.

This chapter is structured as follows. The following section describes the methodological aspects of the survey, and Section 2.3 focuses on the modes of entry and destination of Brazilian investments. Section 2.4 deals with the main obstacles to internationalisation, as perceived by Brazilian firms. Section 2.5 provides some final remarks.

\subsection{Methodology}

Surveys are a widely used research tool in social sciences, applied in order to allow researchers to generalize about a large population by studying a small portion of that population (Rea and Parker, 2005).

The 'Global Players from Emerging Markets' survey is a comprehensive effort to understand the internationalisation of Brazilian firms.. The target sample was the thousand largest domestic firms in Brazil, Argentina, Chile, and Mexico ${ }^{6}$. This constitutes a simple random sample, once there was a previous choice for a certain firm size. There was no discrimination regarding foreign activities of these companies since finding out the types of foreign insertion is one of the main drivers of the survey. However, it is expected that larger firms have a higher rate of internationalisation (either through exports or direct investments) than smaller firms.

Surveys also reflect the perceptions of respondents. The Global Players Survey aimed to gather information on the perception of business leaders - usually the CEOs or presidents of the companies that answered to the questionnaire - regarding the (prospective or actual) international insertion of the companies they manage.

The Global Players questionnaire is divided into three main categories: 1- general information on the respondent and the firm (sector of operation, revenues and assets, capital governance); 2- characteristics of international operations (determinants, locations, mode of entry, main competitive advantages, largest-profit market), and 3- reasons for not investing overseas (information on previous activities, reasons for giving up, future plans). The information is self-reported and most questions apply a Likert scale to rate the respondents' levels of agreement with the survey's statements. A translation to the English language of the Global Players questionnaire is available in Appendix A at the end of the thesis.

\footnotetext{
${ }^{6}$ The response rates for Argentina and Chile were quite low (less than 25 questionnaires) and there were no responses for Mexico. Also, due to the purpose of the thesis, we will use only responses from Brazilian firms.
} 
The underlying theoretical approach utilised as a guideline of the survey is the Uppsala model of internationalisation, which posits that firms will internationalise in stages, increasing their foreign-market commitment as their knowledge intensifies, thereby reducing uncertainty and information imperfection (Johanson and Vahlne, 1977). The idea of stages of internationalisation also considers psychic distance as a barrier to foreign expansion; thus, expansion to further, less-similar markets would occur after some knowledge and experience has been accumulated.

Internationalisation is, therefore, a gradual movement: from exports and exportsupport operations (sales, post-sales, marketing) to more committed forms of expansion such as procurement (closer relations with suppliers and/or customers), complete or incomplete manufacturing, and R\&D.

In this thesis, we focus on the information obtained for Brazilian firms; the response rate was around 10 percent, with 93 valid questionnaires returned. This might seem too small a sample, but we must acknowledge that the number of Brazilian firms that are truly internationalised is rather low. CEOs who did not relate to the main subject of the questionnaire might have not felt compelled to respond to it. Of the responding firms, 78 percent have some activity abroad, 13.9 percent have none, and 23 percent of those with no operations abroad have abandoned previous attempts to internationalise.

In order to account for the possibility of bias towards internationalised firms in the sample, we carried out a non-response analysis of 20 companies among the 500 largest companies listed at the ranking "Exame Melhores e Maiores". We looked at companies' reports and websites in order to gather data relative to their international operations, in addition to data on sales revenues, assets and employees that were available at the ranking. The sample presented similar means of total sales revenues, and similar shares of foreign activities. The next section presents the main results from the Global Players survey.

\subsection{Characteristics of International Activities of Brazilian Firms}

The actual number of Brazilian multinationals is unclear, and existing statistics on the subject are misleading. The Central Bank database shows that around 800 firms report some foreign investment, but this number might be inflated by the fiscal-driven investments of individuals who are registered as juridical persons. The number of firms with significant foreign investment is much smaller. Some studies believe the figure is around 100 while others put it below thirty (De Negri and Salerno, 2005; CEPAL, 2009; Fleury and Fleury, 2009). The 2007 ranking of Brazilian firms by their foreign assets revealed that Brazilian investments abroad are concentrated in a few firms, with the three largest investors accounting for 75 percent of foreign assets of the largest 20 Brazilian multinationals (FDC and CPII, 2007; FDC, 2008). In summary, there are around fifty significant Brazilian players in the international scenario, and an increasing number of firms are taking their first steps towards internationalisation. 
With this in mind, the sample of 93 firms that answered the Global Players survey is quite representative, considering the population of Brazilian firms with international operations. The foreign assets reported by the respondents represent around 25 percent of the total foreign assets owned by Brazilian firms in 2006; the total is USD 22 billion, according to UNCTAD (UNCTAD, 2007).

The responding firms are mainly from southern states: 78.5 percent of firms are from the southeast or south. Sao Paulo has the most firms in the survey, 37.6 percent, followed by Santa Catarina, Minas Gerais, Rio Grande do Sul, and Paraná.

The firms in the sample are from a wide range of industrial sectors, including food and beverages (9.7\%), agricultural products $(7.5 \%)$, and construction/construction materials (11.8\%). The service sectors have a significant share in the sample (32\%). Regarding size, 92 percent of firms in the sample have more than 500 employees. The chemical/petrochemical/oil, gas, and energy industries represent a total of 8.6 percent of the sample (see Table 2.1).

Table 2.1: Sector distribution of firms in sample

\begin{tabular}{ll}
\hline Sector & Number firms \\
\hline Food \& Beverages & 9 \\
Wholesale \& Retail & 8 \\
Construction & 6 \\
Automotive \& Aerospace & 5 \\
Rubber \& Plastic & 1 \\
Construction Materials & 5 \\
Pulp \& Paper & 3 \\
Textile, Apparel, \& Shoes & 6 \\
Electronic Equipment & 3 \\
Pharmaceutical, Hygiene, \& Cosmetics & 2 \\
Metal-mechanics & 1 \\
Chemical \& Petrochemical & 6 \\
Mineral Extraction, Oil, \& Gas & 2 \\
Agroindustry & 7 \\
Communication Services & 2 \\
Transport Services & 7 \\
Financial Services & 3 \\
Consulting, Auditing, Advertising, \& Other Professional & \\
Services & 4 \\
Metallurgy \& Quarrying & 6 \\
Technology (IT) & 1 \\
Energy & 6 \\
\hline
\end{tabular}

Source: Compiled by author using data from Global Players survey, 2007

\subsubsection{Geographic Dispersion of Brazilian Investments}

Brazilian firms have a historical preference for geographic and psychic proximity in their main target markets (Villela, 1983; Rocha, 2002). The early overseas investments in the 1980s showed a strategic preference for Latin America. Metal- 
mechanics, construction, and engineering usually went to South America; North America was the preferred destination for investments from the oil industry (Lopez, 1999).

The motivations for these choices were geographical proximity, strategic presence, and cultural similarity. Hence, physical and cultural proximity were important features when firms made their first movements overseas, in line with the assumptions of the Uppsala theory of internationalisation. The recent information from Global Players on investment destinations shows that this preference still applies.

South and Central America is the preferred region of Brazilian investors, accounting for the largest share of investments: 23.2 percent. The European Union, with 19.2 percent of investments, has the second largest share. Portugal has a strong cultural similarity to Brazil and is an important European destination for Brazilian investments. Asia receives 13.3 percent of Brazilian investments and is a continent of growing interest. Some strategic partnerships have been made between local and Brazilian firms and production facilities have been set up (such as Sadia in Russia ${ }^{7}$, and Marcopolo $^{8}$ and Embraer ${ }^{9}$ in China) (see Fig. 2.1).

Figure 2.1: Distribution of foreign operations per region

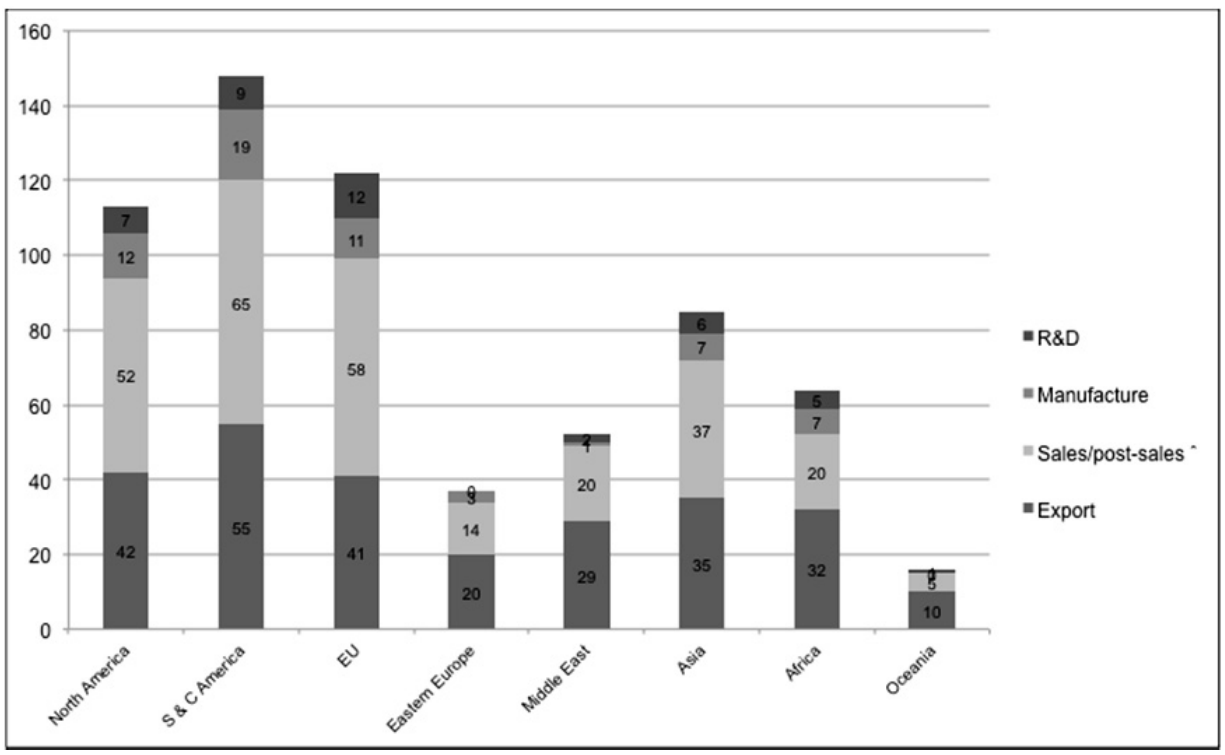

Source: Compiled by author using data from Global Players survey, 2007.

$\wedge$ Sales and post-sales activities include marketing and procurement.

\footnotetext{
7 The joint venture was terminated in 2009 after the company suffered huge losses during the financial crisis.

${ }^{8}$ Production was paralysed by the financial crisis in 2009 .

${ }_{9}$ Embraer has recently decided to withdraw its investments in China and will no longer assemble aircraft there.
} 
The location behaviour is in line with the location patterns of multinational corporations in general. The literature has observed that multinationals have a tendency to cluster the bulk of their investments in neighbouring regions, particularly at the earlier stages of internationalisation (Goldstein, 2007). Scholars have long referred to the movement of developed-country multinationals as a 'triadisation' (Chesnais, 1996) or have claimed that the globalisation process is more a regionalisation (Rugman and Doh, 2008). In this sense, Brazilian investments behave similarly to those of most multinationals around the globe, be they conventional or emerging multinationals.

South American countries are important trade partners for Brazil, especially with the establishment of free-trade agreements such as the Mercosul. North America has the advantage over other developed locations of being relatively close, implying cheaper transportation costs. Moreover, the Americas receive the most investment also because of the presence of fiscal havens, which historically have received a significant share of Brazilian FDI (Lopez, 1999; Villela, 1983).

Not surprisingly, the American continent also represents the largest share of foreign revenues from Brazilian firms investing abroad. North America accounts for 22.7 percent, and South and Central America (except Brazil) for 32.3 percent. Revenues from the European Union represent 18.3 percent. It is worth mentioning that the question on revenues does not discriminate between revenues of foreign subsidiaries and exports; therefore, these numbers represent international operations in a broad sense.

Exports are the main activities that Brazilian firms carry out overseas, which indicates that most firms in the sample are taking their first steps towards international expansion. Operations that support export activities, such as sales offices, post-sales services, marketing, and procurement are also significant. Productive and R\&D activities represent a small share of Brazilian investments. The distribution of foreign activities shown in Fig. 2 has a shape that evokes the gradualism observed by the Swedish school (Johanson and Vahlne, 1977).

Manufacturing activities are gaining importance as more and more firms pursue the internationalisation of their production facilities. More than one third of the respondents have some kind of manufacturing facility, either complete or partial. South American countries are again the main destination for this type of investment (31.7\%), followed by North America (20\%), and the European Union. 
Figure 2.2: Activities carried out abroad (\%)

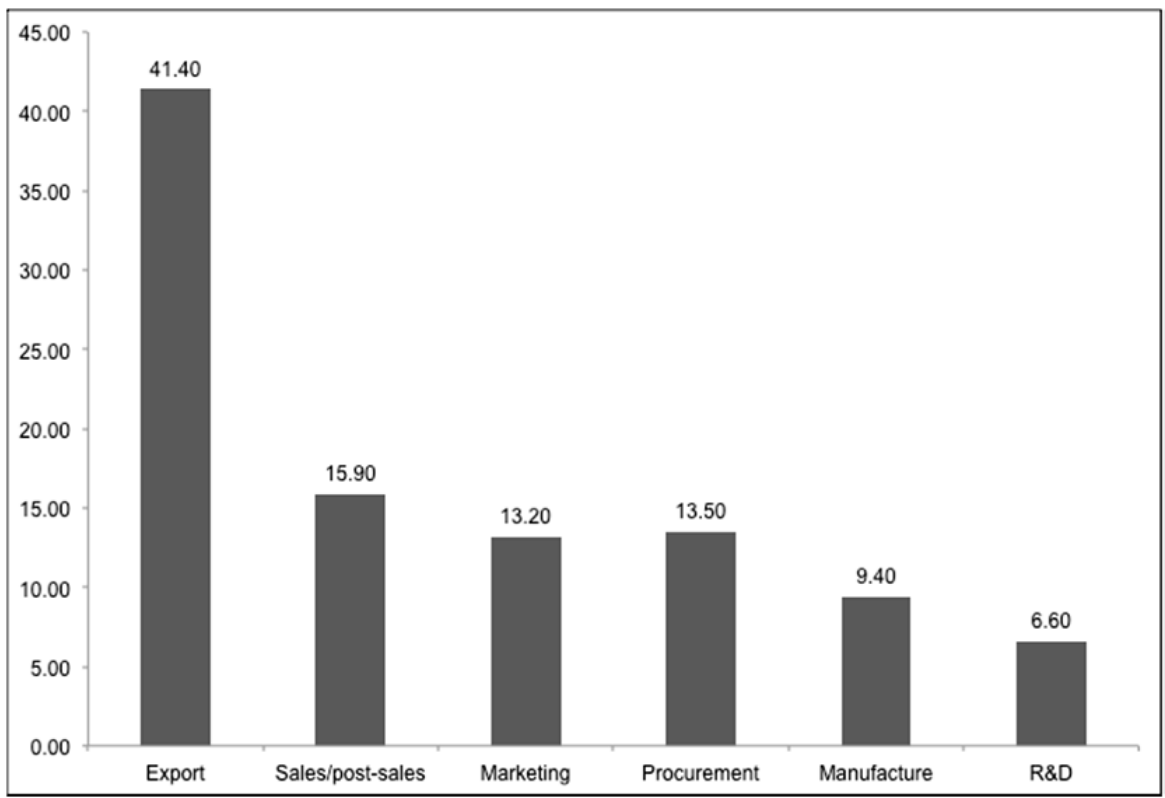

Source: Compiled by author using data from Global Players survey, 2007.

It is interesting to note that most $\mathrm{R} \& \mathrm{D}$ activities carried out by Brazilian firms abroad had European countries as their destination (28.5\%), whereas North and South America are the preferred regions for establishing manufacturing facilities $(20 \%$ and $31.7 \%$, respectively). In Europe, around 22 percent of firms are from the food sector, a sector in which Brazilian firms have intensive R\&D expenditure (Carvalho, 2010). In North America, firms concentrate on automotive and aerospace, and on textile and clothing (29.6\% in total). South America has the most diversified set of investments, but agro-industry and construction materials are the leading sectors $(22.6 \%$ each).

To summarise, the survey indicates that Brazilian firms are internationalising in various destinations, activities, and sectors, intensifying a trend that started quietly in the 1970s. The next sections will describe the modes of entry of Brazilian investments and highlight the determinants and obstacles of the internationalisation.

\subsubsection{Modes of Foreign Entry}

The entry mode into a foreign market is an important strategic decision that determines, among other things, the resources committed to a specific investment and the depth of the commitment. The entry mode is influenced by the same factors that influence investments per se: firm ownership advantages, location advantages of a market, and internalisation advantages of keeping the business under the firm's control 
(Dunning, 1993). In this sense, whether the firm decides to export to a foreign market, to establish a partnership with a local entrepreneur, or to enter the market with a new business reveals much about its objective in that market.

Multinationals from emerging markets have recently revealed a preference for entering markets (especially developed markets) via acquisitions. Their motivation might be to find markets, to take over established brands, to access existing distribution channels, or especially to access existing technology and scientific knowledge (Goldstein, 2007).

For the Brazilian firms in the survey, the preferred mode of entry is Greenfield investments $(34.4 \%)$, followed by alliances and partnerships (25.8\%). Acquisitions and joint ventures come in third, with 16.6 percent and 16.7 percent, respectively. Majority-shared and equally shared joint ventures are preferred over minority ones. Most Greenfield investments take place in North America (31\%), followed by South America (23\%), and the European Union (15\%) (see Fig. 2.3).

Franchising, mergers, and licensing were the modes of entry of less than 5 percent of respondents. An earlier study on the ownership structure of Brazilian investments abroad (Barreto and Rocha, 2002) revealed a cultural preference for wholly owned subsidiaries overseas. Such a preference is, in fact, characteristic of all multinational enterprises.

Figure 2.3: Brazilian investments: Modes of entry by region of destination

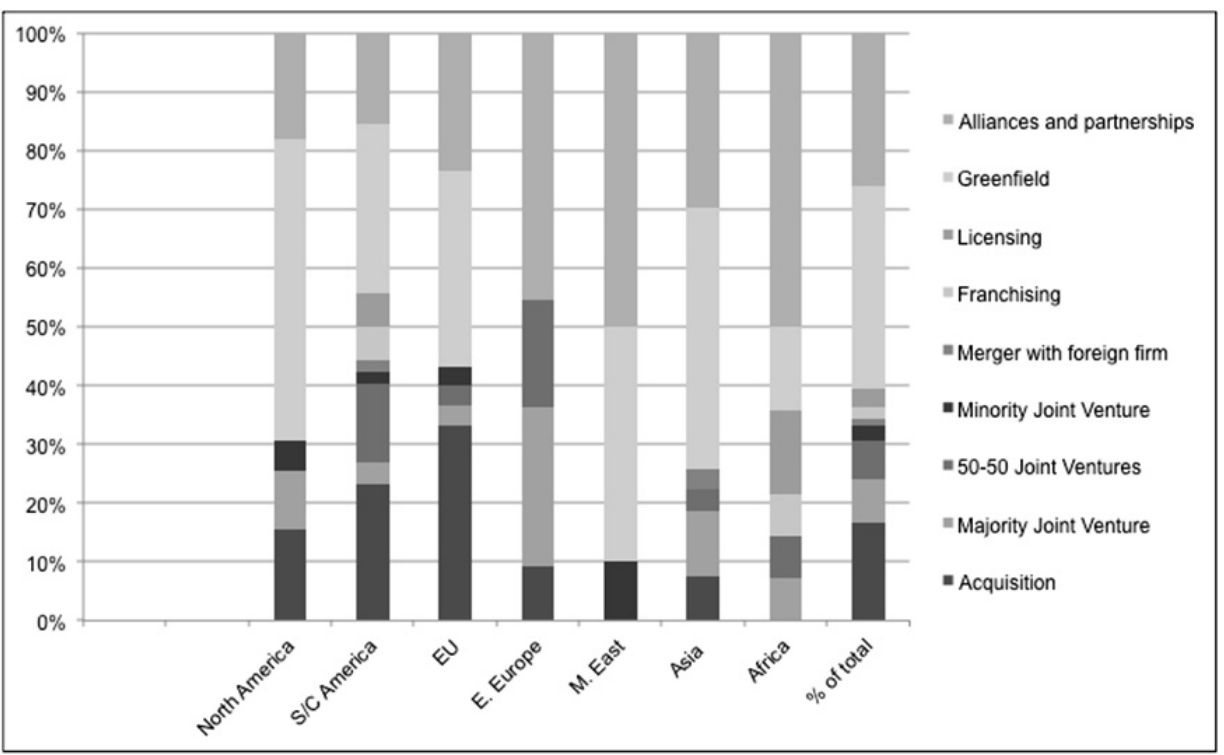

Source: Compiled by author using data from Global Players survey, 2007. 
Overseas acquisitions have gained strength in recent years, especially because of the stabilisation of the Brazilian economy and the appreciation of the Brazilian currency against the dollar. The latter has made acquisitions much cheaper, especially acquisitions of North American firms (see Table 2.2). Large firms with an international strategy have taken this opportunity to expand market range and to access natural resources not available in the domestic market; for example, Vale's acquisition of Inco Steel in Canada, Votorantim's acquisition of US Zinc, and Gerdau's acquisition of Chaparral Steel (CEPAL, 2008).

Table 2.2: Main acquisitions from Brazilian firms abroad, 2007/2008

\begin{tabular}{|c|c|c|c|c|c|}
\hline Year & Acquiring & Acquired & Country & Value* & Sector \\
\hline \multirow[t]{10}{*}{2007} & Gerdau & Chaparral Steel & USA & 3.974 & Steel \\
\hline & Gerdau & Qanex Corp & USA & 1.458 & Metallurgy \\
\hline & JBS Friboi & Swift Co. & USA & 1.400 & Food \\
\hline & GP Invest & Drilling Rights and E\&P & $\begin{array}{l}\text { Argentina, } \\
\text { others }\end{array}$ & 1.000 & Oil \\
\hline & Vale & AMCI Australia & Australia & 786 & Mining \\
\hline & Votorantim & Acerias Paz del Rio & Colombia & 494 & Recycling \\
\hline & JBS Friboi & Inalca & Italy & 329 & Food \\
\hline & Votorantim & US Zinc Group & USA & 295 & Steel \\
\hline & Gerdau & Grupo Industrial Feld & Mexico & 259 & Steel \\
\hline & Gerdau and Kalyiani & SJK & India & 170 & Steel \\
\hline \multirow[t]{5}{*}{2008} & Magnesita & LWB Refractories & Germany & 952 & Manufacturing \\
\hline & JBS Friboi & Smithfield Beef Group Inc & USA & 565 & Food \\
\hline & Gerdau & Sidenor Spain & Spain & 287 & Metallurgy \\
\hline & JBS Friboi & Tasman Group & Australia & 148 & Food \\
\hline & Votorantim & Cia Minera Atacocha & Mexico & 145 & Mining \\
\hline
\end{tabular}

Source: CEPAL, Foreign Direct Investment in Latin America and the Caribbean, 2008, 2009.

* Values in USD million

\subsubsection{Determinants of Outward Investment}

According to the survey, access to new markets was the main determinant for the international operations of Brazilian firms, with the second being the desire of shareholders and top managers. Third is the need to reduce the risk of operating in a single market by geographic diversification. The risks of operating solely in the domestic market are the danger of an economic slowdown and the increasing competition from abroad.

Some aspects of the Brazilian economy played a crucial role in the growth in outward FDI. One factor is that, for several years, the growth rates of the Brazilian economy were not sufficient to sustain the expansion of markets. During the economic slowdown of the 1980s, firms had to look for alternative sources of growth, such as foreign markets, in order to survive. At the end of the 1990s, growth rates were again low. 
The intensification in competition from foreign firms from the 1990s was another driver for the internationalisation of Brazilian firms. Competition grew stronger with economic openness to foreign products and with the massive entry of FDI (SOBEET, 2007). This competition impacted the strategic decisions of firms, making their expansion into international markets a necessity rather than an option.

Similarly, for individual managers and shareholders, internationalisation is a positive strategy because it strengthens the reputation of the firm in the local market. This is desirable at a time of tight competition with major brands in both the global and home markets.

The sample shows that the need to overcome trade barriers is not a main driver for the internationalisation of Brazilian firms. The importance attributed to this factor was quite low, an average of 2.7. However, non-investing firms ranked the same trade barriers fifth among the main barriers to internationalisation.

To have a clearer view of the determinants of internationalisation, we grouped the motivations suggested in the survey into five categories: technology-seeking (TECSEEK), technology-exploiting (TECHEX), resource-seeking (RESEEK), efficiency-seeking (EFISEEK), and market-seeking (MKTSEEK).

The highest-scored determinant was technology-exploiting. The statements concerning this determinant referred to "the opportunity to exploit internationally the technological and managerial capabilities of the firm", "the opportunity to exploit product differentiation capabilities", and "the opportunity to exploit firms' brands and patents internationally". In the sample, 31 percent of firms reported being drawn by motivations of this nature. Market-seeking motivations were the second strongest determinant of Brazilian operations abroad, with 22.6 percent (see Fig. 2.4). Resourceseeking motivations were the least important. The firms reported that access to natural resources was their strongest competitive advantage overseas, which explains the low need to search for such assets abroad. 
Figure 2.4: Determinants of internationalisation - number of firms

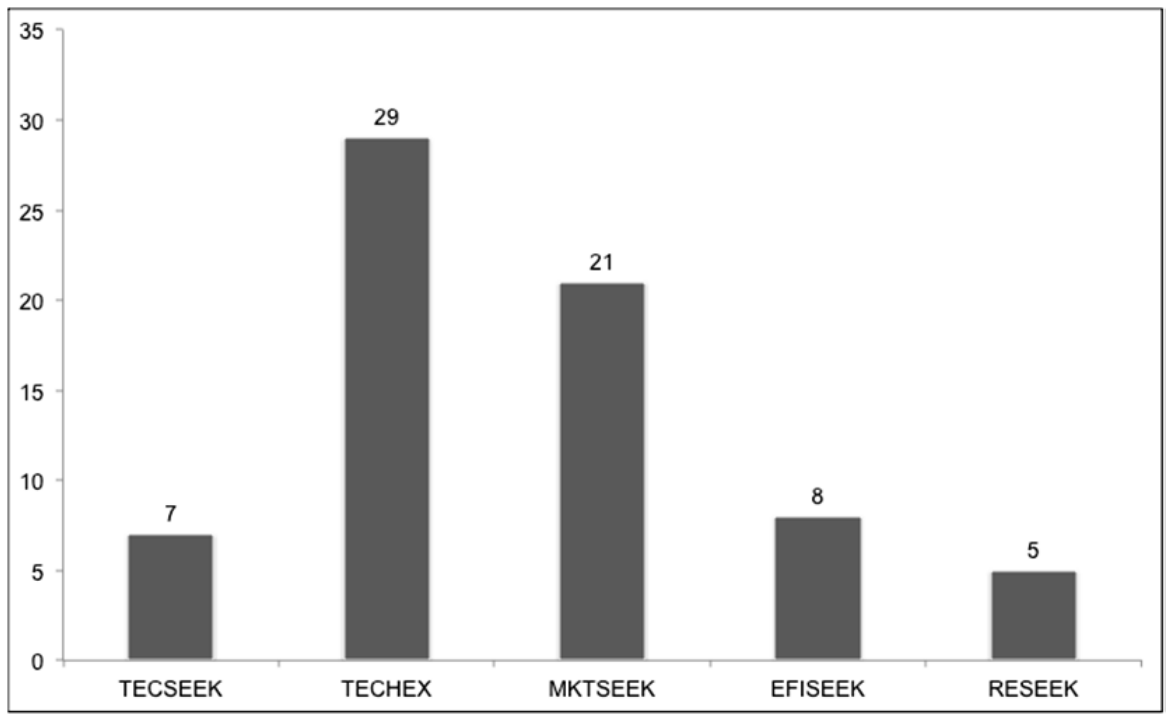

Source: Compiled by author using data from Global Players survey, 2007.

The motivation 'learning of new competencies' had the third-highest rank. This reflects the still hesitant attitude of Brazilian firms towards technology-seeking vis-à-vis technology-exploiting FDI. The latter has a strong presence among Brazilian investments. This suggests that knowing how to do business in adverse environments such as emerging markets is still a strong competitive advantage of Brazilian firms, and that more and more Brazilian firms are going overseas in a search for this advantage.

The results presented by the firms from the sample are somewhat different from what has been observed as the determinants for the internationalisation of firms from emerging markets. Investments from countries such as China seem to be oriented by the search of competitive assets (mainly technology, know-how) especially if the host market is a developed country. In this sense, the case of Brazilian firms seems to be different than the usual. Understanding more in depth such specificities of the Brazilian case is, in fact, the purpose of this thesis, and its idiosyncrasies will be better explored in the following chapters.

\subsubsection{Technology, Competitiveness, and Internationalisation}

According to Dunning (1993: 287), "technology (...) determines the way in which natural resources and created assets are managed and utilised to produce valued outputs." Technological capabilities are undoubtedly a central ingredient in economic development and in the success of firms. Technology is therefore an important component of the ownership advantages (O) of firms. 
Technology is analysed in the internationalisation process from two perspectives: as a key competitive asset, and as an object of pursuit to augment a portfolio of physical assets and human competences (Dunning and Lundan, 2008). The Global Players survey discusses both dimensions and their relationship to the internationalisation of Brazilian firms. This section investigates how firms evaluate technological capabilities and their strategic value as a competitive asset in foreign markets.

Firms were asked about their competitive advantages vis-à-vis those of their main international competitors. Twenty-one competitive advantages were listed, and respondents gave a value from 1 (internationally very weak) to 6 (internationally very strong). Table 2.3 below lists the competitive advantages.

Table 2.3: International competitive advantages of firms

\begin{tabular}{ll}
\hline Label & Competitive Advantage \\
\hline TECH & Modern, efficient equipment and plants \\
TECH & Innovation capability \\
TECH & Better support services \\
TECH & Competence in international niche markets \\
MGM & Competence in international supply chain \\
MGM & Capability to respond to expectations of foreign customers \\
BRAND & Brand international reputation \\
EFFIC & Scale advantages \\
EFFIC & Vertical control of value chain \\
EFFIC & Synergy in business activities within group \\
EFFIC & Supporting services and resources from holding firm \\
EFFIC & Access to lower-cost capital \\
EM & Advantage for operation in emerging-market conditions \\
LABOR & Qualified labour at competitive cost \\
LABOR & Access to managerial, technical, or scientific pool of talent \\
NRES & Access to natural resources at lower cost or under favourable \\
& conditions \\
\hline
\end{tabular}

The competitive advantages were grouped according to common features. These groups are: labour capabilities (LABORCAP), technological capabilities (TECH), ability to operate in emerging-market conditions (EM), brand advantages (BRAND), natural resources (NATRES), efficiency advantages (EFFIC), and managerial capabilities (MGM). The Likert values were separated into two response categories: strong capability and weak capability.

A strong capability is a value higher than three on the Likert scale. The distribution of capabilities among the firms is shown in Figure 2.5. 
Figure 2.5: Competitive advantages of Brazilian firms

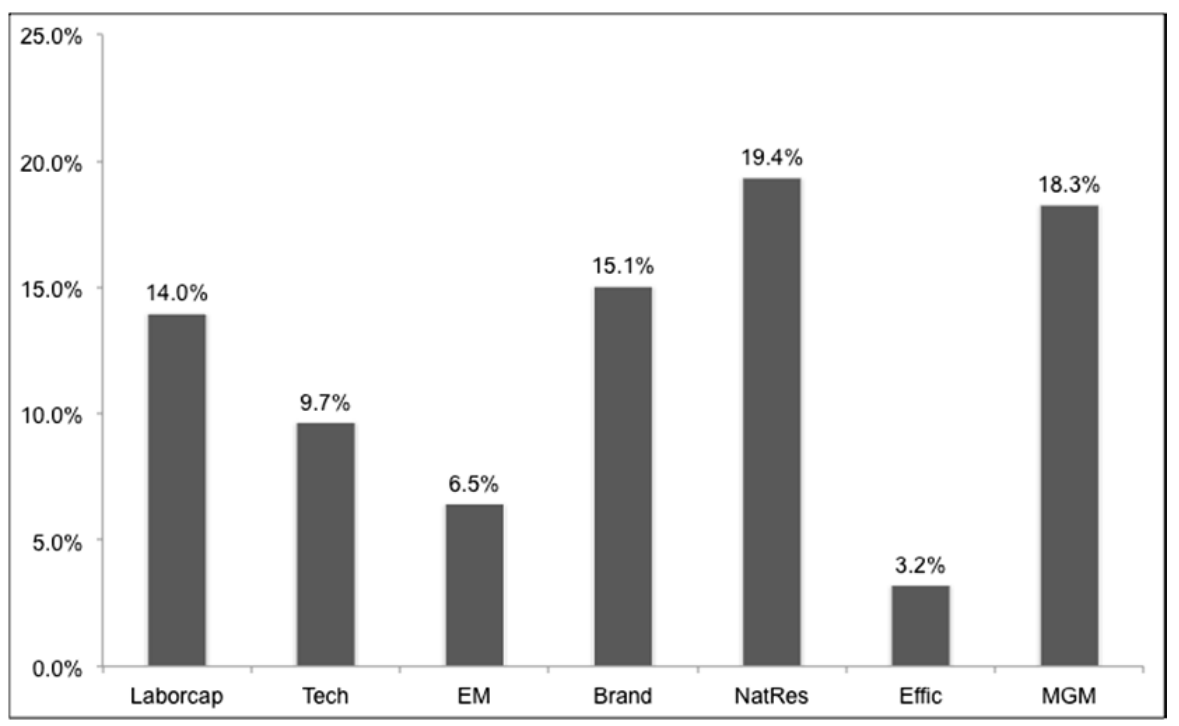

Source: Compiled by author using data from Global Players survey, 2007. Note: Capability is possessed if response is higher than three.

The survey respondents identified their access to natural resources as their strongest competitive advantage abroad. This was followed by managerial competences and brand-related advantages. This indicates that Brazilian firms rely on their brasilidade, i.e. the Brazilian way to do business. This is especially true when firms operate in similar markets, where they can replicate their ability to deal with instability and unexpectedness, acquired during the economically difficult years (Villela, 1983). It is also a consequence of South and Central American markets being the most important source of foreign revenue.

The importance of natural resources is a consequence of Brazil's size and rich natural diversity. It also derives from the strong share of firms with export activities in our sample. Exports accounted for 41 percent of all activities reported. It is worth noting that natural resource-related exports (commodities) account for more than 40 percent of total Brazilian exports (Almeida, 2009).

Firms were also asked about the main strategy behind the international expansion, and had to rank the top two. The leading strategy was to boost comparative advantages through exports; the second was the search for new knowledge. This is in contrast to the determinants of internationalisation, which showed low levels for technology-seeking. The search for technological assets that are not available to firms in their domestic markets is an important driver of foreign investment in general, and has become a central motivation for the internationalisation of firms from emerging markets (Mathews, 2002; Dunning et al., 2008; Dunning and Lundan, 2008). Technologyseeking investments account for only 7.2 percent of our sample (Fig. 2.4), but the re- 
cent increase in foreign acquisitions might be a signal that more investors are seeking to augment their strategic position through such investments.

To summarise, the Global Players survey highlights some aspects of the competitiveness of Brazilian investors. The results are broad and include export activities. The survey reveals that investors do not acknowledge strong, consolidated capabilities. On the other hand, few firms reported a technology-seeking motivation for internationalisation. In the following chapters we will look at the determinants of internationalisation specifically for productive activities, to find the patterns being followed.

\subsection{Obstacles to Internationalisation: Why do so Few Firms Venture Abroad?}

For an emerging market such as Brazil, it is important to understand why firms do not internationalise more and with more commitment. Few firms in Brazil go beyond internationalisation via exports. In some cases, internationalisation might not be profitable or feasible because of the nature of the business. In other cases, it might not be the desire of the owners/shareholders, or the domestic environment might fulfil the firm's requirements and provide a satisfactory turnover. Moreover, economic conditions, both locally and internationally, might make it difficult for some firms to expand overseas.

In the survey sample, seventeen firms reported no international activity; three reported having abandoned international ventures. 
Table 2.4: Main barriers to internationalisation

\begin{tabular}{ll}
\hline Barrier & Mode \\
\hline High tax costs from Brazil & 6 \\
Domestic market fully satisfies growth expectations of firm & 4 \\
High financial costs to finance operations & 4 \\
High logistics costs & 5 \\
Trade barriers from abroad & 5 \\
Unprepared human resources & 4 \\
Lack of government incentives & 4 \\
Unfavorable exchange rate & $1,3,5$ \\
Lack of experience in internationalization & $1,3,5$ \\
Problems to find partners, distribution channels and/or clients & 4 \\
Non-trade barriers & 2,4 \\
Language barriers & $1,2,5$ \\
Insufficient financial resources & 4 \\
Labour issues (costs, turnover, strikes, etc.) & 2 \\
High production costs vis-à-vis foreign competitors & 2,3 \\
Unawareness or negative image of Brazil abroad & $1,2,3$ \\
Lack capacity to supply foreign markets & 1,2 \\
Difficulty to supply specific product demands of international clients & 1 \\
Cultural barriers & 2 \\
Insufficient or inappropriate technological competences for foreign markets & 2 \\
\hline
\end{tabular}

Source: Compiled by author using data from Global Players survey, 2007. Obs: modes are the most frequent values responded by firms, ranging from 1-6.

The main obstacles to internationalisation reported by the respondent firms were the high tax costs from Brazil, high logistics costs and the difficulty to find human resources prepared to work abroad (Table 2.4). Amongst the reasons for abandoning foreign investments are changes in the company's internal priorities and the emergence of more interesting business opportunities in the domestic market. Again, the domestic-success argument is presented as an obstacle to internationalisation.

This raises some interesting aspects of the specific condition of firms in a country such as Brazil. First, there seem to be few incentives to invest abroad, and many firms from various sectors would rather wait for a stronger reason to internationalise. Second, there seems to be a lack of interest in venturing into overseas markets when the domestic one provides the dynamism that the firm needs. Another barrier to internationalisation is a lack of knowledge of foreign markets, their culture and consumer preferences, and the competition.

The hesitant movement of Brazilian firms towards global markets can be interpreted as an inheritance of the years of a economic closeness and self-centred economic growth, the characteristics of an inward-looking process of industrialisation. On the other hand, it also appears that for many businesses in Brazil, internationalisation is simply not the best option, since there are still numerous possibilities for sales and profit expansion. The case of internationalisation of Brazilian firms seems to be a double-edged sword, with some firms having being harnessed by the economic con- 
text in the past and others benefiting from this very same context. Nevertheless, the survey indicates that more and more firms are trying to overcome a national-centred vision and adapt their strategies in accordance with an increasingly competitive and globalised world. This is a feat worthy of notice, especially in a country as large and rich as Brazil.

\subsection{Discussion}

This chapter highlighted the general results of the Global Players survey, which investigated Brazilian firms from diverse sectors. It considered the main characteristics of their international expansion in the late 2000s, in terms of location, determinants, modes of entry, activities, and competitive advantages. The survey indicated that, although incipient, Brazilian firms are making stronger moves towards international markets. This chapter has provided a better understanding of where, why, and how these firms are internationalising.

Brazilian firms still prefer doing business in countries with a proximity to Brazil, geographically, culturally, or historically. However, more developed destinations are the recipients of more specialised activities such as R\&D. Exports are the main internationalisation strategy, but firms are increasingly making efforts to expand beyond exports. For these firms, Greenfield investments are the preferred mode of entry.

Technology-seeking investments are rather scarce, but firms acknowledge that the search for new knowledge is a major motivation for internationalisation. This may seem contradictory, but it signals that the search for new knowledge is now in the internationalisation agenda.

The increasing efforts to internationalise beyond exports have recently attracted the attention of the Brazilian government. The government has come to believe that internationalisation is positive for economic growth and development. For a long time it was believed that the only way to grow and develop was by increasing export efforts. A recent study by the Government's think tank IPEA has suggested that innovation and further levels of internationalisation improve firms' export performance, thereby legitimising economically the effort of internationalisation (Arbix et al., 2004).

An important consequence of this change of perspective is the recent government decision to support national conglomerates with funds from the Brazilian development bank, BNDES (Valor Econômico, 2010). The development bank had a direct or indirect role in some of the most important foreign acquisitions by large Brazilian groups, such as JBS Friboi, Bertin, and the merger of Sadia/Perdigão, all examples from the food industry (Almeida, 2009). The initiative shows that Brazil sees the internationalisation of domestic firms as a matter of economic development. However, the efforts are still far from the Chinese Go Global strategy (UNCTAD, 2006; Child and Rodrigues, 2005).

There are limitations in an analysis based on a survey. First, we cannot generalise the findings to all Brazilian firms that are pursuing international expansion. The small 
size of the sample is a limiting factor, especially for further empirical investigations. However, we believe that this sample is important more for its theoretical relevance than its statistical representativeness (Davidsson, 2005, cited in Arbaugh et al., 2008). Therefore, we believe this chapter offered new insights into the internationalisation process of Brazilian firms.

The next chapters will explore internationalisation, competitive assets, and technology in more depth. We will pay special attention to higher-value-added activities and to investments in developed locations; we will also try to relate higher levels of internationalisation to specific firm characteristics and assets. Our underlying goals are to place Brazilian FDI in the context of the recent wave of investments from other emerging countries and to search for similarities or differences in the approaches. 



\section{ChaPTER 3 - What Determines BraZiLian FDI? ASSESSING THE ROLE OF TECHNOLOGY IN THE RECENT WAVE OF INVESTMENTS FROM EMERging MULTinationals ${ }^{10}$}

\subsection{Introduction}

The internationalisation of firms from emerging markets has become a widely studied topic, with attention from several important publications, including special issues of the Journal of International Business Studies (2007), the Journal of International Management (2007), and the International Journal of Technology and Globalisation (2008). Recent books include Mathews (2002), Goldstein (2007), Sauvant (2008), Ramamurti and Singh (2009), and Casanova (2009). Many of these studies focus on Asian countries, with China being the most studied case.

The reason for the rise of interest is the growing dimension of the phenomenon of emerging FDI, which increased from USD 144 to 2288 billion from 1990 to 2007 (UNCTAD, 2008). The speed with which firms from emerging economies are spreading worldwide is unprecedented. It is occurring faster than predicted by traditional theories of internationalisation. Firms are expanding to different and distant markets and partnering with local producers (Embraer has a joint venture to produce aircraft in China; Sadia sells poultry in a similar arrangement with a Russian partner). They are also making bold acquisitions of established brands (such as IBM by Taiwanese Lenovo and Jaguar Land Rover by Indian Tata Motors) and key assets (Vale acquired Canadian Inco and now holds nickel reserves) (Goldstein, 2007; van Agtmael, 2007).

An aspect that has caught the attention of scholars in this field is the growing role of strategic asset-seeking investments as a key determinant for the internationalisation of many firms from emerging countries (Makino et al., 2002; Child and Rodrigues, 2005; Luo and Tung, 2007). For instance, firms from newly industrialising Asian countries (Korea and Taiwan first, followed by India and China) have based their internationalisation strategies on the search for competitive assets not yet possessed or fully leveraged (Dunning et al., 1997; Mathews, 2002).

This feature has changed the traditional timing for firms to become multinationals; some of them started their internationalisation without possessing the assets assumed necessary for ventures into overseas markets. This has prompted some scholars to claim the need for a new theory to explain emerging multinationals (Mathews, 2002, 2006; Child and Rodrigues, 2005). In particular, this new dynamic for emerging investments has brought about the rise of multinationals at earlier stages of the eco-

10 This chapter is based on Carvalho, F., Brazilian outward investments: Assessing the role of technology in the recent wave of emerging FDI. Paper presented at the 2009 Annual AIB Meeting, San Diego, CA, June 27-30. 
nomic development of their countries of origin (see Chapter 1 for a discussion of outward FDI and development). Firms from emerging countries still lack the strong Ownership advantages envisioned by the eclectic paradigm as a key determinant of foreign investments (Dunning and Lundan, 2008). They are internationalising anyway, and this early movement has led several authors to suggest that emerging multinationals follow a unique rationale, having a specific combination of resources and competences that demand special attention (Luo and Tung, 2007; Mathews, 2002, 2006; Child and Rodrigues, 2005; Goldstein, 2007).

The present chapter starts from the renewed discussion of the specificities of emerging multinationals, investigating the role of knowledge, in the form of technological and innovative assets, in the internationalisation of Brazilian firms. We investigate the main drivers of Brazilian investments abroad and how these drivers are related to either the exploitation of existing firm capabilities or the search for competitive assets not yet possessed - an issue still under discussion in the case of foreign investments from emerging multinationals. We also consider how market destination relates to competitive assets that are specific to emerging markets.

The internationalisation process of Brazilian firms is interesting. Brazil led the first movement of outward FDI from the emerging world in the 1980s, when such flows were small in comparison to total FDI levels. Since 1990, the level of outward investment from Brazil has stagnated to around $8 \%$ of its GDP. More recently, the world has witnessed occasional outstanding performance by Brazilian outward investments. For example, in 2006, huge acquisitions abroad raised the outward FDI flow to USD 28.2 billion, well above the inward flow (UNCTAD, 2007). In 2007, Brazil achieved an outward FDI flow of USD 7 billion, and its level of outwardinvestment stock has reached USD 180.9 billion in 2010 (UNCTAD, 2011). For comparison, in the same year Mexico had an outflow of USD 8.2, China 22.5, and India 13.7 billion. The outward FDI stocks of these countries in 2010 were, respectively, USD 66.1, 297.6, and 92.4 billion. China now is stronger in terms of the outward investments of its firms when compared to Brazil.

Studies of foreign investments of Brazilian firms are still scarce, especially those using firm-level data such as the Global Players survey. A larger firm-level study can contribute to the information provided by case studies of individual Brazilian firms. We believe that a survey covering a wide range of sectors will provide a better understanding of the determinants and main characteristics of Brazilian investments, leading to a clearer portrait of the country's pattern of outward investment.

The remainder of this chapter is divided into six sections. The next section presents the debate on emerging FDI and the different determinants of investments in the internationalisation of firms from emerging countries. Section 3.3 gives the hypotheses of the research. Section 3.4 describes the data and methods applied in the analysis, and Section 3.5 presents the empirical results. A final section gives the main conclusions. 


\subsection{Theoretical Background}

\subsubsection{Determinants of foreign investments by multinational firms}

One of the most applied frameworks to explain the internationalisation of firms, Dunning's eclectic paradigm discusses the key internationalisation drivers of a firm: the ownership of key assets, which can be tangible or intangible (O); the advantages of investing in certain locations (L); and the advantages of internalising (I) activities rather than transferring them to third parties. With these advantages, firms decide to internationalise their activities according to four main objectives: market-seeking, natural-resource-seeking, asset-seeking, or efficiency-seeking (Dunning and Lundan, 2008).

The determinants for the internationalisation of firms are drawn from their corporate strategies: some firms will pursue a market growth strategy, others will try to enhance technological capabilities; some firms may establish overseas in order to be closer to customers of have access to cheaper financial resources.

The possession of technological advantages is considered a key determinant for the growth of a firm, and it is also a central asset sustaining its foreign expansion. Technology has become a more and more crucial component of success, both domestically and internationally, as the global economy has moved further into the knowledge- and information-intensive era. Knowledge now plays a crucial role not only in technology-intensive sectors but also in traditional industries (Narula and Dunning, 2000). In general, large, successfully internationalised firms are those that accumulated technological capabilities that enabled their competitiveness and innovativeness (Dunning and Lundan, 2008). Traditional multinationals (those originating from developed countries, such as the USA, Japan, and Europe) have based their market expansion mainly on the exploitation of ownership advantages and in particular the possession of technological assets.

Recently, however, firms from less-developed economies have started their internationalisation at earlier stages and without the accumulated capabilities that had always featured in the expansion of traditional multinationals. This has renewed the interest of scholars in the rationale of such investments. Makino et al. (2002) have based their investigation into the determinants of outward FDI from Taiwan in the distinction between asset-seeking and asset-exploiting investments. This is, in fact, at the heart of the discussion about the increasing pace of emerging FDI (Mathews, 2006; Child and Rodrigues, 2005; Goldstein, 2007; Dunning et al., 2008).

The investments made by firms from emerging markets in the 1980s and 1990s were motivated by the need to expand markets, usually by profiting from accumulated specialised capabilities in markets similar to those of their countries of origin (Wells, 1983; Lall, 1983). More recently, these firms have not restricted their expansion to similar markets but have moved increasingly to more advanced locations (Makino et al., 2002; Child and Rodrigues, 2005; Mathews, 2006), suggesting a shift in motivation. It is because of the recent movement of Greenfield investments and the numer- 
ous acquisitions that emerging-market firms have carried out in developed countries that scholars are revisiting the debate on the determinants of emerging FDI.

The two main theories of internationalisation that build the framework used in the thesis have different standpoints to explain how firms chose a location to invest. To the eclectic paradigm, firms chose locations where they can most benefit from their advantages or benefit from the locational advantages (Cuervo-Cazurra, 2008). To the incremental internationalisation theory, firms would chose locations that are culturally and physically closer to minimize risks. The revision to this theory, however, affirms that internationalisation occurs now earlier and further due to the increasingly competitive environment in which firms from all countries are immersed. They are impelled to search for stronger competitive assets at earlier stages, because waiting to become large and competitive is no longer an option. Being part of an international network becomes imperative in the knowledge era, and early theories of staged internationalisation also complement their vision with what they refer to as the need to be part of such networks (Johanson and Vahlne, 2009). In this new world scenario, companies move to other markets to access competitive assets and not because of the possession of them.

Backwardness can therefore be seen as a driver of rather than a deterrent to investment abroad, which gained importance as a strategy of firms from emerging markets. As stated by Dunning and Narula (1996: 17), "precisely this insufficiency of Oadvantages needed to become global competitors in medium to high-technology intensive industries form another motivation to invest in economically advanced regions." In this sense, foreign investments from emerging economies are the strategic response of these firms to the evolution of globalised capitalism.

Furthermore, Dunning and Narula (1996) posit that the motivations leading to strategic asset-seeking FDI are changing as the world economy evolves. In addition to the search for knowledge-intensive assets, firms also engage in FDI to enhance their learning experiences, leading to a better knowledge of foreign markets and their consumer specificities (Dunning, 1998).

Another driver for technology-seeking investments is the possibility of technological spillovers. These are learning externalities that originate from the exchange of information, voluntary or not, between agents (firms in this case) in close proximity, arising from the public good that information has to some extent. Technological spillovers can take place in the host economy between local and foreign firms. Studies have emphasised the strong opportunities to learn and absorb technologies and technological capabilities when firms are in direct contact with agents in the foreign environment (Blomström and Kokko, 1998; Kinoshita, 2001). The boom in investments in Silicon Valley in the last decade is a good example of the attractiveness of a technologically intensive location because of the potential for spillovers. Technological spillovers are a good opportunity for firms from emerging markets that expand to developed destinations. The interaction with established agents - companies that have accumulated a great deal of knowledge and technology — enhances the learning possibilities. Thus, developed countries are attractive destinations when a firm is looking for knowledge and fast absorption. 


\subsubsection{Determinants of foreign direct investments and location choices}

There are two distinct phases in the history of FDI from emerging economies: a first flourish of investments in the early 1980s and an acceleration of the process in the late 1990s and early 2000s. Although still recent, these two phases have distinctive features and have been assessed and debated by scholars for some time (Lall, 1983; Wells, 1983; Tolentino, 1993; Dunning and Narula, 1996; Narula, 1996; Dunning and Lundan, 2008).

Studies of the first phase of FDI from emerging countries focused on the specific characteristics of emerging multinationals arising from the peculiarities of the economic development and the industrialisation characteristics of their home countries. These characteristics had an effect on the competitiveness of firms and their innovative efforts. The multinational firms that emerged had success linked to their capacity to attend to the needs of emerging markets and so usually restricted their scope to close and culturally similar locations (Wells, 1983; Tolentino, 1993).

The second phase of emerging investments has as its main feature the increasing speed with which firms are internationalising. They are doing this at earlier stages than did their counterparts in developed countries. The intensification of the globalisation process and the ease of communication across frontiers prompted by new technologies are among the reasons that firms can internationalise faster. There are fewer constraints on mobility, and more and stronger motivations. According to van Agtmael (2007: 35), in an increasingly globalised world, internationalisation becomes less of an option and more of a necessity: "In a world without borders, only global competitiveness is good enough." As already mentioned, numerous firms from the emerging world internationalise to acquire key competitive (especially technological) assets.

Strategic asset-seeking investments had a special importance for lateindustrialising countries in their catching-up process (Dunning et al., 1997; Kim, 1997). The search for strategic assets is one of the main drivers of the internationalisation of firms in general (Dunning, 1993, 1998; Narula, 1996; Li, 2007; UNCTAD, 2005). An outstanding characteristic that currently motivates FDI from emerging economies is the growing importance of asset-seeking FDI for emerging multinationals. They undertake investment earlier than predicted by theories of the growth of the firm and of sequential internationalisation (Tolentino, 1993; Dunning and Narula, 1996; Narula, 1996).

The boom in emerging multinationals operating in developed countries suggests that these firms are seeking assets that are not easily acquired in their home markets. Their international expansion is therefore going beyond the exploitation of competitive advantages originating in the specific reality of emerging markets (Narula, 1996). The recent wave of Chinese investment is in line with the growing role of assetseeking FDI from emerging multinationals in developed countries. The relative disadvantages of Chinese firms are precisely the propellers of FDI, seen as an effective means to equip firms with the competitive strength that they lack (Child and Rodrigues, 2005). 
Another aspect investigated is the modes of entry of emerging multinationals into developed markets. Several studies highlight the role played by mergers and acquisitions (M\&A) in the internationalisation patterns of emerging economies. The total emerging-country M\&A flows climbed from slightly more than USD 40 billion in 1990 to USD 140 billion in 2006 (Economist, 2007). Some of these acquisitions have gained international attention, such as the purchase of the IBM PC line by Chinese Lenovo, of Land Rover by Tata Motors, of RMC by the Mexican cement company Cemex, and of Inco by the Brazilian mining company Vale. Acquisitions and other types of strategic partnerships are an efficient tool to accelerate internationalisation. They provide a fast route to international markets (Mathews, 2002; Mirza and Giroud, 2005) and have been a strategy followed by several emerging multinationals.

The growing importance of asset-seeking investments suggests that developed countries have gained importance as a destination for firms from emerging markets, since more advanced economies have more to offer in terms of technologies, capabilities, and managerial skills (Dunning and Narula, 1996). Makino et al. (2002) tested this relationship for Taiwanese firms and found that their asset-seeking investments tend to be located in developed destinations, provided that the investing firms possessed capabilities that allowed them to compete in such destinations. The conclusion of the study emphasised the importance of accumulated skills and absorptive capacity so that firms can benefit from being in a more advanced location.

In addition to looking for new sources of competitive assets, some internationalising firms from emerging markets have relied on different kinds of innovation, such as new organisational and managerial practices and innovative ways to provide services. This is the case for Brazilian Embraer and Mexican Cemex (Mathews, 2002; van Agtmael, 2007; Goldstein, 2007).

The Brazilian aircraft manufacturer Embraer gained international renown (and a respectable second place in the industry) because of its innovative organisational structure that improved its performance and profitability and the strategic outsourcing of key components to reliable suppliers, thereby achieving competitive costs and reduced risks (Goldstein, 2008). Moreover, Embraer's success relied on its focus on a market niche that was neglected by the top players in the industry, making it the top manufacturer of regional jets (van Agtmael, 2007; Goldstein, 2008).

Similarly, the Mexican cement company Cemex became the leading firm in its sector by building plants in strategic locations, mostly through the acquisition of existing but struggling companies. This allowed it to be as close as possible to clients while also expanding its export range. As a result, the company's businesses are so widespread that no country has more than one third of the total revenue-a clear strategy of "not having all his eggs in one basket" (van Agtmael, 2007).

Both examples above show that the competitive advantages of these firms are based on innovative approaches to internationalisation that rely on organisational and strategy innovation to compete globally (Matthews, 2002).

To summarise, the recent rise of investments from emerging markets' firms suggest an increasing share of asset-seeking investments, especially in developed markets. This does not mean to say that these firms do not have accumulated technologi- 
cal and other strategic assets. In fact, some of these firms have accumulated strong technological capabilities that provided the firm the possibility to internationalise. We deal with this aspect later on. Next, we will describe the background of Brazilian FDI, and then explore the main motivations of these investments.

\subsubsection{Brazilian Multinationals}

This subsection describes how some Brazilian firms are moving forward with their internationalisation process. As mentioned earlier, Brazilian firms started their internationalisation in the early 1980s and at first had an inclination to invest in nearby markets, especially on the American continent (Villela, 1983; UNCTAD, 2006). Apart from geographic proximity, the determinants of the locational choices of Brazilian firms have never been deeply investigated.

Acquisitions by Brazilian firms have also gained momentum in recent years. Brazilian firms have profited from the strength of the Brazilian currency to take over several firms in strategic markets. Among these are: the acquisition of Chaparral Steel and Qanex by Gerdau, Swift by JBS-Friboi, and US Zinc by Votorantim, all in 2007 (FDC, 2008; see Table 2.2 in Chapter 2).

There still lacks a deeper analysis of the determinants of internationalisation of Brazilian firms, similar to what has been done for Chinese and Korean firms, for instance. Studies have engaged into a deep analysis of firms from those countries in order to not only understand the investment determinants but also whether they require a new theoretical approach to FDI in order to be properly understood (Child and Rodrigues, 2005; Mathews, 2006). This is the underlying question that drives us to investigate the determinants of the internationalisation of Brazilian firms, in special to developed countries. Do we observe the same as in studies of Chinese firms? Do Brazilian firms follow their own agenda? How do such motivations fit into extant theories of internationalisation? There is a lot to be studied regarding the internationalisation of Brazilian firms. Whereas some of the biggest companies have been deeply investigated (Petrobrás, Embraer, Vale), many other interesting cases are not yet well known, such as Weg, Sabó, Artecola, Marfrig, Tigre, Localiza, Bematech, and Politec (SOBEET, 2007; Ramsey and Almeida, 2009).

Sabó, for instance, is an auto-parts company that started its internationalisation process in the early 1990s, following its customers. Once established in the foreign market, the company seized the opportunity to establish partnerships with local firms in order to learn and absorb new technologies and better production processes. The company was the only Brazilian firm in that industry to survive the boom of acquisitions by foreign competitors in the late 1990s.

Specific case studies of some well-known Brazilian multinationals have stressed the role of technology in their internationalisation. These include the role of the accumulation of technological capabilities in the successful international expansion of Petrobrás (Carvalho and Goldstein, 2009; Casanova, 2009) and the innovative global business model of Embraer (Goldstein, 2008; Casanova, 2009). However, to the best of our knowledge, no broader study has undertaken to understand the determinants of 
Brazilian investments and how the capabilities of firms relate to the destinations chosen. This is what we propose to do in the remainder of the chapter.

\subsection{Conceptual Framework And Hypotheses}

This section presents the hypotheses to be tested in this chapter. Our starting point is the current debate on the determinants of the internationalisation of firms from emerging countries, which seems to be happening before what had been predicted by existing theories (Dunning et al., 2008). The explanation for that is that they are seeking, through foreign investments into more developed economies, technologies, know-how and other competitive assets that they still lack in their domestic markets. Ownership advantages, in those cases, would play a smaller role than it was the case of the traditional multinationals from developed countries (Dunning et al., 2008).

This search for assets is contemplated in the asset-exploitation determinant for FDI, and therefore constitutes no big news. The big news is that such investments are taking place at much earlier stages than was predicted by traditional approaches. Recent studies have analysed how firms from emerging markets rely on internationalisation to access strategic assets as a means to compete more effectively and so overcome the constraints of their home markets (Makino et al., 2002; Luo and Tung, 2007). The underlying assumption on asset-seeking FDI is that, to assimilate superior technological knowledge, firms choose developed economies as their target locations. In other words, "an emerging-market-based multinational (lacking a technological advantage) could establish a subsidiary in an OECD economy with the objective of gaining access to frontier technologies or seeking exposure to cutting-edge management techniques"(Amann, 2009). The country choice, in this scenario of search for knowledge, would be the one with an advanced technological base that can offer numerous learning and assimilation opportunities (Mathews, 2002; Makino et al., 2002; Lee and Slater, 2007; Goldstein, 2007).

Based on these studies that investigate the existence of asset-seeking investments from emerging markets firms into developed countries, we try to answer whether the same is true to the Brazilian case. Hence:

Hypothesis 1: Brazilian multinationals are more likely to invest in developed destinations when they are motivated by strategic asset-seeking goals.

There is a variety of reasons explaining why firms internationalise with a focus on the host market: to strengthen the relationship with consumers, to prevent the expansion of competitors, to reduce logistics costs, to comply with the firm's growth aspirations, to benefit from investment incentives, to benefit from reduced labor costs (Makino et al., 2002; Dunning and Lundan, 2008). Previous studies suggest that firms from emerging markets tend to invest in more advanced countries due to their higher market potential (Makino et al., 2002). Based on these finding, we expect that Brazilian firms will seek market opportunities in developed countries, where the market size is 
relatively large and consumer purchasing power is higher than in less developed or developing countries:

Hypothesis 2: Brazilian multinationals are more likely to invest in developed countries when they are driven by market-seeking goals.

Emerging markets have long been a natural destination for investments from other emerging economies. The phenomenon, referred to as south-south investment, was especially significant during the first wave of investments of firms from emerging markets and has grown considerably in recent years (Aykut and Goldstein, 2006). Today, south-south FDI still accounts for an important share of the investments of emerging multinationals, and emerging economies tend to be the main investment destinations for emerging firms.

Several studies have stressed the role of less-developed destinations as sources of cheap labour and/or natural resources (Lecraw, 1977; Wells, 1983). Developing countries are important investment destinations for a variety of reasons: for example, they usually have large populations and a market-expansion perspective (the case of China, India and Brazil). On the other hand, less-developed destinations are preferred when firms want to exploit their technological advantages. In general, FDI theories assume that, for internationalisation to take place, firms must possess a certain set of ownership advantages that must be exploited in the host market. Studies of emerging FDI follow the same guidelines, suggesting that the skills possessed by firms from less developed economies are more fit to compete in similarly less developed destinations (Wells, 1983). We therefore raise hypotheses 3 and 4 to verify whether Brazilian investments follow the traditional motivation expected to emerging multinationals:

Hypothesis 3: Brazilian multinationals are more likely to invest in developing countries when their purpose is to gain access to natural resources and low-cost labour.

Hypothesis 4: Brazilian multinationals are more likely to invest in developing countries when their purpose is to exploit their specific technological advantages.

When entering a foreign market, a firm chooses a mode of entry based on its strategy, the resources available, and the existing knowledge of foreign-market operations. Those choices are closely linked to the objectives of the firm, but also reveal the level of commitment that the firm is willing to make. A wise choice certainly influences the final outcome. Entry choices are related to the set of advantages possessed; it is commonly believed that the more assets a firm owns, the more it has to protect, and this leads it to prefer sole ventures. In contrast, firms that lack competitive assets tend to engage in partnerships (Makino and Neupert, 2000).

Likewise, studies on the internationalisation of firms from emerging markets have suggested that firms use acquisitions or associative modes of entry when their destination is a developed country (Mathews, 2002; Barnard, 2008). By acquiring 
assets, the firm incorporates some of the expertise of the acquired business and its employees. Associations with local partners, via joint ventures or mergers, are also used by emerging investors to diminish their uncertainties regarding the new market, hence neutralising some of their liability of foreignness. Acquisitions and partnerships are also good ways to leverage local knowledge and facilitate the learning process (Mathews, 2002). Few studies test the relationship between the determinants of internationalisation and mode of entry for firms from emerging markets, and especially for Brazilian firms.

What Brazilian multinationals have most in common is their great diversity, which does not allow generalisations about the role of wholly owned versus joint international ventures. Since firms from emerging markets have weaker assets when competing in developed destinations, they are expected to prefer joint ventures and other types of firm association over wholly owned subsidiaries. Hypotheses 5 and 6 summarise the assumptions on mode of entry:

Hypothesis 5: Brazilian multinationals are more likely to engage in joint ventures and alliances when investing in developed countries.

Hypothesis 6: Brazilian multinationals are more likely to engage in acquisitions when investing in developed countries.

In summary, engagement in FDI demands a minimum level of competitive assets, and previously accumulated capabilities are required to circumvent the liability of foreignness. These assets are the "O" advantages of Dunning's eclectic paradigm, which take the form of technological capabilities, brands, managerial knowledge, and marketing expertise (Dunning and Lundan, 2008). We expect that firms investing in developed countries rely on a minimal set of capabilities in order to absorb the knowledge available in that location (Makino et al., 2002). We will try to find a relationship between two competitive advantages of Brazilian multinationals and the investment destination. The advantages are: 1) the existence of a skilled labour force at competitive prices (LABORCAP) and 2) the possession of a set of technological, managerial, and organisational advantages, which we label innovative assets (INNOVATION). We expect to find a positive relationship between such capabilities and Brazilian investments in developed destinations:

Hypothesis 7a: Brazilian firms are more likely to invest in developed countries when they possess skilled labour resources.

Hypothesis 7b: Brazilian firms are more likely to invest in developed countries when they possess a set of innovative assets.

Finally, we seek a relationship between firm experience and international expansion to developed countries. It seems reasonable to expect that the commitment to investment is positively related to previous experience, because knowledge is a cumulative and path-dependent process (Nelson and Winter, 1982; Makino et al., 2002). Experi- 
ence also means knowledge about foreign markets and is obtained with time proposes the stages of internationalisation model proposed by the Uppsala School (Johanson and Vahlne, 1977) Experience affects firm performance in three ways: it enhances scale economies, it increases learning and its benefits, and it reduces uncertainty about market operations. After accumulating experience from operations in similar, nearby markets, firms have a greater likelihood of success in developed markets and are therefore more likely to invest in those locations. The following hypothesis seeks to verify how experience influences Brazilian investment in developed countries:

Hypothesis 8: Brazilian firms are more likely to invest in developed countries when they possess previous experience in foreign markets.

To explore how Brazilian multinationals behave in relation to the hypotheses raised in this chapter, the next section will apply a firm-level survey of Brazilian firms and carry out some empirical tests on the sample.

\subsection{Data and Methodology}

The data used in this chapter are from the Global Players survey on the internationalisation of Brazilian firms, carried out by Fundação Dom Cabral in 2007. This is the first time that primary firm-level data has been used to study the general trends in investment for a broad range of Brazilian firms. In particular, this is the first effort to gain a comprehensive understanding of recent outward investment by Brazilian firms, and so the novelty of the information is its major richness. We use this information to understand in depth the recent wave of Brazilian FDI, making this our main contribution to this field.

The survey was submitted to the thousand largest Brazilian firms, measured in terms of total revenue. A small response rate was expected because not many Brazilian firms are engaged in foreign activities, and hence the level of interest in the survey would be low. Of the targeted firms, 93 provided valid responses to the questionnaire. Of these, 73 reported international operations. The data are for fiscal year 2006. The total revenues amount to over 2.4 billion Brazilian Reais (around USD 1.3 billion). The majority of the firms in the sample (92\%) have more than 500 employees. Most operate in foreign markets via export activities, but manufacturing and higher-end activities abroad are also present ${ }^{11}$.

Brazilian multinationals have a wide geographic dispersion. Developed destinations, represented by Europe and North America, account for 37 percent of investment. South and Central America (excluding Brazil) has 23 percent, Africa 10 percent, Asia 13 percent, and Oceania 2.5 percent.

\footnotetext{
${ }^{11}$ For a detailed description of the sample, see Chapter 2.
} 
As described in Chapter 2, productive investments by Brazilian firms (manufacturing and R\&D activities) are concentrated primarily in South American countries, followed by developed countries (the EU and the USA).

\subsubsection{Variables and Models}

This section presents the models that will use survey data to test the hypotheses formulated in this chapter. The variables used were chosen based on the questionnaire. As is common in surveys, the answers capture the perception of the respondent (in this case, usually top management). A Likert scale was applied to measure the agreement level; a scale of six was used to avoid central-tendency bias. We built dummy variables for the following aspects: 1) the main motivation driving the firm to internationalisation; 2) the positioning of the firm in terms of competitive advantages vis-àvis foreign competitors; 4) the location of foreign investment and the type of activity carried out.

The dependent variable is the investment location: developed destinations take the value 1 and less-developed destinations 0 . Firms were asked about the location of their foreign activities in terms of eight regions: North America, the European Union, Eastern Europe and Russia, the Middle East, South and Central America, Asia, Africa, and Oceania. North America and the European Union are considered to be developed destinations.

As independent variables we use two sets of variables: motivation and capabilityrelated. We create five sets of investment motivations, based on the responses to each investment determinant; dummies are created and take the value 1 when firms report an above average-answer for the variable in question. The motivation variables are: strategic-asset-seeking (TECSEEK), market-seeking (MKTSEEK), technologyexploiting (TECHEX), and resource-seeking (RESEEK). Using information on the perceived competitive strengths of the firm vis-à-vis their international competitors, we also defined three variables related to firms' advantages. We used the same approach of above-average responses. The first is the presence of skilled human resources (LABORCAP). The second is the reliance on innovation, the use of new technologies, the use of modern equipment, and responsiveness to the demands of international customer, which we label innovative advantages (INNOVATION). The third is the number of years that the company has been established overseas (EXPERIENCE); we use the logs of these responses. A control variable, firm size is defined as the log of the number of employees (LNEMPLOY).

To test the hypotheses formulated in this chapter, we run four logit models that relate investment determinants and firm competitive advantages to the investment destination. The models capture the influence of the motivation and firm capabilities on the probability of a firm choosing a developed country as and investment destination. In each of the models we added control variables for the technological intensity of the sectors involved: low-tech in model 1, mid-low-tech in model 2, mid-high-tech in model 3, and high-tech in model 4. Model 5 tests how different modes of entry impact on the probability of choosing a developed destination. The correlation matrix is 
used to check the collinearity between variables (see Correaltion Table in Appendix A).

\subsection{Results}

The results of the analyses are presented in Tables 3.2 and 3.3; Table 3.1 brings the correlation matrix. One striking result is that to the firms of the sample, the search for technological assets are not the drivers of investments to developed destinations, as proposed and verified in several recent studies about emerging multinationals (Matthews, 2004; Child and Rodrigues, 2005). Instead, technology-exploiting was the key determinant for the investments of Brazilian firms in developed economies. This result leads us to reject hypothesis 1 .

Hypotheses 3 and 4 were based on the assumption that Brazilian multinationals would chose developing countries when their purpose was to gain access to natural resources or cheap labour (H3) or to exploit their technological advantages. If so, we would expect a negative signal to the coefficients related to the variables RESEEK and TECHEX; in this sense, the results were unexpected: TECHEX had a positive and significant sign, which means that, contrary to our assumption, Brazilian multinationals invest in developed countries with the purpose of exploiting their existing technological advantages. The coefficient related to the variable RESEEK presented the expected negative value but with no statistical significance.

Hypothesis 2 referred to an investment determinant that we had no certain assumption about where it would locate. The results were negative, suggesting that Brazilian multinationals would choose developing destinations when aiming to expand their market. Results, however, were non significant, and for that reason hypothesis 2 was not accepted and no clear conclusions can be drawn about market-seeking investments. One possible explanation for this is that the market-seeking investments from Brazilian firms are important in both locations, developed and developing countries.

In relation to the capabilities linked to internationalisation into developed markets, the results obtained allowed us to accept hypothesis 7a: the variable related to skilled labour presented the expected positive signal and was statistically significant. The variable related to innovation, however, had a negative signal, but with no statistical significance. Hypothesis $7 \mathrm{~b}$ was therefore not accepted. 
Table 3.1 - variables used in the models

\begin{tabular}{ll}
\hline Variable & \\
\hline Location & Dummy variable that assumes 1 for FDI located in developed countries; value 0 otherwise \\
Tecseek & Dummy variable that assumes 1 for technology-seeking motivation to internationalise \\
Techex & Dummy $=1$ for technology exploiting motivations \\
Reseek & Dummy $=1$ for resource seeking motivations \\
Mktseek & Dummy $=1$ for market-seeking motivations \\
efiseek & Dummy $=1$ for efficiency-seeking motivations \\
laborcap & Dummy that takes value =1 for skilled human resources as a competitive advantage of the firm \\
innovation & Dummy that takes value=1 for innovation \& technological capabilities as a competitive advantage \\
experience & Number of years that the company has been established overseas \\
lnemploy & Log of the number of employees, used as a proxy for firm size \\
low tech & control variable that takes vaule 1 if sector is low-tech \\
medium-low & control variable that takes vaule 1 if sector is mid-low tech \\
medium-high & control variable that takes vaule 1 if sector is mid-high tech \\
high-tech & control variable that takes vaule 1 if sector is high tech \\
\hline
\end{tabular}




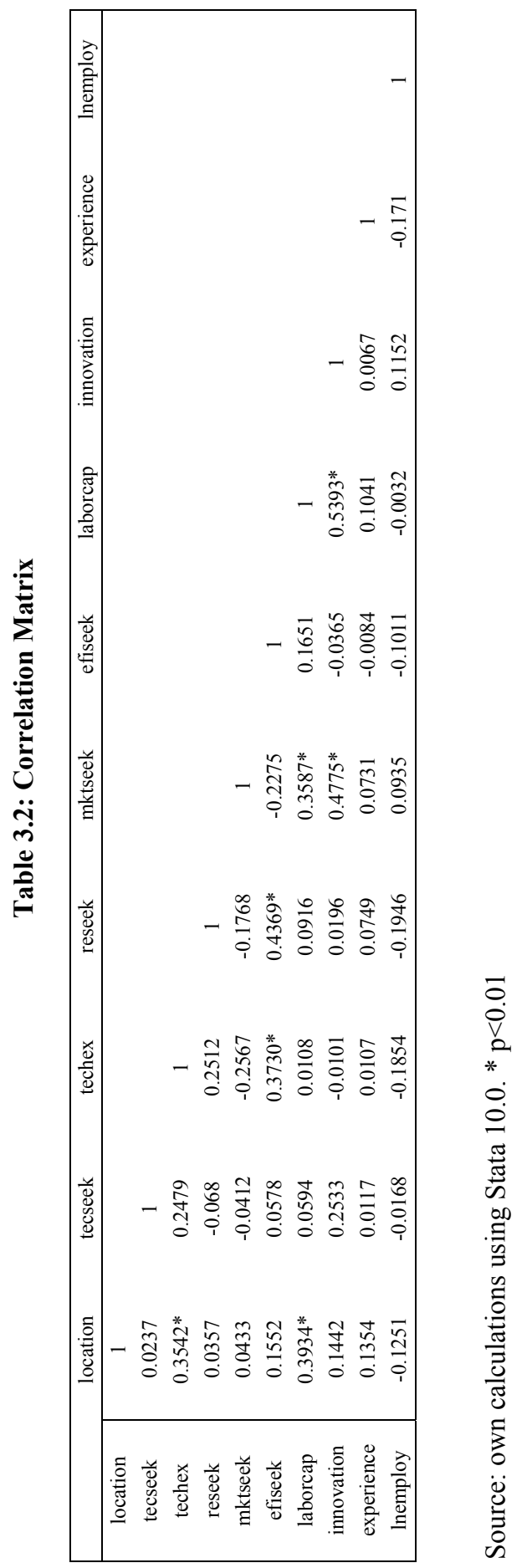


Table 3.3: Results of logistic regression

\begin{tabular}{|c|c|c|c|c|}
\hline \multicolumn{5}{|c|}{ Dependent Variable: LOCATION $(\mathrm{DC}=1 ; \mathrm{LDC}=0)$} \\
\hline VARIABLES & Model 1 & Model 2 & Model 3 & Model 4 \\
\hline Tecseek & $\begin{array}{l}-0.654 \\
(1.191)\end{array}$ & $\begin{array}{l}-0.599 \\
(1.223)\end{array}$ & $\begin{array}{l}-0.373 \\
(1.249)\end{array}$ & $\begin{array}{l}-0.525 \\
(1.178)\end{array}$ \\
\hline Techex & $\begin{array}{l}2.050 * * \\
(0.930)\end{array}$ & $\begin{array}{l}1.755^{* *} \\
(0.873)\end{array}$ & $\begin{array}{l}2.169 * * \\
(0.894)\end{array}$ & $\begin{array}{l}1.822 * * \\
(0.861)\end{array}$ \\
\hline Reseek & $\begin{array}{l}-1.656 \\
(1.579)\end{array}$ & $\begin{array}{l}-1.524 \\
(1.598)\end{array}$ & $\begin{array}{l}-1.282 \\
(1.678)\end{array}$ & $\begin{array}{l}-1.905 \\
(1.541)\end{array}$ \\
\hline Mktseek & $\begin{array}{l}-0.361 \\
(0.877)\end{array}$ & $\begin{array}{l}-0.362 \\
(0.870)\end{array}$ & $\begin{array}{l}-0.174 \\
(0.875)\end{array}$ & $\begin{array}{l}-0.482 \\
(0.907)\end{array}$ \\
\hline Laborcap & $\begin{array}{l}1.906^{* * *} \\
(0.739)\end{array}$ & $\begin{array}{l}1.868^{* *} \\
(0.734)\end{array}$ & $\begin{array}{l}2.399 * * * \\
(0.824)\end{array}$ & $\begin{array}{l}1.855^{* *} \\
(0.735)\end{array}$ \\
\hline Innovation & $\begin{array}{l}-0.243 \\
(0.770)\end{array}$ & $\begin{array}{l}-0.117 \\
(0.755)\end{array}$ & $\begin{array}{l}-0.554 \\
(0.840)\end{array}$ & $\begin{array}{l}-0.0863 \\
(0.760)\end{array}$ \\
\hline Foreign experience & $\begin{array}{l}0.475 \\
(0.441)\end{array}$ & $\begin{array}{l}0.371 \\
(0.440)\end{array}$ & $\begin{array}{l}0.127 \\
(0.453)\end{array}$ & $\begin{array}{l}0.347 \\
(0.419)\end{array}$ \\
\hline Size (Lnemploy) & $\begin{array}{l}-0.00736 \\
(0.145)\end{array}$ & $\begin{array}{l}-0.0445 \\
(0.139)\end{array}$ & $\begin{array}{l}0.00123 \\
(0.148)\end{array}$ & $\begin{array}{c}-0.0333 \\
(0.141)\end{array}$ \\
\hline Low tech & $\begin{array}{l}-0.671 \\
(0.715)\end{array}$ & & & \\
\hline Medium-low & & $\begin{array}{l}0.178 \\
(0.961)\end{array}$ & & \\
\hline High-tech & & & & $\begin{array}{l}1.603 \\
-1.917\end{array}$ \\
\hline Constant & $\begin{array}{l}-2.001 \\
-1.423\end{array}$ & $\begin{array}{l}-1.959 \\
-1.518\end{array}$ & $\begin{array}{l}-1.896 \\
-1.529\end{array}$ & $\begin{array}{l}-1.933 \\
-1.419\end{array}$ \\
\hline $\mathrm{N}$ & 61 & 61 & 56 & 61 \\
\hline Prob $>$ Chi2 & 0.0457 & 0.0597 & 0.0112 & 0.0466 \\
\hline Pseudo Chi2 & 0.220 & 0.2117 & 0.2754 & 0.2213 \\
\hline Standard errors in $\mathrm{p}$ & $\operatorname{ses}: * * * \mathrm{p}$ & $\mathrm{p}<0.05, *$ & & \\
\hline
\end{tabular}

Experience in international markets presented the expected positive sign, suggesting that firms already established overseas for some time would be more likely to invest in developed countries. However, results were not significant, so we cannot accept hypothesis 8 . Firm size presented a surprising negative sign but values were non significant; the same was valid for the sectoral control variables, which presented no statistical significance in the models.

The results obtained in model 5 suggested that acquisitions are an important entry mode into developed markets, which was in line with the expected, leading us to accept hypothesis 6 . Joint ventures and alliances, on the other hand, did not prove to be a mode of entry related to investments of Brazilian firms in developed markets, which leads us to reject hypothesis 5. Surprisingly, Greenfield investments showed a posi- 
tive and significant result and are a mode of entry that is related to developed destinations.

We interpret this as follows: Brazilian investors prefer sole ventures when investing in developed markets. Acquisitions would be a preferred mode of entry because it enables the best of both worlds: firms can access knowledge about the market, the country and its consumers by purchasing a firm that it will own entirely, still keeping decision power in its hands.

Table 3.4: Results from model 5

\begin{tabular}{ll}
\hline & \\
& \\
Dependent Variable: LOCATION $(\mathrm{DC}=1 ; \mathrm{LDC}=0)$ \\
VARIABLES & Model 5 \\
\hline Acquisition & $\mathbf{3 . 1 2 4 * * *}$ \\
& $(0.975)$ \\
JV & 0.708 \\
& $(1.045)$ \\
Franchising & -1.812 \\
& $(2.144)$ \\
Licensing & -1.652 \\
& $(1.292)$ \\
Greenfield & $\mathbf{1 . 6 9 5 *}$ \\
& $(0.924)$ \\
Alliance & 0.0443 \\
& $(0.887)$ \\
Merger & 0.122 \\
& $(2.384)$ \\
Constant & $-1.559^{*}$ \\
N & $(0.922)$ \\
Prob $>$ Chi2 & 53 \\
Pseudo Chi2 & 0.0209 \\
Standard errors in parentheses & \\
\hline$* * * \mathrm{p}<0.01, * * \mathrm{p}<0.05, * \mathrm{p}<0.1$ & \\
&
\end{tabular}

\subsection{Discussion}

This chapter examined the impact of capabilities and motivations on the location choice of foreign investments made by Brazilian firms. The proposed hypotheses were based on evidence found in recent studies that suggest that firms from emerging markets are investing in more developed destinations with the purpose of gaining access to strategic assets.

That proved not to be the case of Brazilian multinationals. Contrary to what may constitute a new wave of investments from emerging markets, Brazilian firms do not invest in developed countries with asset-seeking motivations. The findings of this chapter suggest a positive and significant result for technology-exploiting investments of Brazilian firms in developed countries. The result indicates that Brazilian firms in 
the Global Players sample tend to rely on their existing specific capabilities to establish their businesses abroad, including developed destinations.

Another evidence found in the chapter may sound as a contradiction to the general assumptions on emerging multinationals. Recent studies usually argue that acquisitions are an entry mode into more developed economies because it would grant the investing firm a quick access to knowledge, know-how and market experience that was indigenous to the acquired firm. However, we found that investments from Brazilian firms to developed countries are mostly technology-exploiting rather than technology seeking. An explanation for that lies in the fact that most acquisitions made by Brazilian multinationals in developed countries are in sectors such as mining, food and quarrying, and therefore much probably have a market seeking rather than a technology seeking purpose.

This is important information for the discussion of emerging, and in particular Brazilian, multinationals. Brazilian firms have an investment pattern that relies on their existing competitive assets. This corroborates the assumption made in an earlier chapter of this thesis that the industrialisation process and the choice of specific sectors as key drivers of economic growth was central to the establishment of the national winners that would later become the major Brazilian multinationals. It does not seem far from reality to suppose that a great share of the firms that constitute the Global Players sample are from resource-rich, labor-intensive industries that are, indeed, entering developed markets with an intent to conquer more resource access through acquisitions of local firms. A quick look at the largest multinationals from Brazil listed on the Top 100 non-financial multinationals from developing and transition economies for 2010 corroborates this: Vale, Petrobrás and Gerdau are the only Brazilian multinationals to appear on the list, all strongly relying on natural resources as their core business (UNCTAD, 2012). These firms have adopted a strong strategy of acquiring assets in developed markets in order to own reserves of raw material that are essential to their business (CEPAL, 2011; FDC, 2012).

The results also corroborate early premises on the technological capabilities of firms from emerging markets but show that Brazilian firms have moved a step beyond that of operating profitably in similar markets. Brazilian firms have capabilities that were developed in accordance with the specific conditions of resources, capital, and demand. These are important competitive assets, but firms have also developed their advantages by building up technological, managerial, and marketing capabilities, enabling their expansion into countries that do not replicate the conditions of their home market (Lall, 1983).

The concentration of Brazilian multinationals on traditional sectors does not mean that such firms lack technological capabilities. Brazilian firms have technological capabilities that allow them to compete in the world market in industries such as in oil and gas, pulp and paper, auto-parts, and aircraft (Lall, 1983; Tolentino, 2000). Firms in these sectors have developed a successful trajectory towards foreign markets. The multinationals of today are the companies that had the strength to grow and compete in the past. The role of technological capabilities for the internationalisation of 
firms in higher-level markets is also evidenced by the case of Petrobrás, which will be further explored in the thesis.

The empirical findings also pinpointed the role of skilled labour as a competitive asset for the internationalisation of Brazilian firms. Innovation did not stand out as a direct advantage, but Brazilian investors identified the skills embedded in their human resources as an important competitive asset. This means that the knowledge assets from Brazilian firms are "built upon their own efforts, experience and skills" (Lall, 1992: 166) and that these firms believe their richer assets are intangible and rooted in their personnel.

Brazilian firms are in a period of intensive expansion into foreign markets, with huge acquisitions in developed markets ${ }^{12}$. Brazilian investors have a preference for Greenfield investments or sole ownership over partnerships with local firms, which is in line with the preference of multinationals in general for sole ventures (Dunning and Lundan, 2008). As acquisitions gain importance as a mode of entry into foreign markets, we acknowledge the effort of Brazilian firms to gain access to these markets at a faster pace. Such acquisitions are part of a strategic plan to establish overseas at a faster pace but is also result of the economic turmoil inflicted on most developed nations, which, along with the valuation of the Brazilian currency makes acquisitions of foreign firms a specially good deal to Brazilian investors.

Despite its small size, our sample is relatively significant given the limited number of Brazilian firms that have direct (and productive) investments overseas. Nevertheless, the sample size has posed some challenges in the econometric tests and complicates further analyses or generalisations.

It is possible to say that the Brazilian firms analysed in this chapter presented a somewhat different pattern from that followed by investing firms from East Asian countries. The latter have, to a large extent, targeted developed markets in order to access technologies or purchase brands (Narula and Dunning, 2000; Makino et al., 2002; Matthews, 2002; Child and Rodrigues, 2005). There may be firms in Brazil that are expanding to increase their technological capabilities, but this does not seem to be the main driving force in Brazilian internationalisation.

Brazilian firms have specific characteristics that differ from those seen in the foreign investments from traditional multinationals. Indeed, it is hard to consider even the group of emerging countries as homogeneous. While comparative analyses can indicate best practices and suggest successful policies for fostering foreign investments, only in-depth studies can reveal each country's idiosyncrasies. That does not mean to say that one cannot understand or analyse foreign investments from a country like Brazil with the frameworks, theories and paradigms that have been developed so far. The eclectic paradigm can still provide much of the explanation necessary to understand how ownership assets (no matter how specific the assets of a certain firm located in an equally specific country are) are still the kick-start of the internationalisation process.

${ }^{12}$ For a list of recent acquisitions of foreign firms, see the previous chapter, Table 1, and CEPAL $(2008 ; 2011)$ and Almeida (2009). 
At the same time, the framework provided by the earlier works on FDI by developing countries (Lall, 1983; Wells, 1983) still contributes with their vision that technology can be quite specific to a developing country context. The news to be added to this framework is that the specificity of technological capabilities of emerging multinationals seem to fit also in more developed destinations. The success of Vale, Gerdau, Petrobrás, for instance, are a living proof of this fitness. Moreover, specific technological capabilities of firms from emerging or developing countries do not mean late or mature technologies as believed earlier. Their technological development are at the state of the art in their fields, most of times, and have proved to work in countries with distinct levels of economic development.

The limitations of the findings arise from the survey database, which may not be fully representative of the population of enterprises. We tried to overcome these limitations by adding knowledge from individual case studies, available from other data sources. These other sources indicate that the findings of the Global Players survey are fairly representative of the population of Brazilian firms. However, further attempts to understand the specific variables of our models would contribute to knowledge in this area.

An interesting investigation for future research would be to assess the impact that more technologically intensive investments, particularly those driven by the pursuit of technological assets, would have on the domestic economy. Studies of absorptive capacities and technological spillovers suggest that there is much to gain from this type of foreign incursion. Many aspects of Brazilian FDI deserve further attention. The dissemination of information on this subject could be of great value to future investments and to government initiatives for internationalisation. 


\section{CHAPTER 4 - LEVELS OF INTERNATIONALISATION AND FIRM Advantages: FDI Theory ApPlied To Brazilian Multinationals}

\subsection{Introduction}

Until recently, the literature on the internationalisation of Brazilian firms focused mostly on international expansion through exports (Iglesias and Veiga, 2004; Rocha, 2002; Arbix et al., 2005). Exports have long been the main international activity carried out by Brazilian firms, and the country's current accounts balance is a major issue for policymakers. Nevertheless, as the previous chapters have highlighted, some firms are expanding their internationalisation and increasing their commitment to foreign markets. This is shown by the growing number of overseas acquisitions and Greenfield investments in production plants by Brazilian firms.

The purpose of this chapter is to understand how Brazilian firms evolve from exporting towards more committed activities in foreign markets. To understand this process, we start from two important theories of international business studies: the eclectic paradigm of ownership, location, and internalisation (OLI) advantages, and the Uppsala internationalisation process model. Using this empirical background we investigate how certain competitive advantages relate to different levels of commitment of investments from Brazilian firms.

At first glance, the internationalisation of Brazilian firms seems to follow a gradual evolution, as proposed by the Uppsala theory. Activities are concentrated on exports and gradually evolve towards a network of export-supporting activities (post sales, sales representatives, marketing offices). Some firms make a deeper commitment and undertake production or R\&D activities abroad (see Chapter 2, Fig. 2). However, different sectors internationalise at different speeds. Commitment levels are expected to differ depending on sector, firm competence, and specific choice of international strategies. Recent studies have observed that multinationals from emerging economies are increasing their presence worldwide much faster than did the traditional multinationals from developed countries, which brings into question the assumption that internationalisation takes place in gradual stages (Freeman et al., 2010).

To better understand the internationalisation movements of Brazilian firms in the light of internationalisation theories, this chapter revisits the OLI paradigm and the Uppsala theory of international investments. The two approaches were chosen because of their framework in which competitive (or ownership) assets of firms are a central determinant of foreign activities. The previous chapter of this thesis investigated the main competitive advantages of Brazilian firms, and revealed that some Brazilian investors rely on their specific technological capabilities to invest abroad, rather than seeking technological assets overseas, even when investing in developed destinations. In this chapter we investigate whether the existence of certain ownership 
advantages increases the probability of the firm to engage in deeper levels of commitment of activities abroad.

The remainder of this chapter is divided into six sections. Section 2 sets up the conceptual background of firms' asset ownership and the gradual stages of internationalisation, emphasizing the characteristics of each theory that are central to our analysis. Section 4.3 presents the main hypotheses derived from this background that will be tested in the chapter. Section 4.4 discusses the internationalisation process of Brazilian multinationals, its characteristics, and changes in investment over the past twenty-five years. Section 4.5 presents the data and the empirical application; Section 4.6 presents the results of the regressions. A final section discusses the chapter's main findings.

\subsection{Theories of the International Expansion of Firms: Asset Accumulation and Internationalisation Stages}

Our analysis is based on two theories of international investment that view knowledge as a key asset for international expansion. We now briefly present these two theories: the first derived from an economic approach to internationalisation and the second from a behavioural approach.

\subsubsection{Eclectic Paradigm}

The eclectic paradigm of FDI, proposed by John Dunning, states that a firm should accumulate a certain amount of tangible and intangible assets - their competitive advantages - in order to evolve into a multinational corporation. The decisions of firms to establish (and produce) in certain locations is linked to the possibility to exploit such advantages in the relevant markets. Innovative capabilities and technological advantages are important ownership assets, and play a central role in the global competitiveness of firms. In other words, ownership assets are determinants of internationalisation (the O in the OLI paradigm) (Dunning and Lundan, 2008). Dunning later revisited the OLI paradigm, adding a macro-dynamic component to the evolution of O-assets, as countries reach further stages of development (Dunning, 1988). The increasingly globalised economy, with firms interacting and exchanging information more than ever before, brought a new feature into the eclectic paradigm: firms can access assets from other economic actors through cooperation and networks (Dunning, 2001a).

The relationship between the ownership of key competitive assets such as technology and successful international expansion has been thoroughly assessed and corroborated by various studies. A study based on the Brazilian innovation survey, PINTEC, showed that, in general terms, Brazilian firms with foreign investments are more innovative than those who do not have FDI. This indicates that innovation is an important asset in the international competitiveness of Brazilian firms, and also suggests that the pressure of foreign competition stimulates innovative behaviour (Arbix 
et al., 2005). Chapter 3 in this thesis showed that the strongest knowledge assets of Brazilian firms are embedded in their human resources and managerial expertise. The chapter also revealed that even investments that target developed countries seem to rely on the exploitation of technological assets already accumulated by the firms. This contrasts with the recent flows of investments from other emerging countries such as China, which have targeted developed destinations with the clear goal of accessing assets and capabilities lacking in domestic markets (Mathews, 2002; Child and Rodrigues, 2010).

In resume, our findings suggest that Brazilian firms are internationalising their activities based on the exploitation rather than on the search for assets, and that such exploitation is based on a set of $\mathrm{O}$-assets that are specific to these firms.

\subsubsection{Uppsala Internationalisation Model}

Another interesting approach to internationalisation originates from the Nordic business school. The central aspect of the Uppsala internationalisation process model is that firms usually internationalise through gradual stages of commitment to the foreign market. The reason is that, in their early years, firms lack the necessary knowledge and information about the market, hence incurring higher investment risks. As they accumulate experience, they gain the tools to perform better, and can therefore afford a more significant presence abroad. The geographic range of investments is also expected to widen, as, with experience, psychic distance ${ }^{13}$ becomes less of a deterrent in internationalisation plans.

The Uppsala internationalisation theory focuses on how firms accumulate the necessary learning for more successful internationalisation. Further developments to the theory considered other forms of knowledge accumulation such as learning through imitation, through the incorporation of people or other organisations, and through networking (Forsgren, 2001; Johanson and Vahlne, 2009). Acquisitions of foreign firms are particularly effective at increasing the learning pace and sometimes occur despite the lack of market information rather than as a consequence (Forsgren, 2001; see discussion in previous chapters). In this regard, these more recent developments can better explain the internationalisation movements from emerging countries.

Whereas the theory is by no means generalisable, it provides a good explanation for some cases, besides its obvious application to Swedish firms. In studies on the internationalisation of Brazilian firms, the Uppsala model has been applied to explain the evolution of firms from different sectors and have proved to fit reasonably well (Hilal and Hemais, 2003; Rosa and Rhoden, 2007; Carneiro et al., 2008; Turolla and Margarido, 2008).

Questions about the applicability of a model of gradual internationalisation arise because of the emergence of born-global firms. This has reopened the debate and the

\footnotetext{
13 Psychic distance according to the Uppsala school is "the sum of factors preventing the flow of information from and to the market. Examples are distances in languages, education, business practices, culture and industrial development" (Johanson and Vahlne, 1977: 24)
} 
search for new approaches to internationalisation (Freeman et al., 2010). These global enterprises are born in a new context of globalisation, where distances have shrunk because of the technological revolution in communication, and competition taking place beyond domestic borders ${ }^{14}$. They are however a specific case and their existence does not, in our view, contradict internationalisation theories that have explained a considerable number of cases.

The Uppsala model resembles the eclectic theory of internationalisation in the common emphasis given to learning and experience as factors in the competitive advantages of firms. This is the background against which we set up this chapter's discussion of Brazilian multinationals. Knowledge is a central competitive asset, and foreign investments evolve towards stages of greater commitment according to the possession of such assets. Both the eclectic paradigm and the Uppsala model make assumptions that are observed in the characteristics of Brazilian FDI. The pace of firms' commitment to foreign markets is not constant across all firms and sectors. For Brazilian firms, it is especially important to understand the characteristics and advantages/assets that are related to internationalisation, and this is what we propose to do in this chapter.

Most Brazilian firms resume their internationalisation to exports activities, and this makes crucial to distinguish a non-internationalised firm from an exporter, and an exporting firm from a Brazilian multinational that undertakes value-adding activities in foreign markets. Understanding the reasoning behind higher commitment levels in foreign markets is of great value for research purposes and also for government policies that aim to stimulate internationalisation.

The specific assets that explain foreign investments seem to vary between traditional multinationals and emerging multinationals, and amongst the latter. We therefore expect to contribute to the debate by establishing a relationship between the assets of firms and their internationalisation levels. We look to the characteristics of the internationalisation process featured by the OLI and Uppsala approaches - asset accumulation and experience - to understand how they help to explain recent patterns of Brazilian investment.

In the next section we develop our central hypotheses on the international operations of Brazilian firms, by associating competitive assets with different levels of internationalisation. We expect to shed light on how different degrees of international commitment relate to firms' competitive advantages. We also want to discover whether experience in foreign markets has an impact on the commitment of firms with foreign investments.

\footnotetext{
14 The born global concept is sometimes applied to firms with more than 10 percent of production destined to exports. The term is interpreted differently by different authors (Bals et al., 2008).
} 


\subsection{Hypotheses}

We formulate the with the purpose of assessing how internationalisation levels relate to the accumulation of market knowledge and competitive advantages. According to Uppsala (Johanson and Vahlne, 1977, 2009), levels of internationalisation imply a gradual, increasing commitment of firms to foreign markets through more complex activities over time. The first level of internationalisation is export activities; later firms move to higher levels of commitment via overseas activities that demand higher and less volatile investment levels. In this chapter, we establish three different levels of internationalisation (DOI), based on the assumptions of the Uppsala model:

0 : no international operation

1: exports to foreign markets

2: exports and value-adding activities abroad (marketing, post sales, procurement, production, and R\&D), all labelled here as FDI.

We choose to consider other types of activity, such as marketing and sales departments abroad, at the same level as production activities because, for many sectors, such investments indicate as deep a commitment as possible. There are several Brazilian firms for which production activities are not in the internationalisation agenda, which nonetheless have a desire to establish their brands internationally and to increase their presence overseas. This is true for the cosmetics sector and also the pulp and paper industry. In both cases, the firms have a strong technological base and environmentally sustainable production practices as a central competitive tool, plus competitive production prices domestically, which indicates that only export expansion makes sense (Valor Econômico, 2010). Sales and distribution offices, concept stores, and marketing operations abroad are the mechanisms used by these firms to reinforce their presence beyond product dissemination (Araújo and Serpa-Blundi, 2005; Rocha, 2003; van Agtmael, 2007).

With this in mind, we investigate how the possession of certain assets influences firms' internationalisation level. We pay special attention to technological capabilities, skilled labour, managerial capabilities, and brand advantage. These can be regarded as the ownership (O) advantages of firms that are the backbone of the eclectic paradigm (Dunning and Lundan, 2008). There are other competitive advantages such as access to natural resources and the ability to operate in challenging market conditions, which are usually related to firms from emerging markets.

According to the OLI paradigm and the Uppsala internationalisation model, it is reasonable to expect a deeper commitment to a foreign market to be related to a more complex set of competitive advantages (Johanson and Vahlne, 1977; Dunning and Lundan, 2008). The reason is that the accumulation of knowledge is crucial to the economic development process (Penrose, 1959). Knowledge, especially in the form of technological assets, is a strong competitive advantage of firms operating in foreign markets. Skilled human resources are a central competitive asset, especially because 
many of the technological capabilities of firms are embedded in their personnel. Penrose emphasises that the capabilities of men depend to some extent on the resources at their disposal (Penrose, 1959). It is therefore worth reinforcing some aspects discussed in earlier chapters: that the industrial capabilities created at early stages of industrialisation have enabled the development of firms in some sectors and not others.

On the other hand, some cases of late internationalising companies, especially from China, seem to contradict the assumptions of traditional FDI theories (Child and Rodrigues, 2010). In these cases, FDI is usually related to seeking rather than to exploiting existing advantages. The example of Haier, the appliance manufacturer, reveals that the firm chose a bold expansion based on the philosophy of its CEO: "first, take over a difficult developed market, then go to developing markets" (Child and Rodrigues, 2010: 47). The internationalisation of many Chinese firms follows this different rationale, involving fast expansion to catch up technologically rather than the gradual approach of the Uppsala model.

Brazilian firms, as shown by several case studies and by evidence collected in this thesis, seem to follow a gradual approach in both their commitment levels and in the distances of their investments. We are therefore again testing the validity of existing models vis-à-vis the need to revisit them in order to understand emerging FDI, and in particular foreign investments of Brazilian firms.

Starting from the assumption that Brazilian firms gradually increase their commitment to foreign markets as they accumulate capabilities and skills, we test the following hypotheses:

H1: The presence of Technological assets as a competitive advantage increases the probability of firms engaging into deeper internationalisation levels.

H2: The presence of skilled labour as a competitive advantage increases the probability of firms engaging into deeper internationalisation levels.

Similarly, brand advantages can be the result of accumulated technological efforts, or of a reputation developed over years of operation in a certain market and industry. Brand reputation also depends on the code of conduct, norms and corporate culture, social responsibility, and other formal and informal value-adding processes (Dunning and Lundan, 2008). Firms with a strong brand reputation have an additional asset to compete in foreign markets. This leads to the following hypothesis:

H3: The presence of Brand as a competitive advantage increases the probability of firms engaging into deeper internationalisation levels.

Organisational innovation is also an important aspect of success and in this regard managerial capabilities play a strong role. This is the case for Embraer, the Brazilian aircraft manufacturer that has a successful international presence because of its ability to innovate by entering new market niches, and by managing the production of several components to outside suppliers all over the world (Casanova, 2009; Bedaque Jr et al., 2010). The ability to innovate in areas other than technology is especially relevant for 
emerging-market companies. An evidence of this is the fact that much (or most of) of the innovative effort of Brazilian MNCs depends on sources of knowledge that go beyond R\&D activity (IBGE, 2007). From this we develop the following hypothesis:

H4: Managerial capabilities as a competitive advantage increases the probability of firms engaging into deeper internationalisation levels.

The access to natural resources may have a special appeal to Brazilian firms in resource-rich sectors, since many multinationals from the country are in naturalresource industries (Vale, Petrobrás, and Gerdau are some examples). However, the importance of resources for internationalisation is not straightforward. Natural resources, being abundant in the home country, might be an important advantage for firms engaging in export activities. On the other hand, firms may need to secure access to more resources, or resources not available in the home market (such as zinc, the motivation for Vale to acquire businesses in the USA). The sectoral concentration of emerging multinationals has changed over the years, with the service sectors gaining ground (UNCTAD, 2006; Dunning et al., 2008). To check the importance for Brazilian investment of access to natural resources, we test whether advantages originating from such access lead to further levels of internationalisation, therefore influencing the entry of Brazilian firms into foreign markets, especially via exports.

H5: Access to natural resources, as a competitive advantage of firms, increases the probability of firms engaging into deeper internationalisation levels.

The size of the firm is usually considered a positive factor in internationalisation, because it is a costly process that demands scale advantages. Multinational corporations are, in theory, expected to be large. This is why a few multinationals dominate production efforts, assets, and sales worldwide. According to Dunning and Lundan (2008), the top 500 multinationals account for 75 percent of total foreign production and the top 50 account for 35 percent. It is therefore expected that larger firms internationalise more; factors that determine the growth of the firm may also influence foreign expansion. The reasonable expectation is that a larger presence in foreign markets is linked to higher levels of internationalisation, but this might not be true for all sectors. Size is therefore a control variable in our model.

It also seems reasonable to expect that foreign experience contributes to a deeper commitment to foreign markets. Experience, measured by time, is a valuable way to accumulate knowledge and capabilities and, therefore, reduce risks related to the liability of foreignness (Forsgren, 2001; Johanson and Vahlne, 1977, 2009). Six out of seven of the largest multinationals in the world are at least fifty years old ${ }^{15}$ (UNCTAD, 2006); this is another indicator that experience (together with capital accumulation and scale) leads to successful international expansion. We choose to treat

15 GE, Ford, GM, BP, Exxon Mobil, and Royal Dutch Shell were all established in the early $20^{\text {th }}$ century. The exception is Vodafone, established in 1980 (UNCTAD, 2006). 
foreign experience as a valuable asset for international competitiveness, because it relates to the accumulation of knowledge in new markets, a characteristic that may have a positive effect on the level of internationalisation.

H6: Foreign experience is a competitive advantage of firms and therefore increases their probability of engaging into deeper internationalisation levels.

The next section will take a closer look at the internationalisation of Brazilian firms. Specific case studies of Brazilian firms can provide initial hints about how investors take internationalisation steps. The analysis of a firm-level survey will then clarify how competitive assets relate to different internationalisation levels.

\subsection{Internationalisation Process of Brazilian Multinationals}

Early studies carried out in the 1980s described the first FDI steps of Brazilian firms. Villela (1983) outlined the investors, the main destinations, and the main sectors. The author listed twenty firms as "practically the entirety of Brazilian Multinationals" (Villela, 1983: 221). These early Brazilian investments were usually directed to culturally and economically similar countries, mostly in Latin America (including Mexico) and Africa. Developed destinations were mostly the USA, Portugal, and other western European countries. The main sectors were banking, construction and engineering, and oil exploration and production, with a few manufacturing investments (Villela, 1983; Tolentino, 2000).

Given the cautious start of Brazilian investments abroad, favouring locations with cultural and economic similarity (a short psychic distance), it is reasonable to associate the internationalisation of Brazilian firms with the gradual process proposed by the Uppsala model. More recent Brazilian investments also indicate a gradual but increasing involvement as firms accumulate capabilities and expertise.

Most firms from the sample analysed in this thesis are still at the first level of commitment to international activities. One third of the firms undertake activities that involve more complexity and a stronger resource commitment. The previous chapters of this thesis have provided a picture of the preferred markets for the international operations of Brazilian firms: South and Central America, which are the closest markets geographically and psychically (see Chapter 2). It is also evident from our previous analysis of the data that Brazilian firms are committing to deeper levels of foreign operations in comparison to the investments of the $1980 \mathrm{~s}$, but that most international activities still remain related to exports.

Tables 1 and 2 present characteristics of Brazilian firms in the Global Players sample. They reinforce the belief that firms internationalise according to the premises of the Uppsala model. In Table 4.1, the levels of internationalisation are related to the years of experience in foreign markets. The average international experience of firms in the sample is 24.2 years. Around 14 percent of firms have activities that date back to the late 1960s. One firm reports starting foreign operations in the 1940s; another 
has had international business since the 1950s. Only 7.2 percent of the sample firms have five years or less of foreign experience. The data reinforces the assumption that experience has a direct and positive relationship with the levels of internationalisation achieved. Firms at higher levels of internationalisation have more experience in foreign markets.

Table 4.1: Foreign experience and international commitment, by number of firms

\begin{tabular}{|llll|}
\hline \multicolumn{4}{l|}{ Level of Internationalisation* } \\
\hline Experience & $\mathbf{0}$ & $\mathbf{1}$ & $\mathbf{2}$ \\
\hline 2-10 years & 2 & 6 & 6 \\
$11-25$ years & 1 & 5 & 14 \\
$>27$ years & 2 & 14 & 19 \\
\hline
\end{tabular}

Source: Global Players survey, 2007.

*Cumulative Values

Table 4.2 establishes another important resemblance between the behaviour of our sample and that expected by the Uppsala model: the association of psychic distance with foreign experience. According to the Uppsala internationalisation model, as firms accumulate experience in foreign markets, they become able to compete in locations that are less culturally and developmentally similar to their country of origin. The numbers suggest that the years of experience are positively related to the psychic distance of investments. Psychic level 1 refers to South and Central America and Africa; level 2 refers to North America and the European Union; and level 3 refers to the Middle East, Russia, and countries from Asia/Oceania.

Table 4.2: Psychic distance and foreign experience, by number of firms

\begin{tabular}{|llll|}
\hline \multicolumn{4}{l|}{ Psychic Distance } \\
\hline Experience & 1 & 2 & 3 \\
\hline$<5$ years & 5 & 0 & 0 \\
$5-10$ years & 4 & 0 & 3 \\
$11-25$ years & 7 & 3 & 8 \\
$>27$ years & 8 & 4 & 19 \\
\hline
\end{tabular}

Source: Global Players survey, 2007.

Note: Psychic distance is cumulative.

The key aspect to be investigated in this chapter is the relationship between different levels of internationalisation and competitive advantages. These advantages are built from the resources accumulated by firms, i.e. all "assets, capabilities, organisational processes, information, knowledge (...) that enable the firm to conceive of and implement strategies that improve its efficiency and effectiveness" (Barney, 1991: 101). These advantages are central for firm growth and for eventual expansion overseas. 
We also assess the influence of foreign experience on the levels of internationalisation, based on the assumption that capabilities and market knowledge are accumulated over time.

\subsection{Variables and Model}

To capture the advantages of Brazilian firms, we use the question in the Global Players survey that asks firms about their competitive advantages vis-à-vis those of their foreign competitors, labelling each according to its main scope. We apply a multinomial logit analysis to capture the possible effects of competitive advantages on the levels of internationalisation. A logit regression is the appropriate choice when the dependent variable has a dummy nature. In the models of this chapter the dependent variable takes the value 0,1 , or 2 according to the firm's commitment level. A multinomial rather than an ordered logit regression is applied because the different levels of internationalisation do not follow an ordered stage, meaning that movement from one level to another does not represent an equally measured event.

The main explanatory variables are the competitive advantages as perceived by the respondents. Table 4.3 lists ten competitive qualities of firms, grouped under five main themes: TECH for technology- and innovation-related, MGM for managerial, BRAND for brand, LABOR for skilled human resource, and NRES for resourcerelated advantages.

Table 4.3: Competitive advantages of Brazilian firms in Global Players sam-

\begin{tabular}{ll} 
& \multicolumn{1}{c}{ ple } \\
\hline Label & Competitive Advantage \\
\hline TECH & Modern, efficient equipment and plants \\
TECH & Innovation capability \\
TECH & Better support services \\
TECH & Competence in international niche markets \\
MGM & Competence in international supply chain \\
MGM & Ability to respond to expectations of foreign customers \\
BRAND & Brand international reputation \\
LABOR & Qualified labour at competitive cost \\
LABOR & Access to managerial, technical, or scientific pool of talent \\
NRES & Access to natural resources at lower cost or under favourable conditions
\end{tabular}

Source: Elaborated by the author with data from the Global Players survey, 2007.

We use the size of the foreign operations as a proxy of the size and also the extension of the internationalisation of the firm, for that we use the log of the foreign revenues reported by respondents. 
Table 4.4 lists the variables used in the multinomial regression.

Table 4.4: Variables used in multinomial logit tests

\begin{tabular}{|l|l|}
\hline Variables & Description \\
\hline Dependent: DOI & $\begin{array}{l}\text { Dummy that takes value 0 for no foreign activity, 1 for exports, and 2 for } \\
\text { FDI (including marketing, post sales, procurement, and productive activi- } \\
\text { ties) }\end{array}$ \\
\hline Laborcap & $\begin{array}{l}\text { Dummy with value 1 when respondents identify skilled-labour ad- } \\
\text { vantages }\end{array}$ \\
\hline Technology & $\begin{array}{l}\text { Dummy with value 1 when respondents identify technology- and innova- } \\
\text { tion-related advantages }\end{array}$ \\
\hline Brand & Dummy with value 1 when respondents identify brand-related advantages \\
\hline MGM & $\begin{array}{l}\text { Dummy with value 1 when respondents identify management-related } \\
\text { advantages }\end{array}$ \\
\hline NRes & $\begin{array}{l}\text { Dummy with value 1 when respondents identify natural-resource ad- } \\
\text { vantages }\end{array}$ \\
\hline Ln FOREV & Log of value of foreign revenues \\
\hline Lnexperience & Log of number of years of foreign experience \\
\hline services & Dummy for firms from the services sector \\
\hline
\end{tabular}

Source: Compiled by author using data from Global Players survey, 2007.

We run a multinomial logit model, where the base outcome is zero (no international activity), 1 is exports and 2 operations such as marketing, procurement, R\&D and manufacturing. We use the number of employees as a proxy for firm size and foreign revenues as a proxy for the size of the international operations; the log of the years that the firm has established foreign activities is a proxy for foreign experience.

The results of the model are presented in Table 4.6; Table 4.5 presents the correlations among variables used in the model. It is worth noting how to interpret the coefficients of a multinomial model. With zero as our base outcome, the results of the other levels must be understood in relation to the zero level. Therefore, the coefficients of each variable indicate how much an increase of one unit in that variable would impact the log-odds of the DOI level in relation to the base outcome.

Table 4.5: Correlation matrix

\begin{tabular}{|c|c|c|c|c|c|c|c|c|}
\hline & DOI & lexp & laborcap & innovation & Nres & MGM & lnFOREV & serv \\
\hline DOI & 1 & & & & & & & \\
\hline lexp & 0.1686 & 1 & & & & & & \\
\hline laborcap & -0.1822 & 0.0602 & 1 & & & & & \\
\hline innovation & $-0.3400 *$ & 0.0461 & $0.5393 *$ & 1 & & & & \\
\hline Nres & -0.1606 & 0.0943 & $0.4395^{*}$ & 0.219 & 1 & & & \\
\hline MGM & -0.2357 & 0.2325 & $0.4108^{*}$ & $0.5838^{*}$ & $0.3412 *$ & 1 & & \\
\hline lnFOREV & 0.193 & 0.0899 & -0.0543 & 0.0138 & -0.1287 & -0.0542 & 1 & \\
\hline serv & -0.1999 & $-0.3149^{*}$ & -0.024 & 0.0838 & -0.2633 & -0.024 & 0.0324 & 1 \\
\hline
\end{tabular}


Table 4.6: Results of the multinomial logit model

\begin{tabular}{|c|c|c|}
\hline \multicolumn{3}{|c|}{ Dendent Variable: DOI } \\
\hline VARIABLES & $\begin{array}{l}\text { EXPORT } \\
(\mathrm{DOI}=1)\end{array}$ & $\begin{array}{l}\text { FDI } \\
(\mathrm{DOI}=2)\end{array}$ \\
\hline lexp & $\begin{array}{l}0.403 \\
(1.594)\end{array}$ & $\begin{array}{l}0.226 \\
(1.576)\end{array}$ \\
\hline laborcap & $\begin{array}{l}-2.586 \\
(2.882)\end{array}$ & $\begin{array}{l}-0.669 \\
(2.823)\end{array}$ \\
\hline technology & $\begin{array}{l}17.72 * * * \\
(3.431)\end{array}$ & $\begin{array}{l}17.61 * * * \\
(3.735)\end{array}$ \\
\hline NRes & $\begin{array}{l}\mathbf{- 1 8 . 2 5} * * * \\
(4.613)\end{array}$ & $\begin{array}{l}-18.74 * * * \\
(4.634)\end{array}$ \\
\hline brand & $\begin{array}{l}16.96 * * * \\
(1.251)\end{array}$ & $\begin{array}{l}17.54 \\
(0\end{array}$ \\
\hline MGM & $\begin{array}{l}18.25^{* * * *} \\
(3.042)\end{array}$ & $\begin{array}{l}\mathbf{1 8 . 1 8}^{* * * *} \\
(2.889)\end{array}$ \\
\hline $\operatorname{lnFOREV}$ & $\begin{array}{l}\mathbf{0 . 3 7 7} \\
-0.257\end{array}$ & $\begin{array}{l}\mathbf{0 . 4 4 2 *} \\
-0.267\end{array}$ \\
\hline services & $\begin{array}{l}-\mathbf{2 0 . 6 0} * * * * \\
(3.956)\end{array}$ & $\begin{array}{l}-\mathbf{2 1 . 0 1} * * * * \\
(3.872)\end{array}$ \\
\hline Constant & $\begin{array}{l}14.90^{* * *} \\
(2.073)\end{array}$ & $\begin{array}{l}13.79 \\
(0)\end{array}$ \\
\hline Observations & 65 & 65 \\
\hline Log likelihood & -41.2588 & \\
\hline Prob $>$ Chi2 & 0.2633 & \\
\hline Pseudo R2 & 0.2673 & \\
\hline
\end{tabular}




\subsection{Results}

We applied a multinomial logistic regression to test the influence of the variables on different levels of internationalisation. The results of model provide information for the test of the hypotheses raised in the chapter. Technological capabilities had a strong positive and significant value, revealing that this capability increases the propensity of firms to engage in higher levels of internationalisation; and we therefore accept hypothesis 1 .

Hypothesis 2 refers to skilled labour as a competitive advantage of firms that internationalise. Skilled labour proved to be a crucial factor determining the internationalisation of Brazilian firms in developed countries and for that it seems reasonable to expect that it would also have a positive influence on higher degrees of international commitment. The variable, however, presented negative coefficients in the model for both levels, but results are not statistically significant, which prevents us from drawing definitive conclusions; hypothesis 2 therefore cannot be accepted.

Brand advantages had a positive and significant sign in level 1 of the multinomial model, indicating that brand recognition is a valuable asset for a firm to decide to enter foreign markets via exports. The coefficient was also positive for Level 2 of the model but not significant, and though it may be the case that brand increases the propensity of a firm to engage in a higher level of internationalisation, we cannot draw any final conclusion in this regard. Hypothesis 3 can therefore be only partially accepted.

Managerial capabilities (MGM) had a positive and significant sign in both levels of the model, meaning that such advantage increases the propensity of firms to engage in higher levels of internationalisation. Hypothesis 4 is therefore accepted.

The advantage of access to natural resources presented a negative and significant value in both levels of the model, meaning that this advantage does not increase the propensity of firms engaging in higher levels of internationalisation. This is an interesting result, since Brazil is known for creating important multinationals in the natural resources sector. The explanation for such results can be twofold: first, that the sample we are working with does not entirely represents these big players from the sector, and for those who may be in the sample, that the access to natural resources is not their main competitive advantage; also, it means that firms from the sample who are in the natural resources sector have a lower internationalisation level if compared to the big players from Brazil. Hypothesis 5 is rejected.

We expected that experience had a positive effect on higher levels of internationalisation. The results for this variable were positive, though not statistically significant and therefore no strong affirmations can be made about it. The fact that an increasing number of firms start their internationalisation process much earlier than predicted by models like the Uppsala and OLI makes any outcome possible in this regard. It seems that Brazilian firms are more traditional and internationalise as they gain experience and knowledge about foreign markets. Hypothesis 6 is not accepted. 
We controlled for the services sector because it concentrates a certain amount of firms in the sample (18 percent); besides, firms from the services sector may have a different pattern of internationalisation than firms from industrial sectors. Given that most services are consumed at the moment of production, this restricts the possibilities of firms from the services sectors to enter foreign markets with low commitment levels (Carneiro and Hemais, 2004).

The coefficient for services was negative and statistically significant. The result suggests that firms from this sector - at least those from our sample - are not very internationalised.

The log of foreign sales, also used as a control variable for both the size of the firm and the size of its foreign operations, had a positive sign in the model. It can also be considered a proxy for international experience, as it is reasonable to expect that revenues increase over time. Results were significant only for the second stage of internationalisation. This means large firms have a stronger propensity to engage in higher levels of commitment in the international market. It also means that, as firms gain market share abroad, they chose more committed modes of internationalisation.

It is worth stressing that three variables that were positive to the model, experience, technology and brand, are competences accumulated over time, and in this sense the results suggest that the stages of internationalisation model proposed by the Uppsala School are valid for Brazilian firms that internationalise. The influence of technology on higher levels of commitment in the international market signalizes that technology is a key ownership advantage - evidence that the OLI paradigm also has its room in explaining the internationalisation of Brazilian firms.

\subsection{Concluding Remarks}

The purpose of this chapter was to investigate whether different competitive advantages influence the level of internationalisation of Brazilian firms. Two different frameworks guided our analysis: the OLI paradigm and the Uppsala internationalisation model. The choice of this theoretical background was twofold. First, these theories emphasise the role of capabilities (especially in the form of knowledge) in the internationalisation process. In both approaches, knowledge and experience are considered to be capabilities. The cumulative nature of experience provides an important dynamic perspective of the internationalisation process. Second, earlier studies have shown the applicability of these approaches to firms in emerging economies, and in some cases to Brazilian firms (Carneiro et al., 2008). The positive impact of technology and innovation capabilities on competitive advantages were also corroborated by a previous study that related innovation to the export performance of firms in the Brazilian innovation survey, PINTEC (De Negri and Salerno, 2005).

With this in mind, this chapter sought to understand the commitment of Brazilian firms to higher levels of internationalisation. A multinomial model was applied in order to examine whether certain competitive advantages and accumulated foreign 
experience influence the movement of Brazilian firms towards deeper levels of international operations.

Results of the multinomial regression showed that technology, brand and managerial capabilities do increase the propensity of firms to commit to foreign markets at increasing degrees. These three competitive advantages characterize the ownership-advantages presented by the eclectic paradigm as one of the key factors for the internationalisation of a firm.

The case presented in the chapter shows that Brazilian firms have traditional firm advantages associated to their internationalisation process, that are very similar to the ones associated to the internationalisation of traditional multinationals.

A quite surprising result was that the model showed no positive relation of the variable natural resources with the propensity of firms to internationalise. A plausible explanation for that must be that firms from the sample do not associate this advantage as their main competitive asset for internationalisation. Even in the case of firms from intensive resource sectors, it may be the case that technology and innovative competences are identified as the central asset to be exploited - that was the result obtained from the analysis on the previous chapter of this thesis. Also, a growing number of firms are internationalising with the purpose of gaining access to natural resources in other countries, in special resources that are not available at home - for those firms, natural resources would hardly be mentioned as a strong competitive asset.

This chapter brought evidence that Brazilian firms are investing in value-adding activities abroad, taking more committed steps in the internationalisation process. It also evidenced, like the previous chapter, that firms are linking technological competences to their internationalisation process. This leads us to believe that Brazilian multinationals are not following a different or faster path than those crossed by the traditional multinationals of developed countries in the past. And, in this sense, we agree that the same models that once served as a framework for the internationalisation of the latter also explain the Brazilian multinationals of today.

Our analysis has some limitations. First, due to the static character of the date, which only allows us to carry out cross-sectional analysis. Information on the internationalisation levels over time would very much enhance our understanding of how Brazilian multinationals move towards further levels of internationalisation. The size of the sample also brings numerous limitations to statistical analyses. 



\section{CHAPTER 5 - INOVATION: ENHANCING THE COMPETITIVENESS OF BraziLIan MUlTinationals}

\subsection{Introduction}

Innovation has become a central issue to relate to firm growth and also in the dynamics of economic development and in the growth of firms (Lall, 1992; Freeman and Soete, 1997). The capability to innovate is a key determinant of the competitiveness of firms and often decides for their success or defeat in a market. While a microeconomic phenomenon, the results of the joint innovative efforts of firms determine the technological capabilities of their home country, and for that reason innovation is crucial for the catching up of emerging countries (Lall, 1992).

As competition widens with more and more industries achieving a global scope, firms find a stronger need to fight for markets, both domestically and abroad (Porter, 1990). At the same time, globalisation enhances communication and knowledge flows among countries. In this new competitive environment, innovation becomes more and more a result of the interaction and exchange of information among agents in a global network. Innovation occurs in more than one location and brings together different actors.

Because innovation is more and more a global rather than an isolated and localised activity, internationalisation is now a complementary, and perhaps essential, aspect of the discussion. In addition, evidence reveals that even the most traditional sectors are becoming more knowledge-intensive, and that the more knowledge-intensive a sector, the more internationalised it becomes (Brennan and Garvey, 2009).

In Brazil, innovation is a topic of interest not only to scholars, but also to policymakers and entrepreneurs interested in finding ways to expand markets and increase competitiveness. Chapter 3 in this thesis found data suggesting that Brazilian firms are strongly driven by technology-exploiting internationalisation, even when their investments target developed countries.

According to the analysis of the Global Players data carried out on Chapter 3, Brazilian multinationals are at a stage where their own technological assets (especially in the form of skilled personnel and managerial expertise) have a central role in internationalisation. Chapter 4 assessed the influence of firm-specific advantages (or capabilities) on the level of internationalisation. Moreover, it reinforced the importance of managerial capabilities in Brazilian multinationals, also suggesting that innovation and brand reputation are important characteristics for firms that want to move towards high levels of internationalisation.

The purpose of this chapter is to present the state of innovation effort among Brazilian firms, using data from the third edition of the Brazilian innovation survey, 
PINTEC 2005. The innovation survey provides a picture of the most innovative sectors, as well as the sources of knowledge and partnerships for innovation. We then draw a parallel among the most innovative sectors and the industries of the main Brazilian multinationals. The parallel is drawn to answer the underlying question: do innovative firms internationalise more than those that are not innovative? We believe so, and our main argument is that firms engaged in innovative activities have stronger competitive assets that enable them to expand their scope of operations to foreign markets. In other words, innovation is crucial for the competitiveness required to operate in foreign markets.

The argument is based on the observation of the international performance of some of the main Brazilian multinationals and the innovative efforts carried out by those firms. In particular, Petrobrás is a good example of a Brazilian firm with solid international operations and a remarkable performance in terms of innovation and technological development.

This chapter proposes to open a "parenthesis" from the analysis that was carried out in the previous two chapters, and move away from the Global Players data to use data from the Brazilian innovation survey. It changes the focus from internationalisation to analyse the innovative patterns of Brazilian firms. The use of anecdotal evidence from Brazilian multinationals, and a broader description of Petrobrás will, hopefully, corroborate the arguments raised that innovation is, indeed, a central asset to contribute to the international expansion of Brazilian firms.

The chapter is divided into four sections, including this introduction. The next section presents general information on innovation in Brazilian firms. Section 5.3 discusses some Brazilian multinationals and their innovative efforts, with an emphasis on Petrobrás. Section 5.4 provides concluding remarks.

\subsection{Innovation in Brazil: a portrait from the $3^{\text {rd }}$ Innovation Survey}

This section presents data from the third edition of the Brazilian innovation survey (PINTEC) carried out by the government statistics office, covering the period 200305 (IBGE, 2007). It provides important information on the general state of innovative activities carried out by Brazilian firms, the patterns of cooperation for innovation, and the main sources of information for innovation. PINTEC follows the Oslo Manual, developed by OECD and widely applied in European innovation surveys. Participation in the survey is mandatory to all firms in Brazil with more than 50 employees. The population of the 2005 edition of the survey is 89,162 domestic firms and 1,893 foreign firms, a total of 91,055 firms. There are 29,951 innovative firms in Brazil (32.9\% of the total). Regarding R\&D expenditures, domestic firms respond to a large share, totalizing more than USD 3 million (Table 5.1).

The concept of innovation activities used in the Brazilian survey goes beyond R\&D activities and includes training and the acquisition of machinery and equipment. Of the innovative firms, only 6,021 (20\%) declared that their R\&D activities played a strong or average role in innovation (IBGE, 2007). 
Table 5.1: Absolute R\&D expenditures, 2003-2005

\begin{tabular}{lllll} 
& & & \multicolumn{2}{c}{ (USD from 2005) } \\
\hline Source & Internal R\&D & External R\&D & Total & \% \\
\hline Domestic & $2,862,413$ & 234,120 & $3,096,533$ & $59.18 \%$ \\
Foreign & $1,576,684$ & 559,308 & $2,135,992$ & $40.82 \%$ \\
\hline
\end{tabular}

Source: IBGE (2007).

The most innovative sectors in Brazil, in terms of absolute expenditure, are: automotive, oil and gas, other transport equipment (including the aerospace industry), chemicals and pharmaceuticals, and machinery and equipment (Table 5.2). Domestic firms in these sectors have a significant share of total innovative efforts.

The distribution of R\&D expenditures by sector, and according to capital ownership, says much about the industrial structure built in Brazil since its early industrialisation phase, when a clear division of roles was established between the public sector, the private domestic sector, and the foreign sector. While the government controlled strategic resource-related industries, foreign investments were usually controlled by intermediary industries. This division of tasks between the domestic and foreign private sectors produced an industry where domestic capital dominated sectors that were less technologically intensive, and concentrated in commoditised products with little product differentiation. Foreign firms, on the other hand, became established in capital-intensive sectors, and accounted for around 50 percent of the manufacturing industry in the 1990s (Moreira, 1999).

Most innovative firms in Brazil carry out what is known as defensive innovation: innovating to follow competitors (the activity is new to the firm but already present in the market). Offensive innovation takes place on a smaller scale. Disruptive innovation - new to the world - occurs in only 0.4 percent of domestic firms and 4.3 percent of foreign firms (IBGE, 2007). 
Table 5.2: R\&D expenditure by industrial sector and capital ownership

\begin{tabular}{|c|c|c|c|c|}
\hline \multirow[b]{3}{*}{ Sector } & \multicolumn{4}{|c|}{ (in thousands of R\$) } \\
\hline & \multicolumn{2}{|c|}{ Domestic Firms } & \multicolumn{2}{|c|}{ Foreign Firms } \\
\hline & Internal R\&D & External R\&D & Internal R\&D & External R\&D \\
\hline Total Manufacturing & $3,877,494$ & 388,148 & $3,157,859$ & 555,922 \\
\hline Food and beverages & 187,929 & 13,067 & 105,621 & 6551 \\
\hline Tobacco & & 1612 & 20,792 & - \\
\hline Textiles & 53,568 & 2296 & 2033 & 781 \\
\hline Clothing & 27,936 & 1269 & - & - \\
\hline Leather products & 66,373 & 6672 & - & - \\
\hline Wood products & 19,785 & 644 & - & - \\
\hline Pulp and paper & 61,390 & 3102 & 23,975 & 3531 \\
\hline Publishing and printing & 8058 & 570 & 10,711 & - \\
\hline Oil and gas & 944,785 & 133,157 & 5138 & 1156 \\
\hline Chemicals and pharmaceuticals & 453,613 & 34,944 & 410,762 & 136,415 \\
\hline Rubber and plastics & 97,671 & 16,912 & 96,902 & 2922 \\
\hline Non-metallic materials & 83,750 & 7831 & 28,664 & 820 \\
\hline Metallurgy & 107,385 & 4120 & 70,022 & 15,405 \\
\hline Metal products & 56,421 & 4680 & 30,762 & 557 \\
\hline Machinery and equipment & 220,852 & 10,113 & 150,200 & 12,941 \\
\hline Informatics equipment & 54,753 & 21,997 & 98,628 & 13,066 \\
\hline Electric devices and machinery & 145,657 & 5568 & 249,181 & 11,763 \\
\hline Electronic equipment & 134,045 & 28,736 & 277,307 & 157,228 \\
\hline Medical instruments & 149,854 & 5757 & 20,477 & - \\
\hline Automotive and auto-parts & 173,233 & 21,654 & $1,519,320$ & 185,844 \\
\hline Other transport equipment & 750,091 & 58,838 & 24,079 & - \\
\hline Furniture & 80,345 & 4609 & 6558 & 4518 \\
\hline
\end{tabular}

Source: IBGE (2007).

The innovation rate is much higher for larger firms, as expected, because such firms have more resources to commit to expensive innovative activities (Table 5.3). Also, process innovation is more frequent than product innovation (IBGE, 2007). Although our data did not reveal innovation rate by capital ownership, earlier editions of the PINTEC survey revealed that the innovation rate of foreign firms was 62 percent, double the 31 percent of domestic firms. This is because more than 90 percent of small firms are domestic, while foreign firms are mostly large ( $>500$ employees).

Table 5.3: Innovation Rate by firm size

\begin{tabular}{lllllll}
\hline Employees & Innov. Rate & Product & $\begin{array}{l}\text { Product new (Nation- } \\
\text { al) }\end{array}$ & & Process & $\begin{array}{l}\text { Process new to sector } \\
\text { (Brazil) }\end{array}$ \\
\hline $10-49$ & 28.9 & 17.0 & 2.1 & 23.1 & 0.9 & \\
$50-99$ & 40.6 & 22.8 & 3.7 & 33.2 & 1.2 & \\
$100-249$ & 55.5 & 31.1 & 6.5 & 44.8 & 3.8 & \\
$250-499$ & 65.2 & 35.9 & 9.4 & 56.0 & 6.1 & \\
$>500$ & 79.2 & 58.1 & 33.4 & 68.4 & 27.1 & \\
\hline
\end{tabular}

Source: Compiled by author using data from IBGE (2007). 
Among Brazilian firms, cooperative arrangements for innovation are still rare. Cooperative firms comprised 7.2 percent of innovative firms in 2005 (IBGE, 2007). Cooperative arrangements are especially important because of the pace with which information becomes obsolete. Innovation is also a costly and risky business, and the involvement of more agents may increase the chances of success through the use of more sources of knowledge, or at least lower the risks and costs for individual agents (Duysters and Hagedoorn, 2000).

Regarding the sources of information for innovation, Brazilian firms rely on clients and suppliers; competitors are the third source. Universities are sources of information for only 4 percent of domestic firms and 12 percent of foreign firms.

Data from PINTEC indicates that domestic firms use third parties as sources of information to a lesser extent than foreign firms operating in Brazil do. This suggests that firms are not deeply engaged in innovative networks and are not exchanging information with and obtaining knowledge from foreign partners to a significant extent (IBGE, 2007).

To summarise, the Innovation Survey reveals a scenario in which innovation and cooperative arrangements among agents have great potential for growth. Brazilian firms still have lower rates of innovation and cooperation than those observed in developed nations. It is worth stressing the role of joint efforts (cooperative agreements, innovation joint ventures, and other arrangements) for a more efficient flow of knowledge in the economy and a more aggressive presence of Brazilian firms in a global innovation network. It is an important step towards more internationalised firms. The next section discusses the role of innovation for the largest and most internationalised Brazilian firms.

\subsection{Brazilian Multinationals and Innovative Activities}

Internationalisation theories such as Dunning's eclectic paradigm emphasise the role of innovation in boosting value generation (Dunning and Lundan, 2008). It is therefore reasonable to expect that innovation plays an important role in the trajectories of Brazilian multinationals, determining and explaining their competitiveness in global markets.

An interesting study assessed the role of innovation in the internationalisation behaviour of domestic firms, based on data from the Brazilian innovation survey. Arbix et al. (2005) used the innovation survey to assess the scale and efficiency of domestic firms with foreign investments. This group represents only 0.4 percent of Brazilian firms, but they account for 25 percent of revenues and 36.5 percent of exports of industrial firms (Arbix et al., 2005: 179). Their export share almost equals that of foreign firms in Brazil, 37.9 percent of the total, but the foreign firms account for just 2.2 percent of all industrial firms.

Arbix et al. (2005) link export performance and scale efficiency to the innovative behaviour of internationalised domestic firms. They argue that innovation is a central characteristic determining the achievement of premium prices for exports. Innovation 
was positively correlated with FDI in domestic firms; moreover, premium prices for exports were achieved by domestic internationalised firms selling to specific markets (the USA and Europe). The main conclusion of the study is that innovation plays a central role in the internationalisation of Brazilian firms.

A study carried out by Prochnik et al. (2007) sought a relationship between innovation activities and the degrees of internationalisation ${ }^{16}$ of Brazilian firms. The number of employees with a masters or $\mathrm{PhD}$ degree involved in $\mathrm{R} \& \mathrm{D}$ activity is used as a proxy for the innovation of the firm. The authors found that the share of innovative firms tends to increase with the degree of internationalisation, and that innovation tends to be more aggressive the higher the internationalisation of the firm. Moreover, the human resources in internationalised firms are more directed to R\&D activities than those in other groups of firms. Another interesting finding is that the innovation model applied by internationalised firms starts with product innovation based on employees' technical skills (Prochnik et al., 2007: 18). This is similar to the findings of our earlier chapters: the innovative assets of Brazilian multinationals are embedded in their human resources.

Inspired by the findings for Brazilian multinationals, we consider a group of firms ranked among those most internationalised in Brazil, searching for an indicative link between their internationalisation and innovative efforts. Table 5.5 presents a ranking of the most internationalised Brazilian firms, calculated using the methodology proposed by UNCTAD in their transnationality index ${ }^{17}$.

It is clear from our data that Brazilian firms do not have internationalisation levels comparable with those of firms from developed countries (Table 5.5, column 3). GE, BP, Toyota, and Nestlé (all large multinationals from the developed world) have transnationality indices of 51.4, 79.9, 51.9, and 86.6, respectively. Cemex, LG, and Tata Steel (multinationals from emerging economies) have indices of 82.2, 55.4, and 71.8, respectively (UNCTAD, 2009).

The numbers show that Brazilian firms are placing their investments in a growing number of countries. Eleven of the top thirty Brazilian multinationals are present in more than ten countries, which suggests that they are moving beyond their neighbouring countries, which are natural markets because of geographic proximity and cultural convergence.

We now return to the data on $R \& D$ expenditure by industrial sector presented on Table 5.2. R\&D expenditures are a proxy for the innovative efforts carried out in each of these sectors, because these data are available by sector. Innovation includes factors other than R\&D activity, but it is common to use the latter as a measurement of the former. From the table the performance of four sectors stands out: aerospace, oil and gas, vehicles and auto-parts, and chemicals. These sectors are represented by Embraer, Petrobrás (among the largest Brazilian multinationals in terms of foreign assets), Sabó, Marcopolo, and Natura, among other firms (Table 5.5).

\footnotetext{
${ }^{16}$ The degrees of internationalization considered in the study are $0=$ domestic firms; $1=$ exporting firms with no FDI; 2 = firms that export and have FDI.

${ }^{17}$ The TIndex is composed of the sum of ratios of foreign to total employees, revenues, and assets.
} 
Table 5.5: Top Brazilian multinationals, according to transnationality index (TI)

\begin{tabular}{|c|c|c|c|c|c|c|}
\hline Company & Sector & TI & Employees & Assets & Revenues & Countries \\
\hline JBS Friboi & Food & 0.684 & 0.654 & 0.559 & 0.84 & 4 \\
\hline Odebrecht & Group & 0.630 & 0.556 & 0.559 & 0.774 & 14 \\
\hline Gerdau & Metallurgy & 0.559 & 0.492 & 0.609 & 0.527 & 13 \\
\hline Metalfrio & Electronics & 0.496 & 0.325 & 0.687 & 0.477 & 5 \\
\hline Coteminas & Textile/clothing & 0.442 & 0.28 & 0.195 & 0.913 & 6 \\
\hline Ibope & Services & 0.425 & 0.613 & 0.33 & 0.331 & 15 \\
\hline Sabó & Autoparts & 0.404 & 0.346 & 0.385 & 0.482 & 6 \\
\hline Magnesita & Mining & 0.383 & 0.23 & 0.642 & 0.277 & 6 \\
\hline Marfrig & Food & 0.343 & 0.292 & 0.262 & 0.475 & 7 \\
\hline Ambev & Beverages & 0.301 & 0.41 & 0.12 & 0.374 & 13 \\
\hline Tigre & Constr. material & 0.296 & 0.227 & 0.455 & 0.205 & 9 \\
\hline Vale & Mining & 0.290 & 0.247 & 0.389 & 0.235 & 33 \\
\hline Artecola & Chemical & 0.277 & 0.215 & 0.306 & 0.31 & 5 \\
\hline Marcopolo & Vehicles/autoparts & 0.252 & 0.259 & 0.163 & 0.199 & 9 \\
\hline Lupatech & Metal-mechanics & 0.234 & 0.267 & 0.185 & 0.25 & 3 \\
\hline WEG & Capital goods & 0.212 & 0.166 & 0.176 & 0.354 & 22 \\
\hline Gol & Services & 0.206 & 0.31 & 0.588 & 0 & 8 \\
\hline Embraer & Aerospace & 0.203 & 0.123 & 0.389 & 0.096 & 5 \\
\hline Duratex & Group & 0.199 & 0.462 & 0.041 & 0.094 & 3 \\
\hline Itautec & IT & 0.183 & 0.074 & 0.197 & 0.284 & 9 \\
\hline Camargo Correa & Group & 0.177 & 0.192 & 0.162 & 0.178 & 12 \\
\hline Stefanini & IT & 0.177 & 0.163 & 0.183 & 0.184 & 15 \\
\hline Votorantim & Group & 0.168 & 0.121 & 0.222 & 0.161 & 14 \\
\hline A. Gutierrez & Construction & 0.163 & 0.087 & 0.114 & 0.289 & 17 \\
\hline Tupy & Metallurgy & 0.163 & 0.04 & 0.198 & 0.288 & 3 \\
\hline CI\&T & IT & 0.157 & 0.034 & 0.166 & 0.27 & 3 \\
\hline TAM & Services & 0.121 & 0.056 & 0.06 & 0.306 & 1 \\
\hline ALL & Logistics & 0.119 & 0.291 & 0 & 0.066 & 1 \\
\hline Petrobrás & Oil \& gas & 0.110 & 0.091 & 0.113 & 0.124 & 25 \\
\hline Natura & Cosmetics & 0.104 & 0.23 & 0.025 & 0.058 & 7 \\
\hline
\end{tabular}

Source: Compiled by author using data from the Ranking FDC 2009 das Multinacionais Brasileiras and from Valor Multinacionais, 2009.

By highlighting the top R\&D spenders from Table 5.2 and some of the top Brazilian multinationals from Table 5.5 we want to address the following question: is there a relationship between innovation efforts and internationalisation, and in particular successful global expansion? The story of outstanding firms among the top Brazilian multinationals suggests that innovation is a strong competitive tool that fosters international success.

In the chemical sector, Natura, Artecola, and Braskem (part of the Odebrecht group) are among the top multinationals from Brazil ${ }^{18}$. Natura is one of the most fre-

\footnotetext{
${ }^{18}$ Separately from the Odebrecht group, Braskem has the 42nd position among the multinationals.
} 
quently studied companies from Brazil, for both its innovativeness and its efforts to penetrate foreign markets.

Natura is a good example of the point we want to raise in the chapter, the association of internationalisation success and innovativeness. Natura started international operations through exports, replicated its direct sales approach in Latin American countries and, in 2010, announced that it would start producing in three Latin American countries through outsourced manufacturing (PIB,2010). The firm owns distribution centres in five Latin American countries and operates in other two with partnerships with local companies. In 2005, Natura opened a concept-store in Paris to introduce the firm's products and values into the European market (Araújo and SerpaBlundi, 2005; Natura, 2010). The company has an innovative and environmentally sustainable strategy of exploring ingredients from the Amazon, selling refillable products, and using Brazilian diversity as a brand that is slowly making headway in the minds of foreign customers. With an average of a new product or concept every three days, Natura introduces over 200 new products each year (Araújo and SerpaBlundi, 2005). The company works with Brazilian universities for product development, a strategic approach that allows successful innovations with shared costs. The project Natura Campus has been carried out since 2007 with the support of state innovation agencies, and has the goal of enhancing the university-firm cooperation for innovation and research development (Natura, 2010). In 2009 the company invested 2.6 percent of revenues (over USD 60 million) into innovation-related projects (Natura, 2010).

It is interesting to observe that the automotive industry, by far the sector with the largest R\&D expenditure (although it is concentrated in foreign multinationals operating in the country), has great potential for knowledge or technological spillovers through the industry-value chain. Firms can benefit from cooperative arrangements with the goal of generating an innovation that is welcomed by both parties (Blomström and Kokko, 1998; Consoni, 2004; Dunning and Lundan, 2008). Brazilian autopart firms have achieved competencies through client-supplier linkages created by the presence of foreign firms in the local market; domestic auto-part manufacturers have also been driven to foreign markets as part of a follow-the-client strategy.

Sabó is an auto-part firm that developed its own technological capabilities to satisfy client needs. The company started its internationalisation in the 1990s as part of a follow-the-client plan. It was one of the few domestically owned firms to survive the massive entry of foreign firms into the sector in the 1990. Its survival was largely due to the firm's willingness to explore the opposite direction, acquiring companies in Germany, Hungary, and Argentina to strengthen its market presence and technological competence. Sabó's auto-parts are used by almost all automotive industries around the world (Gallina et al., 2005). The company invests around 6 percent of its revenues into $\mathrm{R} \& \mathrm{D}$, and has accumulated prizes for several innovations, one of them carried out in a joint research project with a German university (Gallina et al., 2005).

Embraer, the Brazilian aircraft manufacturer, is known worldwide because it successfully entered the small-jet segment. The company did not have the technological expertise to build small aircraft, but with demand for military jets shrinking, Embraer 
put into practice a reverse-outsourcing manufacturing model. This strategic innovation put the company among the leaders in regional-jet manufacture (Casanova, 2009). Throughout its history, the company always had the support of public research institutes and partnerships with universities for technological development. Cooperative agreements and joint ventures have been used to enter restricted markets like China (Goldstein, 2008). The company invested over USD 200 million in R\&D activities in 2009, 3.7 percent of sales revenues (Embraer, 2010).

Firms from other sectors also have internationalisation strategies supported by their innovative efforts. For instance, WEG, an electric-engine manufacturer (sixteenth in the ranking of top Brazilian MNCs), is an internationalised firm in the sector of capital goods. It is also the only domestic firm in that sector to be among the top 100 exporting companies. The company started internationalisation to follow its customers' needs. The acquisition of technology through partnerships with competing firms in Europe provided the means for accumulating its own technological capabilities, until then non-existent. The firm then entered a new phase of technological development, developing its own technology in cooperation with consultants.

Next, we present the case of Petrobrás, an interesting illustration of the combined role of innovation, cooperative arrangements in R\&D in building a successful Brazilian multinational.

\subsubsection{Petrobrás: A Brazilian Multinational Developing Technology at the Frontier ${ }^{19}$}

Petrobrás was established in 1954 by president Vargas under the Import Substitution Industrialization (ISI) programme, which aimed to turn the Brazilian economy more independent from international ups and downs. The state owned company was granted exclusive rights over the exploitation and production (E\&P) in the domestic territory a monopoly broken only in the late 1990s, when the country's economy adopt a more liberal positioning in terms of trade and investments with the rest of the world. It is currently the largest Brazilian company in terms of assets, revenues, being also the top Brazilian exporting company (Revista Exame, 2010). In 2009, the company had around USD 103 billion in revenues, and net profits of over USD 16 billion (Table 1). In 2009 , Petrobrás rose to the $4^{\text {th }}$ place among the world's largest energy company, with a market value of USD 199.2 billions (in 2008 Petrobrás was ranked 9) (PFC Energy, 2010). Petrobrás is also one of the largest multinationals from Brazil, with external revenues of over USD 5 billion (Chevarria, 2006).

The foundation of Petrobrás, along with other state-owned enterprises in basic industries (such as Vale in iron ore and CSN in steel), was one of the cornerstones of the import substitution industrialization strategy carried out in Brazil, with the aim of enabling the country to reduce its external dependence in basic industries. Oil has always been a political matter, which legitimized the need of a strong and state controlled enterprise to manage the country's resources. The 1970s oil crises gave new

\footnotetext{
${ }_{19}$ This section is based on Carvalho, F. (2012), An oil giant from the emerging world - Petrobras. In: Looney, R. (ed.), Handbook of oil politics. London, Routledge.
} 
dimension to the political side of the oil question, also revealing that that the Brazilian energy policy had failed until then to make the country independent from foreign oil sources. In this context Petrobrás increased its strategic importance and focused on: a) the development of specific technological capabilities for prospecting oil in deep waters (due to this particular location of most Brazilian reserves); b) the search for alternative energy sources. The international expansion started in 1972, with the creation of Braspetro. At the time oil imports totalized 80 percent of domestic demand. Its international branch had, at that time, the main purpose to assure domestic supply. The national production in those years supplied only 17 percent of the internal demand, the equivalent to 184.000 barrels per day (bpd) (Chevarria, 2006).

The initial expansion focused on Latin American countries, followed by Africa (Angola, in 1979- where similar exploration conditions existed) and to the Gulf of Mexico. The quick technological catching up with the leading oil firms in the 1970s and the development of its own technology for deep-water extraction have been the cornerstone of Petrobrás' international expansion. Nowadays, the company holds more than 100 production platforms and 16 refineries (in Brazil, Argentina, USA and Japan), being directly present in 27 countries (Petrobrás, 2010). The core operations remain in Latin America, mainly Argentina, where the company invests in search for synergies (scale and scope economies) with its operations in Brazil (Chevarria, 2006; Dalla Costa and Pessali, 2007).

After a long time monitoring and limiting the operations of foreign firms in their national reserves, governments were pressed by technological and fiscal requirements to open up the sector to FDI (Aikut and Goldstein, 2009). The same happened in Brazil under the Cardoso government (Carvalho and Goldstein, 2009). Since then, around 50 new companies have established operations in Brazil; among them, a series of small enterprises started operating in the sector, in the field of onshore exploration (Estado de Sao Paulo, 2007). Regulatory controls regarding exploration and production licenses are since then implemented by ANP (National Petroleum Agency), an institution under autarchic management. The role of Government has been reshaped, from production and promotion of the sector to regulation and surveillance. Concession rounds are now on their ninth phase, and today there are 71 concessionaires operating in Brazil (35 of which are foreign investors). In 2010 production reached 1.97 million bpd, a rise of 6 percent compared to the previous year (Petrobrás, 2010).

Today the government is the major owner of the company -32.1 percent of the social capital, and 57.8 percent of voting shares. The company has recently made a public offering of shares, in order to capture funds for further investments in the presalt exploration. Over 2 billion shares were put in the market and the company capitalised around USD 70 billions.

The recent discoveries of oil in the pre-salt layers have shifted the focus of Petrobrás expansion towards a domestic challenge - to develop technology to make such reserves profitable (Economist, 2010).In these new discovered sources, Petrobrás has operated long term tests (LTDs) in consortiums with foreign oil companies, such as BG Group and Repsol in the Santos basin, BG Group and Petrogal in the Tupi ba- 
$\sin$. The LTDs have reached already an average of 20 thousand bpd. In 2010, new presalt reserves were announced in the Brazilian coast.

The focus on the pre-salt exploitation, however, did not extinguish investments overseas. In 2009 the company started refining operations in Japan, where it will provide gas for a compound with 3 percent of ethanol to be consumed in that country. In Portugal, Petrobrás established an office to be run alongside its exploration activities in the Portuguese coast. In total, Petrobrás invested over USD 174 billions in 2009, mostly in the E\&P segment (Petrobrás, 2010).

Next we present the technological achievements of Petrobrás over the years, and how they contributed to the expansion of its businesses to foreign markets. We also stress the technological challenges posed by biofuel production and the exploration of the recent pre-salt reserves.

\section{Technological capabilities and international expansion}

The reason why Petrobrás achieved such remarkable position among the leading world oil producers derives from the successful development of a state-of-the-art set of techniques to explore specific features of Brazilian reserves. Thanks to intensive R\&D efforts, the accumulation of technological capabilities evolved from an initial set of incremental innovations from imported technologies to the development of its own set of techniques (Neto and Dalla Costa, 2006).

Throughout its history, Petrobrás accumulated strong capabilities in deep-water extraction, for which it has received several industry awards (Dalla Costa and Pessali, 2008). Its technological accumulation derived from the fact that oil reserves in Brazil are in deep and ultra-deep waters, which from the start required special extracting expertise.

The tipping point in the technological development of Petrobrás took place when the company shifted its focus from downstream towards upstream activities. It took place in the early 1980s, when offshore exploration was at the technological frontier of the oil industry. The choice for prioritizing this source of oil led the company to develop technological efforts much more significant than what had traditionally been held so far (Furtado, 1997).

The accumulation of technological capabilities in the $1980 \mathrm{~s}$ is a 'innovation jump'; in fact, Petrobrás jumped from the absorption and reproduction of external technologies already in use to the development of production systems in deep waters, prompted by huge discoveries of oil at depths from 400 to 2000 meters - the biggest ones found at that depth at the time (Furtado, 1997). Such technological prowess did not take place in a flash, however. Firstly, while a purchaser of external technologies, the company made firm investments in human resources capabilities - in those who would have to purchase and apply the technologies. Over time such efforts slowly consolidated into industrial research, towards what would later become an R\&D center. Cenpes was set up in 1966 as an outcome of the training activities of the human resources that operated the key technologies. CENPES helped the transition of experimental technologies to industrial applicability, specially the development of the float- 
ing production system applied for increasingly deep-water extraction (Furtado, 1997; Furtado and Freitas, 2000). In 2009, the institute received USD 872 millions for technological development projects (Petrobrás, 2010).

Offshore technologies are frontier knowledge, and the possibility to explore the new found fields in deep waters presented to Petrobras the opportunity to change the course of its technological development. The company's decision to develop in-house this still unavailable technology was crucial to the consolidation of its innovative capability.

Such an achievement was possible due to extensive research efforts carried out in cooperation with institutes and universities in Brazil and abroad. Those foreign partnerships evolved from co-sponsorship to Petrobrás establishing itself as leading articulator of the innovation process (Furtado and Freitas, 2000). The strategy of focusing on offshore-drilling technologies has seized its benefits: while in 1987 only 1,7 percent of production came from the sea, in 2000 this amounted to 55 percent (Bruni, 2002).

Brazilian Universities have been important providers of high quality human resources to the company. Results of the R\&D efforts have been quite impressive. In terms of R\&D expenditures, Petrobrás ranked as the 5th world oil company (DTI, 2006), and the $3^{\text {rd }}$ oil firm in terms of R\&D expenditures, with over USD 1 billion spent in R\&D activities in 2009, (a $7 \%$ increase in relation to the year before) (DTI, 2009). In terms of R\&D outputs, Petrobrás is similarly impressive. It is the Brazilian enterprise with more patent applications, and also with more patents granted in the US Patents Office (USPTO). Until 2005, the company also held the largest number of patents from the Brazilian Patent's Office (INPI) (222 in the period 1990-2001). On average, Petrobrás files 80 patent claims per year and the company has already reached the $1000^{\text {th }}$ patent filed.

Whereas the company's initial expansion in foreign markets was markedly driven by the need to assure the Brazilian independence of foreign oil, recent movements have different objectives. The emphasis now is towards business expansion and conquering new markets; diversifying in the downstream segments is a new directive of the company's international strategy. This goes in line with its aim to become a global, integrated company in the energy sector as a whole. The expansion of downstream investments also has the purpose of exploring and expanding the brand of Petrobrás petrol throughout the world. The acquisition of refineries in the USA and Japan has this specific goal. Petrobrás is searching for large profits from refining its excess capacity and operating in the downstream segment.

The rise of foreign investments from Petrobrás in the 2000s reflects a new moment in the history of the company and a change in trends in the oil market in Brazil. First, the end of the monopoly in oil exploration in 1997 and the openness to foreign investors put the firm in a new, competitive market. Since then its executives face the expansion overseas as a source of growth to the firm (Chevarria, 2006). Second, the country's achievement of self-sufficiency in oil supply, in April 2006, after the opening of another platform for deep water exploration at the Bay of Campos (RJ), have expanded investment strategies to beyond the search for resources, but also aiming to 
new markets for distribution of by products, refining and logistics (downstream activities).

The international efforts are proving to be positive: while in 2000 there were still no refining activities abroad, in 2002 the refining capacity was of 100 thousand bpd; in 2009, it reached 140.7 thousand bpd (Petrobrás, 2002; 2010). The refining capacity is concentrated in the Southern Cone of America, one of the strategic areas of action by the company.

Recently, Petrobrás is targeted to increasing its production capacity in ethanol and biodiesel, applying strong efforts in research for alternative energy sources. Ethanol production and exports had its kick start in december 2009 with the acquisition of 40 percent of shares in a sugarcane powerplant in the state of MG (Petrobrás, 2010). A big challenge lies ahead for Brazil to conquer technological supremacy and establish itself as a major producer of this biofuels in the global market. The company aims to grow its capacity in ethanol production by 45.5 per cent a year, reaching exports of 4759 thousand cubic feet by 2012 .

The efforts in ethanol production are part of a new strategy followed by the company to become a major energy player. As oil reserves have a deadline, conflicts among producers are always a threat, and environmental pressures demand for alternative energy sources, Petrobrás is now redefining its business. Nowadays the company has operations in hydroelectrical energy and biodiesel, besides its traditional business in oil, natural gas and diesel (Petrobrás, 2010).

Technological prowess has rendered the company a valuable brand performance both domestically and internationally. It is among the top 10 most valuable brands in Brazil, and is the only Brazilian brand to show in the Millword Brown Optimor report of most prominent brand names of the world (Economist, 2010a).

Petrobrás is an exemplar emerging company where innovation had an important role in the consolidation of its success, both domestically and abroad. Technological capabilities have been developed as part of a strategic plan of the company. As Dantas and Bell (2006) stress, “(the company's capabilities) evolved from those of an imitative technology-user to those of a leading player at the international innovation frontier" (2006: 9). Moreover, a change in the Brazilian regulatory scenario for oil investments has fostered a further internationalisation strategy, in order to strengthen its competitive position. The accumulation of technological capabilities gave the company opportunity to explore deep water oil sources and established Petrobras as a key player in the oil sector worldwide. The move towards the Gulf of Mexico (where the company owns more than 170 deep water blocs) and the western shore of Africa are the result of the capabilities in offshore exploitation, since these sites are at the frontier of deep shore exploration in the world (Chevarria, 2006).

The national relevance of Petrobrás has taken a new dimension since the announcement that the country became self-sufficient in oil supply in 2006, after the inauguration of deep-water exploration in the Campos basin. Since then, and along with the discoveries of pre-salt reserves in the Brazilian coast, the country is building potential to become a major oil producer. Whereas the Tupi field discovered in 2007 will add 5 to 7 billion barrels of crude oil and natural gas production (Carvalho and 
Goldstein, 2009), the pre-salt reserves might add over 1 million barrels per day by 2017 (Petrobrás, 2010).

Today the biggest challenge for Petrobrás is the development of breakthrough technology for the exploration of the pre-salt reserves. Making the activity profitable will take extra innovative efforts, and demand great amounts of highly skilled workers; it will also be imperative to prove that the accomplishments in the new reserves are environmentally sustainable (Economist, 2010b). So far, the company's directors and the Brazilian government have been optimistic with the promises of abundant sources for the future. Several partnerships with universities, research institutes and other companies in related industries are under way, looking for solutions in drilling wells, storage and transportation - a CENPES initiative denominated Prosal (Technological Programme of the pre-salt) (Gouveia, 2010; Petrobrás, 2010). Investments related to the pre-salt discovery are projected to be of around USD 28 billions per year, at least until 2014 (Época Negócios, 2010).

\section{The role of policies and state ownership in oil companies}

The oil sector is not neutral to government decision-making, for the very reason that oil is a key, strategic asset, of which the economic prosperity of most nations depends upon. The national ownership of oil firms - mostly observed in developing and emerging economies - has also shaped the weigh of their influence in the national economy. In this section we will approach the role of the government in the performance of Petrobrás, both as an energy company and as a Brazilian multinational. Such role is rooted in the import substitution regime, which privileged basic industries as the drivers of economic growth and kept them safely in the hands of the State. Technological capabilities were developed in accordance to this strategic weigh of the industry, and were central for the establishment of the company as a global energy player.

Especially after the year 2000, Brazilian firms intensified their internationalization processes, with important acquisitions of firms from developed countries. In the case of Petrobrás, this process was strengthened due to the redesign of energy policies (Sennes and Narciso, 2009). Since the 1990s, Brazil has moved from a selfsufficiency policy towards an integrated, energy security approach as its central strategy, which took shape through the government's designs for Petrobrás. In line with this changing perspective, internationalization, verticalization and investments in finding better energy sources have come to the heart of the company's strategic plans.

The role of the government in the development of what Petrobrás came into being has several facets. To begin with, the choice of oil \& energy as a key driver of the country's economic industrialization, during the import substitution industrialization process carried out the 1950s was crucial for the pursuit of technological development required in order to access the domestic oil reserves. In this sense, it is hard to detach the presence of the government from the impressive technological trajectory of the company - also developed with consistent partnerships with public universities and research institutes. 
The internationalization of Petrobrás was also a strategic political decision, with the purpose of keeping the country safe of the economic imbalances originated from international oil crisis. In several occasions, the country was fast and broke blockades from the rest of the world towards key oil reserves in the world, such as Iraq (Goldstein, 2010).

In terms of internationalization, the role of the government is restricted to the strategic search for oil sources at the early global expansion of Petrobrás. Policies to foster internationalization of Brazilian firms have only recently entered the government's agenda, as part of a strong policy aiming to boost export performance and improve competitiveness through $\mathrm{R} \& \mathrm{D}$ expenditures in new strategic sectors (Almeida, 2009). Until then, in Brazil the predominant vision among the government was that foreign investments from domestic companies represented a crowding out of capital, investments and employment, and therefore were very harmful to the domestic economy. This vision has been reverted by evidence, not only in Brazil but also throughout the world, that internationalised firms perform better and possess better technologies and human resources, and their exports achieve a better profitability due to these advantages (De Negri et al., 2005).

In resume, Petrobrás became a national global player due to relying on a strong competitive asset: its deep waters exploration technologies, which have been developed from the specific circumstances present in the Brazilian oil reserves. The role of the government in the process was in picking the oil sector as strategic for industrial development and providing means for the building of a scientific and technological network to enable the development of the required capabilities. There were no direct incentives in internationalization apart from the strategic and political purposes of reaching key oil sources.

It is useful to counterbalance the case of Petrobrás with that of the state oil companies of China. In the latter case, the government had a major role in creating big global companies from the start, since the country lacked both oil reserves in sufficient amounts for its demand and the technological capacity necessary to explore the sources that they own (Carvalho and Goldstein, 2009). In this sense, Petrobrás' international expansion is highly technology-exploiting by nature, whereas the Chinese expansion had a strong technology-seeking purpose.

Petrobrás is of crucial importance in the Brazilian political scenario and is no rarely the reason of political distress. With a budget bigger than most ministries, the company responds for a third of all investments foreseen by the Growth Acceleration Plan - PAC, an equivalent of over USD 80 billions (Revista Exame, 2010b). For that reason, every little movement in the company's administration is followed, and investment plans, governance structure and indebtedness levels are subject to severe public scrutiny. 


\subsection{Concluding Remarks}

The purpose of this chapter was to bring together data on the innovative activities of Brazilian firms and to establish a link between innovation and internationalisation. We highlighted some highly innovative sectors and the presence of internationalised companies in those sectors. Firms such as Natura, Embraer, Sabó, and Petrobrás are some of the most innovative industries in Brazil and, not coincidentally, are among the top multinationals from Brazil. We suggested that internationalisation-especially if it is understood as expansion and the accumulation of competitive advantages - is strongly influenced by innovative and technological efforts.

This argument was presented in earlier studies using data from the Brazilian innovation survey - PINTEC, where innovation proved to have a positive influence on internationalisation. Innovative firms not only have better export performance but are also more internationalised than non-innovative firms (Prochnick et al., 2007). Chaper 4 of this thesis also found that higher degrees of internationalisation are related to the innovative efforts of firms and to intangible knowledge embedded in the human capital of Brazilian multinationals.

It is common knowledge that the largest global multinationals are also highly innovative firms. Innovation is one of the main drivers of firm growth, market share growth, and successful competition, both domestically and internationally. We stress that the same applies for the Brazilian firms that are successfully gaining an international presence. They are innovative firms with strong technological development efforts. They also use cooperative arrangements to develop new technologies, products, and processes with a diverse range of partners, some of them from abroad.

The world economy is becoming more and more connected, and national boundaries are less and less relevant. Competition takes place globally, and so does innovation and knowledge creation. The successful firms of the future, from Brazil and elsewhere, will be those that succeed in providing global markets with their products, and that gathers knowledge from all over the world to provide them the inspiration for innovation. 


\section{Conclusions}

The purpose of this thesis was to draw a picture of the Brazilian firms that took the path of internationalisation to become global players. The internationalisation of firms from emerging markets has raised interest in the academia, from both international business and economics scholars. Numerous studies have tried to understand their pattern of internationalisation, and a central question has been raised by many of these studies: can extant theories explain emerging multinationals in their entirety? Or do we need new theories that take fully account of their distinct features?

Our interest in the case of Brazil was driven by the prominence of this country in the global scenario and to the huge expectation that have been addressed to it as a "promising nation", "country of the future". Brazil is the $6^{\text {th }}$ largest economy in the world, in terms of GDP, but this importance is not translated into an outstanding internationalisation of its firms and has been surpassed by South Corea and China over history.

To better understand the trajectory of Brazilian multinationals, this thesis first adopted a macroeconomic perspective in order to investigate the economic characteristics of the country that might have determined which firms would become global champions. Later, we look at micro-level data, a survey of Brazilian firms, with the purpose to understand what competitive advantages are identified as important assets for internationalisation.

Innovation, the outcome of technological accumulation, is considered a central competitive advantage of firms, and a key factor to determine the economic growth of countries. As a phenomenon that takes place at firm level generating a macroeconomic outcome, the role of innovation in the internationalisation of Brazilian firms is a central subject of investigation.

We also carried out a statistical test to investigate what characteristics of firms, and in special which competitive advantages of Brazilian firms contribute to a higher degree of internationalisation. Next we present our findings.

\section{Main Findings}

This work was driven by four main questions. The first one regarded the adequacy of the extension and quality of internationalisation of Brazilian firms to the country's level of economic development.

The second question sought to understand the role of technology in the internationalisation of Brazilian firms. In special, whether firms establish FDI with technology-seeking or technology-exploiting purposes. This question was especially important because recent waves of FDI from emerging countries (like China and Taiwan) have 
taken place at earlier development stages, when firms in thesis do not have strong competitive advantages to enter foreign markets. Firms from these countries are internationalising with the purpose of acquiring the competitive advantages that they lack. As innovation is the outcome of technological accumulation, we also investigate whether Brazilian multinationals are more innovative than non-internationalised firms.

The third question regards the specificity of Brazilian multinationals and to which extent it can be explained with existing theories and paradigms. Recently a growing number of studies have embraced this issue, some of them proposing alternative theories, others dealing with the existing ones with only small adjustments to better fit the new wave of emerging FDI.

Fourth, we ask about the role of governments- in the form of internationalisation policies but also in industrialisation and innovation policies - of emerging countries in the generation of national global players.

Here is what we got. Chapter 1 described the country's economic structure and industrialisation policies to investigate how they have shaped the patterns of competitiveness and international expansion of Brazilian firms. An important characteristic highlighted was the division of tasks between the state, domestic and foreign private sector, which led to a concentration of domestic investment in resource-rich and mature industries, while an important share of basic industry was taken by foreign investments that came to Brazil in the post-war period.

Chapter 1 also considered how policies are shaping the patterns of recent Chinese FDI. Similarly to developments in Korea in the 1970s and 1980s, the Chinese government is closely orienting the directions followed by national companies in their international expansion. In Brazil, policies to stimulate internationalisation are more recent and still modest, though early industrialisation policies have strongly determined the economic structure that the country maintains until today.

The speed with which firms from emerging countries are internationalising emphasises the role played by government policies in fostering the process. In cases like China, there is strong government stimulus for firms to become global. In other countries, like Korea, a specific set of industrialisation policies targeting strategic economic sectors have borne fruit, and Korea is today one of the most prominent examples of technological catching-up and development.

Chapter 1 answers two of the questions raised by the thesis. First, it concludes that policies do influence, to some extent, the successful internationalisation of firms from emerging markets. This influence comes from both specific internationalisation policies and (perhaps most importantly) industrial policies and stimuli for the development of competitive domestic industries.

Chapter 1 also helped us to conclude that the Brazilian multinationals of today are a reflection of the economic development path followed by the country in the past 50 years or so. Brazil is quite a peculiar country in terms of the size of its domestic market, of its abundant natural resources, which gives the country a lower degree of internationalisation if compared with countries like Chile and Argentina, which have a considerably smaller domestic market and therefore more internationalised firms (Ig- 
lesias and Veiga, 2004). For many years and to many firms, it simply did not make sense to abandon a market with such potential for growth, so many resources to explore. This is corroborated by the survey finding that one of the main reasons for firms not to invest abroad is the existence of more interesting business opportunities in the domestic market. Policies contributed a lot in making home the best market for business.

The intensification of globalization, felt by businesses in Brazil especially after the 1990s, have nonetheless changed this scenario, and increased global competition had reflexes in the domestic market as well. This shift in the competitive scenario was a main driver of the internationalisation of Brazilian firms, and can be considered a turning point.

This momentum in the internationalisation of Brazilian (and other Latin American countries) firms in the 1990s is what Cuervo-Cazurra (2008) calls "the transformation of location advantages". Structural reforms carried out in several developing countries produced a new competitive scenario for domestic firms and induced them to develop ownership advantages to operate in higher competitive environments (Cuervo-Cazurra, 2008: 149).

In other words, the Brazilian multinationals that emerged in the past decades are a consequence of the industrialization pattern, the structural reforms, the competitive level in the domestic market and are a good portrait of the country's current industrial dynamics.

Chapters 3, 4 and 5 helped us answer another question, regarding the role of technology and innovation to the internationalisation of Brazilian firms. The two empirical chapters dealt with the issue of technology and other competitive advantages of firms and how they influence the decision to invest in certain locations and also the commitment to foreign operations. The analysis revealed that firms identify in their technological capabilities a strong asset to operate in foreign markets. This is in line with the localised technological learning outlined by Sanjaya Lall in his early work on emerging multinationals (Lall, 1983). Brazilian multinationals still rely on competitive assets that are, to a great extent, location-bound, but this comes as no surprise, given the significant presence of multinationals in natural-resource sectors. Surprisingly, though, we found that Brazilian multinationals are now exploring their technological capabilities in developed locations.

Chapter 4 investigated how different levels of internationalisation relate to specific competitive advantages. The underlying question was whether the existence of technology- and innovation-related assets contribute to a deeper internationalisation of Brazilian firms, leading to more committed levels of engagement in foreign locations. The central purpose of this investigation was to find out to what extent the internationalisation process of Brazilian multinationals is gradual and increases as market knowledge and firm capabilities accumulate.

The results showed that technology-related assets and managerial capabilities are related to stronger levels of international commitment by Brazilian investors. Interestingly, advantages related to the possession of natural resources did not have a positive effect on internationalisation levels, which suggests that the internationalisation of 
firms from resource-intensive sectors may equally rely on more sophisticated capabilities.

In resume, technology is strongly identified as a key competitive advantage of Brazilian firms operating in foreign markets, even in more developed destinations. This is a paramount finding in a study of Brazilian multinationals: it reinforces the role of technological development and innovation in all industrial areas, even in sectors that are traditionally seen as resource-intensive.

Another question raised by this work was whether Brazilian FDI follows a new trend of investments from emerging countries (labelled as emerging FDI), or whether they are just old wine in a new bottle. In fact, many of the emerging multinationals that have gained momentum in the past decade are surprisingly fast and successful in their internationalisation. We can cite a few of these firms that have gained global reach at much faster pace than would have been expected by theories: Tata, Lenovo, Haier and a few others from China, India, Taiwan, Mexico are peculiar examples of a very fast, springboard internationalisation (Matthews, 2006; Luo and Tung, 2007).

Brazil has also produced its global champions, but one can hardly say that their internationalisation has been fast paced. The pattern of internationalisation of Brazilian firms is more cautious, gradual, usually started by exports and later making bolder movements.

Acquisitions have gained momentum among Brazilian investors in the past few years. However, internationalisation rarely starts with acquisitions. Acquisitions are used by firms that already have an international presence to intensify their presence and to access key assets in developed markets. They are not the first step towards internationalisation, and therefore do not contradict the gradual approach as an explanation for Brazilian FDI. In this sense, foreign investments from Brazilian firms are not similar to the internationalization movements of most Chinese firms, for instance, that are using internationalization as a springboard for the achievement of competitive assets.

Foreign direct investments from emerging economies have recently attracted the attention of international business scholars for their unprecedented speed in reaching overseas markets, and in particular their entry into developed markets as the USA and the EU. Much literature is devoted to this recent wave of emerging investment and its relation to traditional FDI. The Chinese case is of special interest because of the speed at which firms have reached key developed markets, acquiring top brands and gaining making presence among the top hundred multinationals from emerging markets.

The example of companies from other emerging markets, such as China and Taiwan, have shown that there is a growing interest by these firms in accessing key technological capabilities that are not available in their domestic environments. In this sense, technology-seeking FDI seems to have gained a new importance among firms from emerging markets; they internationalise without waiting for a strong technological maturity. What was once a competitive disadvantage has now become a driver of internationalisation.

Our conclusion is that the only common feature among emerging multinationals is their diversity: even firms from a same country can have quite different patterns of 
internationalisation. And, whereas Brazilian firms do fit into existing theories explaining FDI, there is another group of firms that have redesigned the significance of assetexploiting FDI.

\section{Main Contributions}

We expect this thesis to provide some contributions in the empirical and theoretical field, and also to provide some guidelines for future policies that aims to foster internationalization. The empirical contribution lies in the application of unprecedented micro-level data investigating determinants, modes, and also obstacles to the internationalization of Brazilian firms.

Another contribution was to combine micro- and macroeconomic perspectives to have a more comprehensive view of the process of internationalization of Brazilian firms. We did so by addressing the Investment Development Path, a derivative of the OLI paradigm developed by Dunning, this time focusing on the FDI from less developed countries. In this second framework, macroeconomic factors are taken into consideration along with the movements of inward and outward FDI. We consider this framework, though dealing with aspects that are not the main object of the thesis analysis (the firm), of great help to understand and explain how our object evolves over time in terms of capabilities and competitiveness.

We also hoped to contribute to the debate on the necessity to develop new theories to explain emerging multinationals. By investigating in depth the case of Brazilian firms and analysing it in the light of emerging countries, we conclude that this new trend - emerging multinationals - are quite a diverse subject, but which can make use of older theories, paradigms and models. In special, the Brazilian case proved to fit well in the framework that already explained the evolution of multinationals from developed countries, even though Brazilian firms do not follow a similar internationalization pattern.

This research can indicate a future path for policies aiming to foster the internationalisation of firms. A general conclusion taken from our analyses is that policies have a strong role in shaping and developing ownership advantages of firms. Structural reforms in Latin America, and in special in Brazil, have changed completely the competitive scenario for domestic firms. Many of them went bankrupt due to competition of imported products from low-wage countries. The ones that survived did so due to their capacity to respond to competition with innovative products or marketing strategies.

Indirect policies can have a strong impact on the internationalization of firms industrial and innovation policies having a special effect on the development of firm capabilities. Our findings indicate that Brazilian firms identify technology and innovation as strong capabilities linked to their foreign expansion, suggesting that policies in these areas will certainly contribute to the emergence of more global players from Brazil. 


\section{Limitations and future research}

It is worth stressing that the analyses undertaken by this thesis suffer the usual limitations of survey-based research. First of all, surveys usually capture the perception of respondents on the subject investigated. Despite our survey having targeted the top management of firms, their view of the matter may be biased in some way or another. To try to correct such problem, we gathered as much secondary information on the internationalization of Brazilian firms as possible. It seems that the story revealed by the survey is not very far from the general anecdotal findings of single case studies.

The size of the sample also posed a challenge to our analyses and unfortunately this was an irreversible problem, as it is quite hard to convince managers to take part in research that is not mandatory. Our models were mostly logistic due to the nature of data; the explanatory power of our regressions was around 25 percent, which is expected and accepted for this type of regressions.

Knowledge on the internationalization process of Brazilian firms could benefit a lot from data collected consistently over time, giving us the chance to analyse not only a portrait but the evolution of investments and how investments drivers, firms capabilities and impacts of internationalisation evolve over time. Also, the possibility to combine data from the Brazilian Innovation survey (PINTEC) with the database on Brazilian investments abroad (which has been done once but was not available for recent data) would bring a lot of additional information on the innovative behaviour of firms and how these relate to their internationalization process. The innovation survey would grant access to a time series data and would enable the analysis of the evolution of investments over the past decade.

Finally, we believe that further studies do have a fertile ground to investigate a number of issues that remain to be better explained. For instance, the subject of "bornglobal" firms is still understudied. What kind of born-global firms arise in Brazil? How is their internationalization process?

Also, interesting knowledge would come out of a survey that directly aimed to investigate the relationship of innovation and internationalisation. In special, how firms manage knowledge creation and assimilation at their subsidiaries around the world. This is an incipient but still understudied field in international business, regarding Brazilian firms. 


\section{REFERENCES}

A

Almeida, A. (Ed.) (2007), Internacionalização de empresas brasileiras - perspectivas e riscos. São Paulo, Editora Campus.

Almeida, M. (2009), Desafios da real política industrial brasileira do século XXI. Texto para discussão IPEA 1452, December.

Amann, Edmund (2009), Technology, Public Policy, and the Emergence of Brazilian Multinationals, in: Lael Brainard and Leonardo Martinez-Diaz (eds.), Brazil as an Economic Superpower? Understanding Brazil's Changing Role in the Global Economy. Washington, D.C.: Brookings Institution Press, 2009.

Araújo, L. and Serpa-Blundi, M. (2005), Adaptações estratégicas no ambiente internacional: o caso da Natura. NUPIN/COPPEAD working paper.

Arbaugh, J.B., Cox, L.W., and Camp, S.M. (2008), Why don't entrepreneurial firms internationalize more? Journal of Management Issues, Fall 2008.

Arbix, G., Salerno, M.S., and De Negri, J.A. (2004), Inovação, via internacionalização, faz bem para as exportações brasileiras. XVI Forum Nacional Economia do Conhecimento, Crescimento Sustentado e Inclusão Social. Rio de Janeiro, Brazil.

Arbix, G., Salerno, M.S., and De Negri, J.A. (2005), Internacionalização gera emprego de qualidade e melhora a competitividade das empresas brasileiras. In: De Negri, J. and Salerno, M. (Eds.) (2005), Inovação, padrões tecnológicos e desempenho das firmas industriais brasileiras. IPEA, Brasilia.

Aykut, D. and Goldstein, A. (2006), Developing country multinationals: South-South investment comes of age. OECD Development Centre Working Papers series, no. 257, Paris, OECD.

\section{B}

Baer, W.A. (2005), Economia brasileira. São Paulo, Ed. Nobel. 2nd edition.

Bals, L., Berry, H., and Hartmann, E. (2008), What is a "born global" firm? Paper presented at the 1st CBS Conference on Emerging FDI, Copenhagen, October 2008.

Barcellos, E. (2010), Internacionalização de empresas brasileiras: um estudo sobre a relação entre grau de internacionalização e desempenho financeiro. USP, São Paulo, dissertation presented to obtain the MPhil degree in Business. 
Barnard, H. (2008), Capability development and the geographic destination of outbound FDI by developing country firms. International Journal of Technology and Globalization, 4(1), pp. 39-55.

Barney, J. (1991), Firm resources and sustained competitive advantage. Journal of Management, 17(1), pp. 99-120.

Barreto, A. and Rocha, A. (2002), A expansão das fronteiras: brasileiros no exterior. In: Rocha (Ed.), As novas fronteiras: a multinacionalização das empresas brasileiras. Coleção Estudos Coppead.

Bartlett, C.A. and Ghoshal, S. (2000), Going global: Lessons from late movers. Harvard Business Review, 78, pp. 132-142.

BCG (Boston Consulting Group) (2009), The 2009 BCG Multilatinas - A Fresh Look at Latin America and How a New Breed of Competitors Are Reshaping the Business Landscape. Boston, The Boston Consulting Group, 38 pp.

Bedaque Jr, A., Vasconcellos, E., and Oliveira Jr, M. (2010), Inovação de valor na família de jatos Embraer 170/190. In: Oliveira Jr, M. (Ed.), Multinacionais brasileiras - internacionalização, inovação e estratégia global. São Paulo, Bookman.

Bellak, C. (2000), The investment development path of Austria. Vienna University of Economics, Department of Economics Working Paper Series, November 2000.

Blomström, M. and Kokko, A. (1998), Multinational corporations and spillovers. Journal of Economic Surveys, 12, pp. 247-277.

Bonaglia, F., Goldstein, A., and Mathews, J. (2006), Accelerated internationalisation by emerging multinationals: The case of the white goods sector. Mimeo, OECD Development Centre.

Brainard, L. and Martinez-Dias, L. (Eds.) (2009), Brazil as an Economic Superpower? Washington DC, The Brookings Institution.

Brennan. L. and Garvey, D. (2009), The role of knowledge in internationalization. Research in International Business and Finance, 23, pp. 120-133.

Bresser Pereira, L.C. (1984), Development and Crisis in Brazil. Westview Press, Boulder and London.

Bruni P. (2002), Petrobrás: estratégia e esforço tecnológico para alavancar competitividade. Boletim Infopetro Ano 3(3), pp. 5-6.

Buckley, P., Clegg, L.J., Cross, A.R, Liu, X., Voss, H., and Zheng, P. (2007), The determinants of Chinese outward direct investments. Journal of International Business Studies, 38, pp. 499-518. 
C

Cantwell, J. and Tolentino, P. (1990), Technological accumulation and third world multinationals. University of Reading Discussion Paper in International Investment and Business Studies, no. 139.

Carneiro, J., Rocha, A., and Silva, J. (2008), Challenging the Uppsala internationalization model: A contingent approach to the internationalization of services. Brazilian Administration Review, 5(2), art. 1, pp. 85-103, Apr./June 2008.

Carvalho, F. (2010), University-industry partnerships in the Brazilian industry: The use of external sources of knowledge for innovation. Paper presented at the 2011 BALAS Annual Conference, Santiago, Chile.

Carvalho, F., Duysters, G., and Costa, I. (2010), Understanding Brazilian FDI - an investigation on the relationship between internationalisation and economic structure. Int. J. Business Environment, 3(4), pp. 393-411.

Carvalho, F. and Goldstein, A. (2009), The 'making of' national giants: The international expansion of oil companies from Brazil and China. In: Dolfsma W., Duysters, G., and Costa, I. (Eds.), Multinationals and Emerging Economies: The Quest for Innovation and Sustainability. Edward Elgar, London.

Carvalho, F. (2012), An oil giant from the emerging world - Petrobrás. In: Looney, R. (ed.), Handbook of oil politics. London, Routledge.

Casanova, L. (2009), Global Latinas - Latin America's Emerging Multinationals. INSEAD, Palgrave/MacMillan.

Cassiolato, J., Lastres, H., Szaprio, M., and Vargas, M. (2001), Local systems of innovation in Brazil, development and transnational corporations: A preliminary assessment based on empirical results of a research project. Druid Summer Conference 2001. Available at http://www.druid.dk/uploads/tx_picturedb/ds2001-281.pdf

Castro, F. (2004), Foreign direct investment in a late industrializing country: The Portuguese IDP revisited. Faculdade de Economia, Universidade do Porto, CEMPRE Working Papers No. 147.

CEPAL (Commission Economica para America Latina y el Caribe) (2008), La inversión extranjera directa en America Latina y el Caribe. Documento Informativo. UN, Santiago, Chile.

CEPAL (2009), Foreign Investment in Latin America and Caribbean - 2008.

CEPAL (2011); O investimento estrangeiro direto na América Latina e Caribe. United Nations, Santiago, Chile.

Chang, H.-J. (2007), Bad Samaritans - The Guilty Secrets of Rich Nations and the Threat to Global Prosperity. London, Random House Business Books.

Chesnais, F. (1996), A mundialização do capital. São Paulo, Ed. Xamá. 
Chevarria, D. (2006), O investimento direto externo da Petrobrás: uma analise com base em vantagens específicas. Master's thesis, Unisinos, RS/Brazil.

Child, J. and Rodrigues, S. (2005), The internationalization of Chinese firms: A case for theoretical extension? Management and Organization Review 1(3), pp. 381-410.

Child, J. and Rodrigues, S. (2010), Padroes e motivos da internacionalização de empresas chinesas. In: Oliveira Jr, M. (Ed.), Multinacionais brasileiras - internacionalização, inovação e estratégia global. São Paulo, Bookman.

Chudnovsky, D., Kosacoff, B., and Lopez, A. (1999), Las multinacionales latinoamericanas: sus estrategias en un mundo globalizado. Buenos Aires, Fondo De Cultura Economica.

Cohen, M. and Levinthal, D. (1990), Absorptive capacity: A new perspective on learning and innovation. Administrative Science Quarterly, 35(1), pp. 128-152.

Consoni, F. (2004), PhD thesis presented at the Science \& Technology Policy Department, UNICAMP.

Costa, I. (2005), Technological learning, R\&D and foreign affiliates in Brazil. Proceedings of an UNCTAD Expert Meeting: Globalization of R\&D and Developing Countries. UN: New York and Geneva.

Cuervo-Cazurra, A. (2008), The multinationalization of developing country MNEs: The case of multilatinas. Journal of International Management 14, pp. 138-154.

$\mathrm{D}$

Dantas, E. and Bell, M. (2006), Latecomer firms and the development of knowledge networks: The case of Petrobrás in Brazil. Paper presented at the SPRU 40th Anniversary Conference on The Future of Science, Technology and Innovation Policy. Brighton, September 2006.

De Negri, J. and Salerno, M. (Eds.) (2005), Inovação, padrões tecnológicos e desempenho das firmas industriais brasileiras. IPEA, Brasilia.

DTI (2009), R\&D Scoreboard. Department for Innovation, Universities and Skills, UK. Accessed at www.innovation.gov.uk/rd_scoreboard

Dunning, J.H. (1981), Explaining the international direct investment position of countries: Towards a dynamic or developmental approach, Weltwirtschaftliches Archiv, 117, pp. 30-64.

Dunning, J. (1988a), The theory of international production. International Trade Journal 3(1), pp. 21-66.

Dunning, J. (1988b), Explaining International Production. London, Unwin Hyman.

Dunning, J. (1993), Multinational Enterprises and the Global Economy. AddisonWesley, London, first edition. 
Dunning, J.H. (1998), Location and the multinational enterprise: A neglected factor? Journal of International Business Studies, 29(1), pp. 45-66.

Dunning, J. (2001a), The eclectic (OLI) paradigm of international production: Past, present and future. International Journal of the Economics of Business, 8(2), pp. 173190.

Dunning, J. (2001b), The key literature on IB activities: 1960-2000. In: Rugman, A. and Brewer, T. (Eds.), The Oxford Handbook of International Business, pp. 36-68.

Dunning, J., Haesel, R., and Narula, R. (1997), Explaining the 'new' wave of outward FDI from developing countries: The case of Taiwan and Korea. MERIT Working Paper, Maastricht, The Netherlands.

Dunning, J., Kim, C., and Park, D. (2008), Old wine in new bottles: A comparison of emerging market TNCs today and developed country TNCs thirty years ago. In: Sauvant, K. (Ed.), The Rise of Transnational Corporations from Emerging Markets: Threat or Opportunity? Edward Elgar, Massachusetts.

Dunning, J. and Lundan, S. (2008), Multinational Enterprises and the Global Econo$m y$. London, Edward Elgar, second edition.

Dunning, J. and Narula, R. (1996), The investment development path revisited - some emerging issues. In: Dunning, J. and Narula, R. (Eds.), Foreign Direct Investment and Governments: Catalysts for Economic Change. London, Routledge, pp. 1-41.

Dunning, J.H., Van Hoesel, R., and Narula, R. (1997), Third world multinationals revisited: New developments and theoretical implications. In: Dunning, J. (Ed.), Globalization, Trade and Foreign Direct Investment. Oxford, Pergamon Press, pp. 255-286.

Duran, J. and Ubeda, F. (2001), The investment development path: A new empirical approach and some theoretical issues. Transnational Corporations, 10(2), pp. 1-34.

Duysters, G. and Hagedoorn, J. (2000), International technological collaborations: Implications for newly industrializing countries. In: Kim, L. and Nelson, R. (Eds.), Technology, Learning and Innovation: Experiences of Newly Industrializing Economies. Cambridge University Press.

\section{E}

Economist (2007), Land of promise. April 14.

Economist (2009), Brazil takes off. November 12.

Embraer (2010), Annual Report. Available at www.embraer.com.br 
FDC (Fundação Dom Cabral) (2008), Ranking das transacionais brasileiras - internacionalização segue crescendo, mas resultados ainda são limitados. Nova Lima, mimeo.

FDC and CPII (Fundação Dom Cabral and Columbia Center of International Investments) (2007), Brazil's multinationals take off - Release of the FDC-CPII ranking of Brazilian multinational enterprises. Press release, New York, University of Columbia.

FDC (2012), Ranking das Transnacionais Brasileiras 2011: crescimento e gestão sustentável no exterior. Caderno de Ideias 1215, Nova Lima, Brasil.

Ferraz, J. C., Kupfer, D., Iooty, M. (2004), Industrial Competitiveness in Brazil - ten years after economic liberalisation. Cepal Review, nr. 82, pp. 91-117.

Fleury, A. and Fleury, M. (2009), The core competences of Brazilian multinationals. Paper presented at the AIB Annual Meeting, San Diego, 2009.

Forsgren, M. (2001), The concept of learning in the Uppsala internationalization process model: A critical review. Uppsala School of Business Occasional Paper, 2001/01.

Franco, G. (1998), A inserção externa e o desenvolvimento. Revista de Economia Política 18(3), pp. 121-147.

Freeman, S., Hutchings, K., Lazaris, M., and Zyngier, S. (2010), A model of rapid knowledge development: The smaller born-global firm. International Business Review 19 , pp. 70-84.

Freeman, C. and Soete, L. (1997), The Economics of Industrial Innovation, 3rd Edition. MIT Press Books.

Furtado, A. (1997), A trajetória tecnológica da Petrobras na produção offshore. Textos para Discussão n. 18. Campinas: Departamento de Política Científica e Tecnológica (DPCT). Available at: http://geo25.ige.unicamp.br/site/publicacoes/dpct/Texto-18.doc

Furtado, A. and Freitas, A. (2000), The catch up strategy of Petrobrás through cooperative R\&D. Journal of Technology Transfer 25(1), pp. 23-36.

G

Gallina, R., Fleury, A., and Bulba, E. (2005), O processo de internacionalização de uma empresa brasileira no setor de autopeças: o caso da Sabó. XI Seminário LatinoAmericano de Gestion Tecnológica - ALTEC. Salvador, Brazil.

Gammeltoft, P., Barnard, H., Madhok, A. (2010), Emerging Multinationals, emerging theory: Macro- and micro-level perspectives. Journal of International Management 16(2010), pp. 95-101.

Goldstein, A. (2007), Multinational Companies from Emerging Economies: Composition, Conceptualization and Direction in the Global Economy. London, Palgrave. 
Goldstein, A. (2008), A Latin American global player goes to Asia: Embraer in China. International Journal of Technology and Globalization 4(1), pp. 56-69.

Goldstein, A. and Pusterla, F. (2008), Emerging economies multinationals: Specificities of the Brazilian and Chinese cases. CESPRI Working Paper, no. 223, Universitá Bocconi, Milano.

Gugler, P. and Boie, B. (2009), The mechanisms and drivers of Chinese foreign investments - the prominent role of the visible hand. Paper presented at the AIB Conference, San Diego, CA, June 2009.

$\mathrm{H}$

Hemais, C. and Hilal, A. (2004), Teorias, paradigm e tendências em negócios internacionais: de Hymer ao empreendedorismo. In: Hemais, C. (org.), O desafio dos mercados externos - teoria e prática na internacionalização da firma. Rio de Janeiro, Ed. Mauad, Vol I.

Hilal, A. and Hemais, C. (2003), O processo de internacionalização na ótica da escola nórdica: evidências empíricas em empresas brasileiras. Revista de Administração Contemporânea, 7(1), Jan./Mar, pp. 109-124.

I

IBGE (2007), Pesquisa de inovação tecnológica 2005. Rio de Janeiro, 2005.

Iglesias, R. and Veiga, P.M. (2002), Promoção de exportações via internacionalização das firmas de capital Brasileiro. In: BNDES, O desafio das Exportações.

Iglesias, R. and Veiga, P.M. (2004), Investimento das firmas brasileiras do exterior: algumas hipóteses e resultados de uma pesquisa entre exportadores. In: Hemais, C. (org.), $\mathrm{O}$ desafio dos mercados externos - teoria e prática na internacionalização da firma. Rio de Janeiro, Ed. Mauad, Vol. II.

$\mathrm{J}$

Johanson, J. and Vahlne, J.-E. (1977), The internationalization process of the firm - a model for knowledge development and increasing foreign market commitments. Journal of International Business Studies, 8, pp. 23-32.

Johanson, J. and Vahlne, J.-E. (2009), The Uppsala internationalization process model revisited: From liability of foreignness to liability of outsidership. Journal of International Business Studies, 40, pp. 1411-1431.

K

Kim, L. (1997), Imitation to Innovation: The Dynamics of Korea's Technological Learning. Boston, Harvard Business School Press. 
Kinoshita, Y. (2001), R\&D and technology spillovers through FDI: Innovation and absorptive capacity, CEPR Discussion Papers 2775, London.

$\mathrm{L}$

Lall, S. (Ed.) (1983). The New Multinationals: The Spread of Third World Enterprises. Chichester: John Wiley \& Sons.

Lall, S. (1992), Technological capabilities and development. World Development 20(2), pp. 165-186.

Lecraw, D.J. (1977), Direct investment by firms from less developed countries. $O x$ ford Economic Papers, 29(3), pp. 442-57.

Lee, J. and Slater, J. (2007), Dynamic capabilities, entrepreneurial rent-seeking and the investment development path: The case of Samsung. Journal of International Management, 13, pp. 241-257.

Li, P.P. (2007), Toward an integrated theory of multinational evolution: The evidence of Chinese multinational enterprises as latecomers. Journal of International Management 13, pp. 296-318.

Lopez, A. (1999), El caso brasileño. In: Fondo de Cultura Econômica (Ed.), Las multinacionales latino americanas: estratégias en un mundo globalizado, Buenos Aires.

Luo, Y. and Tung, R.L. (2007), International expansion of emerging market enterprises: A springboard perspective. Journal of International Business Studies, 38(4), pp. 481-498.

$\mathrm{M}$

Makino, S., Lau, C., and Yeh, R. (2002), Asset-exploitation versus asset-seeking: Implications for location choice of foreign direct investment from newly industrialized economies. Journal of International Business Studies, 33(3), pp. 403-421.

Makino, S. and Neupert, K. (2000), National culture, transaction costs, and the choice between joint venture and wholly owned subsidiaries. Journal of International Business Studies, 31(4), pp. 705-713.

Mathews, J.A. (2002). Dragon Multinationals - A New Model for Global Growth. Oxford University Press.

Mathews, J. (2006), Dragon multinationals: New players in $21^{\text {st }}$ century globalization. Asia Pacific Journal of Management, 23, pp. 5-27.

MDIC (Ministério do Desenvolvimento, Industria e Comércio) (2009), Termo de referência: internacionalização de empresas brasileiras. Brasilia, December 2009.

Mirza, H. and Giroud, A. (2005), Chinese outward foreign direct investment. Mimeo. 
Moreira, M.M. (1999), Estrangeiros em uma economia aberta: impactos recentes sobre a produtividade, a concentração e o comércio exterior. In: Giambiagi, F. and Moreira, M.M. (Eds.), A economia brasileira nos anos 90, Rio de Janeiro: BNDES.

\section{$\mathrm{N}$}

Narula, R. (1996), Multinational Investment and Economic Structure. London, Routledge.

Narula, R. (2010), Much ado about nothing, or sirens of a brave new world? MNE activity from developing countries and its significance for development. UNUMERIT Working paper no. 021.

Narula, R. and Dunning, J. (2000), Industrial development, globalization and multinational enterprises, new realities for developing countries. Oxford Development Studies, 28(2), pp. 141-167.

Natura (2010), Annual Report. Available at www.natura.net

Nelson, R. and Winter, S. (1982), An Evolutionary Theory of Economic Change. Harvard University Press, Cambridge, Massachusetts.

Neto, J.B.O. and Dalla Costa, A. (2006), A Petrobrás e a exploração de petróleo offshore no Brasil: um approach evolucionário. IE-UFPR Texto para Discussão no. 20.

\section{$\mathrm{O}$}

Oliveira Jr., Moacir (ed.) (2010), Multinacionais Brasileiras: internacionalização, inovação e estratégia global. Porto Alegre, ed. Bookman.

Ozawa, T. (1992), Foreign direct investment and economic development. Transnational Corporations, I(1), February, pp. 27-54.

$\mathrm{P}$

Penrose, E. (1959), The Theory of the Growth of the Firm. Oxford, UK: Basil Blackwell.

Petrobrás (2006), Annual Report. Available at: www.Petrobrás.com.br. Accessed in 2008.

Petrobrás (2008), Annual Report. Available at: www.Petrobrás.com.br. Accessed in 2008.

PFC Energy (2010), Energy 50 - annual ranking of the world's largest listed energy firms. Available at: www.pfcenergy.com/pfc50.aspx

PIB Magazine, (2010), “Uma expansão perfumada”. Ano IV, nr.11, ago-set 2010.

Porter (1990), The Competitive Advantage of Nations. Free Press, New York. 
Prochnik, V., Esteves, L., and Freitas, F. (2007), Internationalization and firm heterogeneity in the Brazilian industry. Paper presented at the $1^{\text {st }}$ MEIDE Conference, UNU-MERIT, Maastricht, The Netherlands, May 2007.

R

Ramamurti, R. and Singh, J. (Eds.) (2009), Emerging Multinationals in Emerging Markets. Cambridge, Cambridge University Press.

Ramsey, J. and Almeida, A. (Eds.) (2009), The Rise of Brazilian Multinationals: Making the Leap from Regional Heavyweights to True Multinationals. Rio de Janeiro, Ed. Campus Elsevier.

Rezende, S. F. L. (2010), Gradualismo e descontinuidade em processos de internacionalização. In: Oliveira Jr., Moacir (ed.) (2010), Multinacionais Brasileiras: internacionalização, inovação e estratégia global. Porto Alegre, ed. Bookman.

Rocha, A. (Ed.) (2002), As novas fronteiras: a multinacionalização das empresas brasileiras. Rio De Janeiro, Mauad Editora.

Rocha, A. (Ed.) (2003), A internacionalização das empresas brasileiras - estudos de gestão internacional. Coleção Estudos Coppead, Rio de Janeiro, ed. Mauad.

Rocha, A. and Arkader, R. (2002), Internacionalização e escolhas estratégicas na indústria de autopeças. In: Rocha, A. (Ed.), (2002), A internacionalização das empresas brasileiras - estudos de gestão internacional, pp. 143-168.

Rosa, P.R. and Rhoden, M.I.S. (2007), Internacionalização de uma empresa brasileira: estudo de caso. Paper presented at the $4^{\text {th }}$ Congresso do Instituto Franco-Brasileiro de Administração de Empreas (IFBAE). Porto Alegre, May.

Rugman, A. and Doh, J. (2008), Multinationals and Development. Yale University Press.

$\mathrm{S}$

Sachwald, F. (Ed.) (2001), Going Multinational: The Korean Experience of Direct Investment. London, Routledge.

Sarti, F. and Laplane, M. (2002), O investimento direto estrangeiro e a internacionalização da economia brasileira nos anos 1990. Economia e Sociedade 11(1), pp. 63-94.

Sauvant, K. (Ed.) 2008, The Rise of Transnational Corporations from Emerging Markets: Threat or Opportunity? London, Edward Elgar.

SOBEET (2007), Internacionalização das empresas brasileiras. Fórum de Lideres, São Paulo, Clio Editora. 
Tolentino, P.E. (1993), Technological Innovation and Third World Multinationals. London, Routledge.

Tolentino, P.E. (2000), Emergence and evolution of MNCs from Brazil. In: Tolentino, P.E. (Ed.), Multinational Corporations: Emergence and Evolution. London, Routledge, pp. 93-122.

Turolla, F. and Margarido, M. (2008), O investimento brasileiro direto no exterior segue Uppsala? Uma análise econométrica. Paper presented at the $8^{\text {th }}$ Simpósio de Excelência en Gestão e Tecnologia (SEGeT), Rio de Janeiro.

$\mathrm{U}$

UNCTAD (2005), Firms in developing countries rapidly expanding foreign investment, transnational activities. Press Release.

UNCTAD (2006), World investment report 2006: FDI from developing and transition economies.

UNCTAD (2007), World investment report 2007. Geneva.

UNCTAD (2008), World investment report 2008: Transnational corporations and the infrastructure challenge.

UNCTAD (2009), World Investment report 2009. Geneva.

\section{V}

Valor Econômico (2010), Valor multinacionais brasileiras - as mais internacionalizadas. Ano 3, no. 3, 92 pp.

van Agtmael, A. (2007), The Emerging Market Century: How a New Breed of WorldClass Companies is Overtaking the World. New York, Free Press.

Villela, A. (1983), Brazilian multinationals. In: Lall, S. (Ed.), The New Multinationals: The Spread of Third World Enterprises, pp. 220-249. Chichester: John Wiley \& Sons.

W

Wells, T.J. Jr (1983), Third World Multinationals. Cambridge MIT Press, Massachusetts.

World Bank (2007), World Development Indicators. Washington, The World Bank. 



\section{SAMENVATTING}

\section{WAAROVER WE HET HEBBEN ALS WE HET OVER BRAZILIAANSE MULTINATIONALS HEBBEN - Een onderzoek van Braziliaanse DBI's, de economische structuur, innovatie en de relatie ertussen.}

De directe buitenlandse investeringen van de opkomende economieën zijn in de periode van 1990 tot 2010 gestegen en hebben een groei gekend van 145 miljoen Amerikaanse dollar tot 3,1 miljard (UNCTAD, 2011). Wegens deze opmerkelijke groei krijgen ze enorm veel aandacht en een steeds groter aantal essays, boeken en tijdschriften hebben de intrigerende vragen op dit gebied behandeld, vooral over de aard en de patronen van zulke investeringen, hun determinanten en vergelijkingen met traditionele investeringen van ontwikkelde economieën.

Bij de discussie van opkomende multinationals zijn er twee belangrijke aspecten onderzocht door academici en beoefenaars: ten eerste of de bestaande theorieën de evolutie van DBI's van opkomende landen volledig kunnen verklaren en of ze uitgebreid of vervangen moeten worden. Ten tweede is er onderzoek gedaan naar de factoren die opkomende multinationals naar vreemde markten drijven en de belangrijkste competitieve activa waarop de internationalisatie steunt. Hoewel er voor definitieve conclusies nog altijd grondigere onderzoeken nodig zijn, kan er aangenomen worden dat deze nieuwe soort bedrijven een stap verder dan de bestaande theorieën vereist om volledig begrepen te worden. Aangezien de bedrijven ook het product van hun land van herkomst zijn, hebben ze hun eigenaardigheden. In die zin wordt er in deze scriptie naar gestreefd bij te dragen tot een beter begrip van Braziliaanse multinationals en hoe ze verschillen van en gelijken op traditionele en andere opkomende multinationals.

In de scriptie wordt de rol onderzocht van technologie en innovatie bij de internationalisatie van Braziliaanse bedrijven. Dat is een belangrijke vraag met betrekking tot opkomende multinationals, omdat ze bepaalt hoe de bestaande theorieën zulke investeringen of de noodzaak aan nieuwe theorieën die beter bij het geval passen, kunnen verklaren.

In hoofdstuk 1 wordt de macro-economische dimensie van DBI's geïntroduceerd. In het hoofdstuk worden de effecten van de macro-economische structuur op de buitenlandse investeringstendensen voor Braziliaanse bedrijven beoordeeld. Er wordt besproken hoe het vroege industrialisatie- en liberalisatiebeleid het patroon van DBI's van Brazilië heeft beïnvloed en daarom een grote rol heeft gespeeld bij de soort multinationals die er ontstaan. In het hoofdstuk wordt het gebruik van beleidsvormen in de vroege stadia van de internationalisatie besproken in landen zoals Korea, dat vandaag de dag een ontwikkelde economie is waarvan enkele nationale bedrijven een aanzienlijke internationale aanwezigheid hebben en er wordt ook gekeken naar hoe de 
Chinese beleidsvormen de Go Global-strategie gecultiveerd hebben. De rol van beleidsvormen bij het genereren van opkomende multinationals wordt besproken.

In het hoofdstuk wordt aangetoond dat de beleidsvormen in een bepaalde mate een invloed hebben op de succesvolle internationalisatie van bedrijven van opkomende markten. Deze invloed komt van zowel specifieke internationalisatiebeleidsvormen als (en misschien wel vooral) van industriële beleidsvormen en stimuli voor de ontwikkeling van competitieve nationale industrieën.

In hoofdstuk 1wordt ook getoond dat de hedendaagse Braziliaanse multinationals een weerspiegeling zijn van het economische ontwikkelingspad dat het land gevolgd heeft in de afgelopen 50 jaar of zo. Brazilië is nogal een uitzonderlijk land wegens de grootte van zijn thuismarkt en zijn overvloedige natuurlijke hulpbronnen, waardoor het land een lagere internationalisatiegraad heeft in vergelijking met landen zoals Chili en Argentinië, die een aanzienlijk kleinere thuismarkt hebben en daarom ook meer geïnternationaliseerde bedrijven (Iglesias en Veiga, 2004). Gedurende vele jaren en voor veel bedrijven maakte het gewoon geen zin om een markt met zulk groeipotentieel en zo veel te ontginnen bronnen de rug toe te keren. Dit wordt bevestigd door de enquête waaruit gebleken is dat een van de belangrijkste redenen waarom bedrijven niet in het buitenland investeren schuilt in het voor handen zijn van interessantere zakelijke opportuniteiten op de thuismarkt. De beleidsvormen hebben ertoe geleid dat de thuismarkt de beste markt voor zakendoen is geworden.

Nadat de database en de methodologie van het werk voorgelegd worden in hoofdstuk 2, wordt in hoofdstuk 3 de eerste empirische beoordeling van de Global Players-database gepresenteerd. We onderzoeken de rol die technologie speelt bij de internationalisatie van bedrijven. We bekijken of Braziliaans bedrijven internationaliseren om technologische activa te verkrijgen die niet toegankelijk zijn op de plaatselijke markt of of ze hun geaccumuleerde technologische capaciteiten in het buitenland exploiteren. We vestigen speciale aandacht op de Braziliaanse investeringen die gericht zijn op ontwikkelde landen en op hoe technologie gekoppeld is aan de keuze van de locatie voor investeringen. Uit de analyse blijkt dat bedrijven in hun technologische capaciteiten een sterk voordeel zien om actief te zijn in buitenlandse markten. Dit ligt in de lijn van het gelokaliseerde technologisch leren dat beschreven wordt door Sanjaya Lall in zijn vroege werk over opkomende multinationals (Lall, 1983). Braziliaanse multinationals zijn nog altijd afhankelijk van competitieve activa die in grote mate locatiegebonden zijn, maar dat is niet verrassend, gezien de beduidende aanwezigheid van multinationals in de natuurlijke hulpbronnensector. Het was dan ook verrassend om te zien dat Braziliaanse multinationals hun technologische capaciteiten nu verkennen op ontwikkelde locaties.

In hoofdstuk 4 wordt beoordeeld hoe de competitieve voordelen van Braziliaanse bedrijven een invloed hebben op hun niveau van internationalisatie, dat gemeten wordt als het niveau van het engagement van het bedrijf op de buitenlandse markt. In andere woorden evalueren we of de internationalisatie van Braziliaanse bedrijven uitgelegd kan worden als een gradueel, evoluerend proces, waarbij bedrijven algemene kennis en informatie over buitenlandse markten verzamelen alsook welke karakteristieken 
geassocieerd worden met elk niveau. Uit de resultaten blijkt dat aan technologie gerelateerde activa en bestuurlijke capaciteiten gekoppeld zijn aan hogere niveaus van internationaal engagement van Braziliaanse investeerders. Het valt op dat de voordelen die gekoppeld zijn aan het bezit van natuurlijke hulpbronnen geen positieve invloed hebben op de internationalisatieniveaus, wat suggereert dat de internationalisatie van bedrijven in hulpbronnenintensieve sectoren in gelijke mate afhankelijk kan zijn van meer gesofisticeerde capaciteiten.

Samengevat wordt technologie geïdentificeerd als een uiterst belangrijk voordeel van Braziliaanse bedrijven die actief zijn op buitenlandse markten, zelfs op meer ontwikkelde bestemmingen. Dit is een essentiële bevinding in het onderzoek van Braziliaanse multinationals: ze versterkt de rol van technologische ontwikkeling en innovatie in alle industriële takken, zelfs in sectoren die traditioneel beschouwd worden als hulpbronnenintensief.

In hoofdstuk 5 wordt de relatie behandeld tussen de internationalisatie van Braziliaanse bedrijven en hun innovatieve activiteiten. In dit hoofdstuk wordt een andere gegevensbron gebruikt, de Braziliaanse innovatie-enquête (PINTEC, IBGE) om de meest innovatieve sectoren te accentueren. Er wordt ook een klassement gegeven van de meest geïnternationaliseerde Braziliaanse bedrijven. We gebruiken deze gegevens om een relatie te suggereren tussen de twee fenomenen. Het hoofdstuk wordt afgesloten met het geval Petrobras. De rol van innovatie en technologische capaciteiten bij de ontwikkeling van een grote globale speler wordt er goed in geïllustreerd.

Een laatste conclusie van dit werk is dat het enige wat opkomende multinationals gemeen hebben hun diversiteit is: zelfs bedrijven van eenzelfde land kunnen sterk uiteenlopende internationalisatiepatronen hebben. En hoewel de bestaande theorieën over DBI's van toepassing zijn op Braziliaanse bedrijven, is er een andere groep bedrijven die het belang van het exploiteren van activa bij DBI's opnieuw ontworpen hebben. 



\section{Curriculum Vitae}

Flavia Pereira de Carvalho is a Brazilian national, born on May 21st, 1977. She graduated in Economics at Universidade Estadual de Campinas and achieved a MPhil in Science and Technology Policy at the same university. For several years she has worked in research, covering various subjects such as innovation, technology spillovers from MNCs in developing countries, internationalization of R\&D activities, among others. She joined UNU-MERIT in 2006 to work with the subject of internationalisation of Brazilian firms. Currently she teaches Economics and Sustainability at UNI-BH, in Belo Horizonte, Brazil and does research at Fundação Dom Cabral (FDC). Her current research involves understanding the occurrence of ecoinnovations in the Brazilian context, their main drivers and the role of policies to foster the development of clean-tech. 

UNITED NATIONS

UNIVERSITY

\section{UNU-MERIT}

\section{3}

\section{Anant Kamath}

Information Sharing through Informal Interaction in Low-Tech Clusters

\section{Flavia Pereira de Carvalho}

What we talk about when we talk about Brazilian Mulitantionals: an investigation on Brazilian FDI, economic structure, innovation and the relationship between them

\section{Jun Hou}

Complementarity in Innovation and Development: A Cross-country Comparison

\section{Rufin Baghana}

Impacts of Government Incentives to R\&D, Innovation and Productivity:

A Microeconometric Analysis of the Québec Case

\section{Lilia I. Stubrin}

High-Tech Activities in Emerging Countries: A Network perspective on the Argentinean biotech activity

2012

\section{Abdul Waheed}

Innovation Determinants and Innovation as a Determinant: Evidence from Developing Countries

\section{Bilal Mirza}

Energy Poverty and Rural Energy Markets in Pakistan

\section{Benjamin Engelstätter}

Enterprise Software and Video Games: An Empirical Analysis

\section{Fulvia Farinelli}

Natural Resources, Innovation and Export Growth: The Wine Industry in Chili and Argentina

\section{Rodolfo Lauterbach}

Innovation in Manufacturing: From

Product Variety and Labor Productivity Growth to Economic Development in Chile

\section{Kirsten Wiebe}

Quantitative Assessment of Sustainable Development and Growth in SubSaharan Africa.

\section{Julio Miguel Rosa}

Organizational Strategies, Firms'

Performance and Spatial Spillovers. The Canadian Case in Research and Development.

\section{Johannes Wilhelmus Marie Boels}

Joseph Schumpeter, honderd jaar economische ontwikkeling. Een historisch-theoretische beschouwing.

2011

\section{Daniel Vertesy}

Interrupted Innovation: Emerging economies in the structure of the global aerospace industry.

\section{Tina Saebi}

Successfully managing alliance portfolios: an alliance capability view.

\section{Nora Engel}

Tuberculosis in India - A case of innovation and control.

\section{Evans Mupela}

Connectivity and growth in Sub-Saharan Africa: The role of communication satellites

\section{Nantawan Kwanjai}

Cross cultural intelligence amid intricate cultural webs - A tale of the

UnDutchables in the land of 1002 smiles 


\section{Lina Sonne}

Innovation in Finance to Finance Innovation: Supporting pro-poor entrepreneur-based innovation

2010

\section{Fernando Santiago}

Human Resources Management Practices and Learning for Innovation in Developing Countries: Pharmaceutical Firms in Mexico

\section{Zakaria Babutsidze}

Essays on Economies with Heterogenous Interacting Consumers

\section{Bertha Vallejo}

Learning and Innovation Under Changing Market Conditions: The Auto Parts Industry in Mexico

\section{Donatus Ayitey}

Technical Change, Competitiveness and Poverty Reduction: A Study of the Ghanaian Apparel Industry

\section{Sergey Fillipov}

Multinational Subsidiary Evolution: Corporate Change in New EU Member States

\section{Asel Doranova}

Technology Transfer and Learning under the Kyoto regime; Exploring the Technological Impact of CDM projects in developing countries

\section{Alexis Habiyaremye}

From Primary Commodity Dependence to Diversification and Growth". "Absorptive Capacity and Technological Catch Up in Botswana and Mauritius".

\section{Yoseph Getachew}

The Role of Public Capital in Economic Development

\section{Sandra Leitner}

Embodied Technological Change and Patterns of Investment in Austrian Manufacturing

\section{Semih Akçomak}

The Impact of Social Capital on Economic and Social Outcomes

\section{Abraham Garcia}

The Role of Demand in Technical

Change

\section{Saurabh Arora}

Coherence in socio-technical systems: a network perspective on the innovation process

\section{8}

\section{Rutger Daems}

Medicines for the developing world

\section{Johannes Hanel}

Assessing Induced Technology Sombart's Understanding of Technical Change in the History of Economics

\section{Rifka Weehuizen}

Mental Capital: the economic significance of mental health

\section{Danielle Cloodt}

The relationship between $R \& D$ partnership formation, social embeddedness and innovative performance

\section{Sabine Fuss}

Sustainable Energy Development under Uncertainty

2007

\section{Tobias Kronenberg}

Reconciling Environmental Conservation with Economic Prosperity: The Feasibility of Double Dividends in the Short and Long Run 


\section{Viktoria Kravtsova}

Assessing the Impact of Foreign Direct Investment in Transition Economies

\section{Suhail Sultan}

The Competitive Advantage of Small and Medium Sized Enterprises: The Case of Jordan's Natural Stone Industry

2006

\section{Bulat Sanditov}

Essays on Social Learning and Imitation

\section{Mamata Parhi}

Dynamics of New Technology Diffusion: A Study of the Indian Automotive Industry

\section{Andreas Reinstaller}

Social structures and the innovation process: Their role in the demand of firms and consumers

\section{Rose Kiggundu}

Innovation systems and development : the journey of a Beleaguered Nile Perch Fishery in Uganda

\section{Thomas Pogue}

The Evolution of Research Collaboration in South African Gold Mining: 18861933

\section{Geoffrey Gachino}

Foreign Direct Investment, Spillovers and Innovation: The Case of Kenyan Manufacturing Industry

\section{0. Önder Nomaler}

Technological Change, International Trade and Growth - An Evolutionary, Multi-Agents-Based Modeling Approach

\section{5}

\section{Samia Satti Osman Mohamed-}

\section{Nour}

Change and Skill Development in the Arab Gulf Countries

\section{Elad Harison}

Intellectual Property Rights: Economics and Policy Analysis

\section{Daniel Dalohoun}

The relationship between $R \& D$ partnership formation, social embeddedness and innovative performance: a multi-level approach of social embeddedness

\section{Müge Ozman}

Networks, Organizations and Knowledge

\section{Bas Straathof}

Product variety and economic growth The counteracting effects of scale and idiosyncrasy

\section{Wilfred Schoenmakers}

Knowledge Flows between Multinational Companies: A Patent Data Analysis

\section{Myriam Cloodt}

Mergers and Acquisitions (M\&As) in High-Tech Industries: Measuring the Post-M\&A Innovative Performance of Companies

\section{4}

\section{Paola Criscuolo}

R\&D Internationalisation and Knowledge Transfer. Impact on MNEs and their Home Countries

\section{Maarten Verkerk}

Trust and Power on the Shop Floor

\section{Gottfried Leibbrandt}

Adoption, harmonization and succession of network technologies across countries

\section{Mark Sanders}

Skill Biased Technical change - Its Origins, the Interaction with the Labour Market and Policy Implications 


\section{Nadine Roijakkers}

Inter-firm cooperation in high-tech industries: a study of R\&D partnerships in pharmaceutical biotechnology

\section{Viki Sonntag}

Speed, Scale and Sustainability

\section{Masaru Yarime}

From End-of-Pipe Technology to Clean Technology

\section{Stéphane Malo}

The combinatorial Chemistry Revolution

- Sustaining a Superior Performance

Position through Technological Learning

2002

\section{Annelies Hogenbirk}

Determinants of Inward Foreign Direct Investment: the Case of the Netherlands

2001

\section{John Adeoti}

Technology Investment in Pollution Control in Sub-Saharan Africa: The Case of the Nigerian Manufacturing Industry

\section{Edward Huizenga}

Innovation Management: How

Frontrunners Stay Ahead. An Empirical

Study on Key Success Factors in the ICT sector

2000

\section{Machiel van Dijk}

Technological Change and the Dynamics of Industries. Theoretical Issues and Empirical evidence from Dutch Manufacturing

\section{Jan Cobbenhagen}

Managing Innovation at the Company Level: A Study on Non-Sector-Specific Success Factors

\section{Marjolein Caniëls}

Regional Growth Differentials: The Impact of Locally Bounded Knowledge Spillovers

1998

\section{Aldo Geuna}

Resource allocation and knowledge production: Studies in the economics of university research

1996

\section{Reinoud Joosten}

Dynamics, Equilibria, and Values

\section{Hugo Kruiniger}

Investment, R\&D, and the Financing

Decisions of the Firm

1995

\section{Hans van Meijl}

Endogenous Technological Change: The Case of Information Technology.

Theoretical Considerations and Empirical Results

\section{René Kemp}

Environmental Policy and Technical Change. A Comparison of the Technological Impact of Policy Instruments

\section{Rohini Acharya}

The Impact of New Technologies on Economic Growth and Trade. A Case Study of Biotechnology 


\section{Geert Duysters}

The Evolution of Complex Industrial Systems. The Dynamics of Major IT Sectors

\section{Marjan Groen}

Technology, Work and Organisation, A Study of the Nursing Process in Intensive Care Units

1994

\section{Huub Meijers}

On the Diffusion of Technologies in a Vintage Framework; Theoretical Considerations and Empirical Results

\section{Theon van Dijk}

The Limits of Patent Protection. Essays on the Economics of Intellectual Property Rights

\section{Hans Voordijk}

Naar Integrale Logistiek in

Bedrijfsketens, Ontwikkelingen in de

Bouw

1993

\section{Paul Diederen}

Technological Progress in Enterprises and Diffusion of Innovations. Theoretical Reflections and Empirical Evidence.

\section{Ben Dankbaar}

Economic Crisis and Institutional Change. The crisis of Fordism from the perspective of the automobile industry

\section{Hanno Roberts}

Accountability and Responsibility: The Influence of Organisation Design on Management Accounting

1992

\section{Bart Verspagen}

Uneven Growth Between Interdependent Economies. An Evolutionary View on Technology Gaps, Trade and Growth

\section{Sjoerd Romme}

A Self-organization Perspective on Strategy Formation

1989

\section{John Spangenberg}

Economies of Scale, and Atmosphere in Research Organisations

\section{8}

\section{John Hagedoorn}

Evolutionary and heterodox innovation analysis : a study of industrial and technological development in process control and information technology 